\title{
Notes on the Sapotaceae of Southern Africa.
}

\section{By}

\author{
A. D. J. Meeuse.
}

\section{INTRODUCTION.}

In view of the proposed "Flora of Southern Africa", the Sapotaceae of the area were studied. It soon became apparent that several South African species also occur in tropical Africa or are closely related to tropical species, and this necessitated the study of material from adjoining regions such as Angola, Rhodesia and Portuguese East Africa. Several species not recorded from the Union, but found in neighbouring areas are included in this treatment, either because they may be recorded later, or because they were interesting in connection with related South African forms.

This revision is mainly based on material from herbaria in Southern Africa. Several problems that could not be solved in this country were passed on to our officer stationed at Kew, Mr. B. de Winter. My thanks are due to Mr. de Winter, not only for his valuable assistance with taxonomical problems, such as comparing of type specimens and other material at Kew and in the British Museum (Nat. Hist.), but also for his kind help in obtaining abstracts of several publications which were not available here. Without his contribution many minor difficulties and doubtful points could never have been satisfactorily cleased up.

The material of the National Herbarium Pretoria, was studied and, in addition. material was kindly sent on loan by the following herbaria (abbreviations are, where possible, those of the latest Index Herbariorum by Lanjouw and Stafleu): BOL. COI, GRA, J, L, LM, NBG (including SAM), NH, NU, PRE (including TRV), SRGH; and Forestry Department Herbarium. Pretoria (SAFD).

\section{History of the Study of Sapotaceae in Southern Africa.}

The first comprehensive work, De Candolle's Prodromus Vol. 8 (1844) only mentions two species from Southern Africa, viz., Siderox\%lon inerme L. and Mimusops caffra E. Mey. ex A. DC. Until the publication of Engler's monograph of all the African Sapotaceae in his series "Monographien Afrikanischer Pflanzenfamilien und Gattungen ", Vol. 8 (1904) —cited in the following pages as "Mon. Sapot. Afr."the study of Sapotaceae in Southern Africa was restricted to occasional descriptions of new species such as by Sonder in Linnaea 23 (1850) and by N. E. Brown in Kew Bull. 1895.

The Sapotaceae of tropical Africa were treated by Baker in Flora of Tropical Africa 3 (1877), but only very few of the species mentioned extend into South Africa.

In 1906 the family was treated in Flora Capensis, Vol. 4 (1), by C. H. Wright, whose account was partly based on unpublished notes left by Harvey. This treatment added very little to Engler's monograph and is not critical, in fact, most descriptions are practically literal translations of those given by Engler. Phillips, in Genera S. Afr. Flow. Pl. ed. 1 (1926), recognised three genera, viz. Sideroxylon (with 2 species in S. Africa), Chrysophyllum (3 spec.) and Mimusops (ll species). In the second edition 
of the Genera (1951), Phillips maintains the same 3 genera with 2, 3, and 12 species respectively. As will be pointed out later, his conception of the Sapotaceous genera cannot be maintained and more genera have to be recognised if present trends are accepted. The late Father J. Gersiner, finally, treated the family in two papers which are rather superficial as far as systematics and nomenclature are concerned, but most valuable on account of important field-notes; cf. J. S. Afr. Bot. 12: 47-55 (1946), and 14: 171-174 (1948). Gerstner's work has clarified the status of Chrysophyllum wilmsii Engl. and of Mahea natalensis Pierre ( $=$ Mimusops natalensis Engl. non Schinz). He recognised 5 genera. The following Table gives a comparative analysis of the species mentioned in the more comprehensive publications and the present author's interpretation (Cf. Table I).

\section{Delimination of the genera,}

The genera of Sapotaceae are not very sharply defined and the modern monographers are inclined to " moderate splitting ", which trend is followed here. For a more detailed account of the history of the generic taxonomy and of the various systems of classification, see Baehni, Candollea 7: 394-508 (1938).

The most recent systems of classification are those published by Baehni (l.c.) and by Lam (Occ. Papers. Bern. P. Bishop Mus. Honolulu 14, no. 9: 137-141 (1938), and Rec. Trav. Bot. Néerl. 36: 524 (1939). Although these two systems are basically entirely different, these authors agree in several essential points and in the delimitation of most genera. The most important feature of the most recent classifications, as far as the $\mathrm{S}$. African representatives are concerned, is the segregation of the several genera from the large and heterogeneous genus Mimusops sensu Engler (1904), such as Manilkara, Murica, Lecomiedoxa, Baillonella and others.

In this revision many more genera are accepted than was done by Phillips in his "Genera", but it is considered preferable to follow modern monographers of the family rather than one general, and consequently unspecialized, reference work.

\section{FAMILY CHARACTERS.}

Trees often attaining a large size or sometimes shrubs, occasionally climbing, containing latex ducts in all parts (even the fruits). Leaves alternate, almost invariably petiolate, undivided and usually with entire margin, often more or less leathery; stipules often present but usually early deciduous, setaceous or linear-subulate. Flowers axillary but often on older branches or stems, generally solitary or fascicled, sessile or pedicelled, regular, almost invariably bisexual, usually small but often fragrant. Calyx consisting of one or two whorls of free or nearly free sepals, usually with a rusty-brown pubescence on the outside; sepals $2-5$, occasionally more, in each whorl, usually entire, often firm to coriaceous. Corolla gamopetalous, usually cream or white and almost invariably glabrous, consisting of a tube and one or two whorls of 2-5 or occasionally more lobes; the tube usually cylindric to campanulate, usually short; the lobes imbricate, entire or occasionally fringed, in several genera each lobe bearing two lateral petaloid appendages of various sizes, sometimes nearly as large as the lobe itself, sometimes much smaller. Alternipetalous staminodes as many as there are petals in one whorl, or fewer, or absent, varying from rather large and petaloid to small and scale-like, entire, or variously fringed, lobed or dissected, glabrous or hairy. Epipetalous staminodes sometimes present, but if so they are transformed, sterile or abortive stamens and often resemble the latter in shape. Stamens in one or two whorls (occasionally in more whorls, not in Southern Africa), as many per whorl as the number of corolla-lobes or twice as many or fewer, inserted in the mouth of the corolla-tube or sometimes lower down; filaments usually present but generally short; anthers 2-thecous; thecae usually extrorse, dehiscing with longitudinal slits. Ovary usually 
IABI 1.-THE SAPOTACHA OF SOUTHER AFRLA ICOMPARAIIVE ANALYSIS

\begin{tabular}{|c|c|c|c|c|c|c|}
\hline $\begin{array}{l}\text { Author. } \\
\text { Genus. }\end{array}$ & A.DC., Prodr. VIIII (1844). & Baker in Fl. Trop. Air. 1111 (1877). & 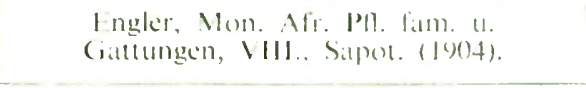 & C. H. Wright in H. Canp. IV, 1 (1) (6). & 1. Gierstner in J. S. Air. Bot. $12(1946)$ and $14(194)$ & Presemt revision. \\
\hline Sidteroxylon.......... & Silderoxylon inerme $\mathrm{L}$. & Sideroxylon diospyroites Baiker. & 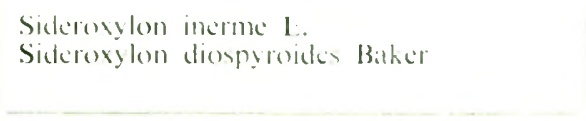 & 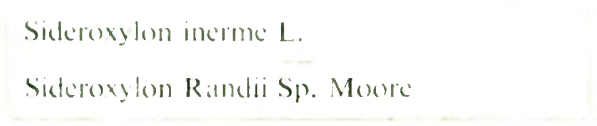 & $\begin{array}{l}\text { Sideronglons incrume L. } \\
\text { (Not mentioncd) }\end{array}$ & 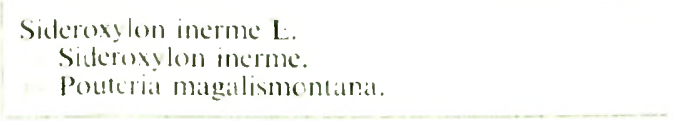 \\
\hline Chrysophy:lum...... & & Chrysophyllum magathmontanum Sord. & 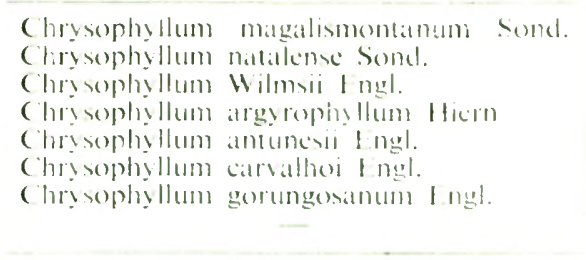 & 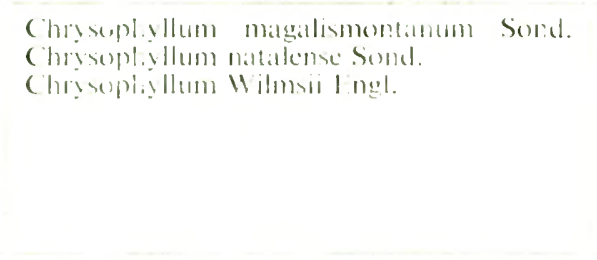 & 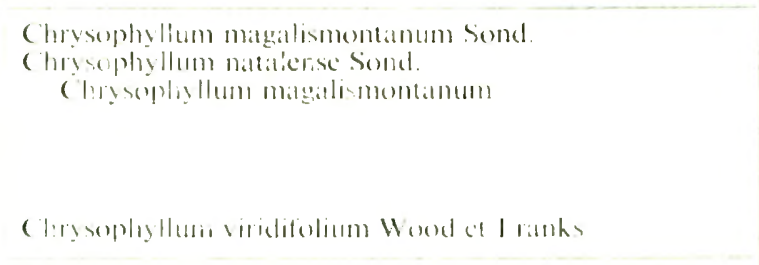 & 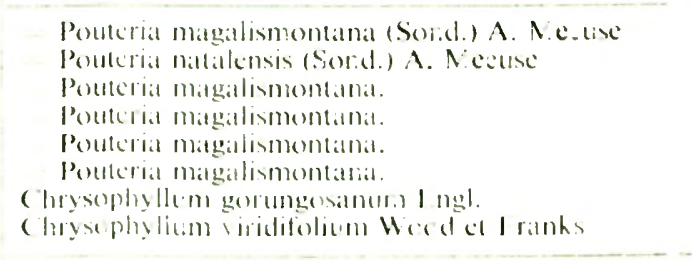 \\
\hline Poutcialia........... & & $\begin{array}{l}\text { (Under Chry sophlyllum) } \\
\text { (Sideroxylon brevipes Baker) }\end{array}$ & 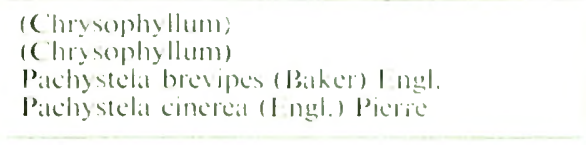 & 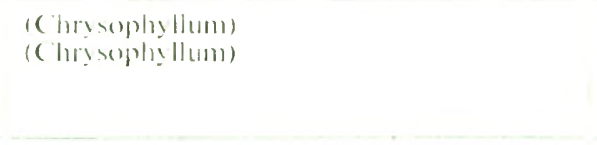 & 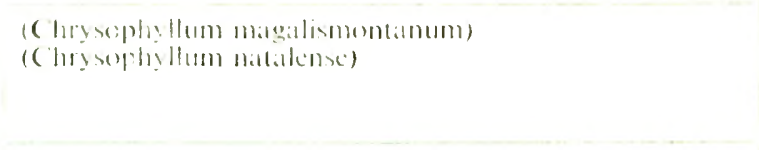 & 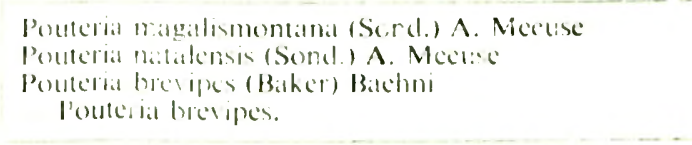 \\
\hline Vincentellia........... & & & & & & Vincentellit sapinini (De Wild). Brenan \\
\hline Mimusops... & Mimusops cillira E. Mey. ex A.DC. & $\begin{array}{l}\text { Minususps kirkii Baker } \\
\text { Mimusops milchisisial Baker }\end{array}$ & 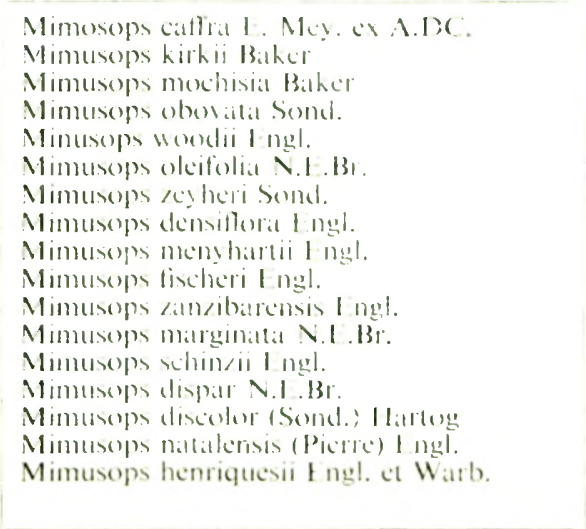 & 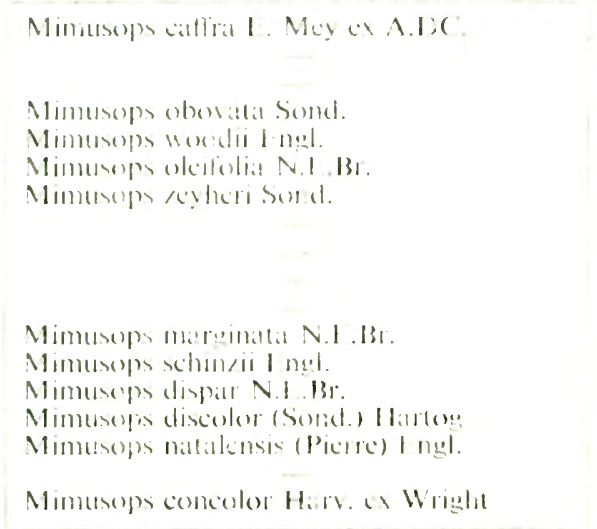 & 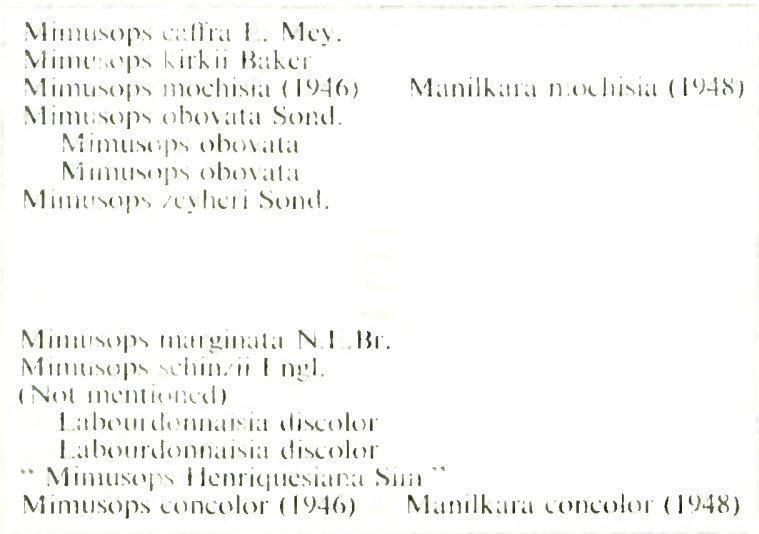 & 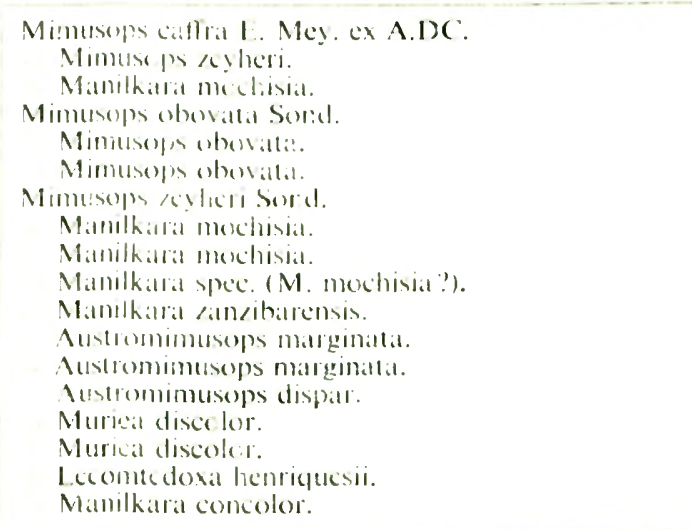 \\
\hline Austromimusop.... & & & 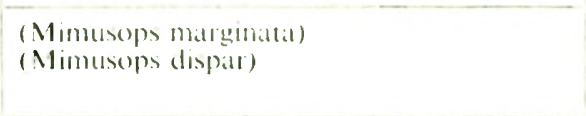 & 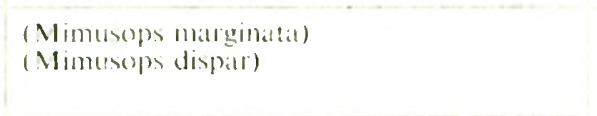 & (Mimusolos martginutia) & 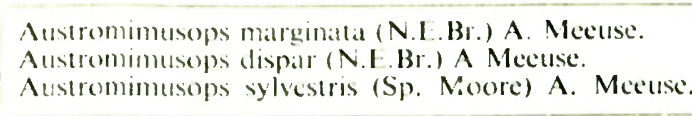 \\
\hline Manilkaia. & & (Mimusops mochisala Baktu, & $\begin{array}{l}\text { (Mimusops mochisia: } \\
\text { (Mimusops zaincibiritensis) }\end{array}$ & (Mimuseps concoler) & 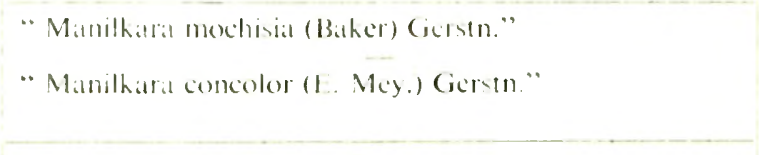 & 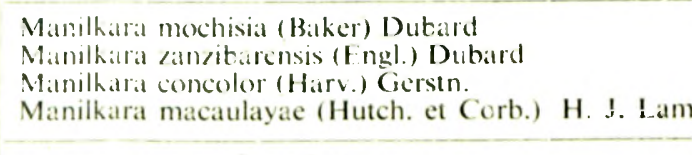 \\
\hline Muricit. & & & $\begin{array}{l}\text { (Mimusops discolor) } \\
\text { (Minususps natalensis) }\end{array}$ & (Mimusops discelor, Mimusups natalterisis) & Libourdommaisia discoler Sond. & Muricat discolor (Sond.) Hartog \\
\hline L.ecommoduxa...... & & & (Mimusops henriquesii) & & (Mimusops henriquestiana Sim) & 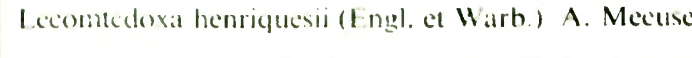 \\
\hline
\end{tabular}



5- to many-locular with a single ovule in each locule; style cylindric or more or less conical or subulate, ending in an acute or capitellate stigma; ovary superior, often rusty-pubescent. Fruit a berry with a usually thin outer layer and a juicy or mealy, rarely tough and leathery pulp in which the seeds are embedded. Seeds as many as there are ovules or fewer, compressed or tumid; testa either hard ("bony ") and in this case usually smooth and shiny, or leathery to crustaceous and in this case often dull, with an attachment area (cicatrix or "scar") containing the hilum; cicatrix basal or lateral, small and circular or large, sometimes covering about half the surface area of the seed, of a different texture (duller and rougher than the testa and usually thinner and softer); endosperm either copious and found on either side of the flat foliaceous cotyledons, or scanty to absent and in this case the cotyledons thick and fleshy.

An almost completely tropical family comprising over 600 described species in a number of genera which are very difficult to define, because there is hardly any other family of the Phanerogams where the characters integrate and overlap to such an extent. For this reason the number of " genera " varies from author to author, some recognising about a dozen, others up to 120 , but following present trends about 40 genera can be recognised. Another difficulty is that genera which appear to be rather sharply defined in one area may show intermediates in another region of the world and only a world-wide study can reveal the relationships. Several genera are already known to occur in more than one continent (Pouteria and Manilkara are circumtropical, Mimusops occurs in Africa and tropical Asia, Chrysophylhum is found in America and Africa and possibly occurs in Asia as well) and more similar links may be found.

\section{Key to the genera.}

As the genera of Sapotaceae are not very sharply defined. and both characters of the flower and the seed are used in their classification, the following key will not always lead direct to the proper genus if only flowers or only fruits are available, but the alternatives are indicated. Two characters used in the key need some explanation. In several genera the corolla-lobes occur in groups of three. The generally adopted conception is that each corolla-lobe, which is the central one of each group of three, bears two "lateral (or dorsal) appendages" which are often interpreted as stipules. Only Gilly [in Trop. Woods 73 (1934), p. 1-22] developed a different theory. viz., that in genera such as Mimusops and Manilkara the biseriate calyx of most authors represents the calyx and the corolla, the inner whorl being the true corolla. whereas the corolla of other authors is interpreted as an outer whorl of staminodes. It is not very likely that Gilly's views will be generally adopted, because there are genera having a monoseriate calyx and corolla-lobes with lateral appendages (Bumelia). The African genus Lecomtedoxa often shows sub-biseriate calyces and corolla-lobes with small lateral appendages and forms a link between the groups with biseriate calyces and (mostly) lateral appendages to the corolla-lobes (included by Lam in his subfamily Mimusopoideae) and the groups with mostly monoseriate calyces and usually without lateral appendages (Lam's Sideroxyloidea-Pouteriinae).

The other character used is the "scar" or cicatrix of the seed larea derasa of Baehni). The part of the testa by which the seed is or was attached to the inside of original loculum of the ovary is usually very distmet from the rest of the testa by a paler colour, a less smooth surface. a surrounding rim. location in a depression of the seed. etc. The shape and size of this area form a very good distinguishing character.

Flowers generally 5-merous; sepals in one whorl or at least never manifestly biseriate; lateral appendages to the corolla-lobes absent (only in Lecomtedoxa present):

Corolla-lobes without lateral appendages; flowers rather strictly 5-merous throughout:

Berry globose, 1-seeded; seed depressed-globose. bluntly 4- or 5-angled or somewhat ribbed, with a small circular cicatrix; alternipetalous staminodes always as many as the corolla-lobes and about as long, petaloid. usually triangular to lanceolate from a broad base; corolla-lobes not strongly reflexed... . 1. Sideroxylon. 
Berry usually ovoid to oblong: seed ellipsoid, ovoid or oblong, not angular or somewhat ribbed, with a lateral, usually long and sometimes very large scar:

Fruits usually 3-5-seeded; seeds laterally compressed with a hard, shiny bony testa and narrow linear scar; endosperm copious, cotyledons thin and foliaceous; alternipetalous staminodes $O$ (if fruit lacking and staminodes $\mathrm{O}$, sec also 3. Pouteria) ................. 2. Chrysophy/lum.

Fruits usually 1-seeded, sometimes 2-seeded; seeds usually not much compressed, with a thin, more crustaceous testa; scar linear or very large and occupying the ventral half of the seed; endosperm $\mathrm{O}$, cotyledons thick and fleshy; alternipetalous staminodes $1-5$, or absent:

Corolla-tube short but distinct; petals not strongly reflexed; filaments rather short and stoutish, stamens therefore not or but slightly exerted; ovary in flower not conspicuous.......... 3. Pouteria.

Corolla-tube very short to almost $\mathrm{O}$; petals completely reflexed; filaments long and slender, erect and hence stamens almost completely exerted; ovary exposed, comparatively large and conspicuous. 4. Vincentella.

Corolla-lobes with lateral appendages; whorls of flower 3-6-merous; alternipctalous staminodes present, as many as the corolla-lobes; fruit large $(-4 \mathrm{~cm}$. by $2-2.5 \mathrm{~cm}$.), l-seeded, with an oblong large lateral scar; seed without endo-

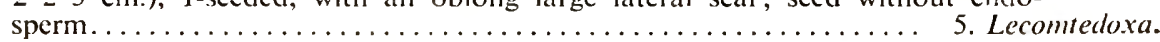

Flowers generally 3-4-merous, sepals always distinctly biseriate, corolla-lobes usually each with 2 petaloid lateral appendages, very rarely appendages small or $\mathrm{O}$ :

Flowers generally 4-merous; alternipetalous staminodes more or less lanceolate, entire

(except sometimes their tips), hairy outside; lateral appendages of the corolla-

lobes always well-developed:

Seed ellipsoid, not or but slightly laterally compressed, with a pergamaceous or crustaceous, not very shiny or quite dull testa and a large scar occupying most of the ventral half of the seed; endosperm $O$, cotyledons thick and fleshy; leaves distinctly crowded at the ends of the branches, usually not coriaceous nor shiny, with a fine usually conspicuous reticulate nervation; flowers in lower leaf-axils, often pendulous; ovules not basally attached 6. Austromimusops.

Seeds laterally flattened with a hard and shiny testa and a basal or sub-basal circular scar; endosperm present; cotyledons flat; leaves not distinctly crowded at the ends of the branches, usually more or less coriaceous, shiny on upper surface, the nervation usually not finely reticulate; flowers in the leaf-axils or sometimes also on naked branches; ovules basally attached....... 7. Mimusops.

Flowers generally 3-merous; alternipetalous staminodes various, entire or more or less divided, lobed, lacerated or fimbriate, glabrous, or absent and stamens twice as many as there are corolla-lobes (i.e., usually 12); rarely some or all stamens sterile and resembling staminodes; seed with endosperm and flat, foliaceous cotyledons:

Stamens as many as there are corolla-lobes (i.e., usually 6), alternating with as many or nearly as many alternipetalous staminodes; in the South African species corolla-lobes always with well-developed, lateral appendages and testa

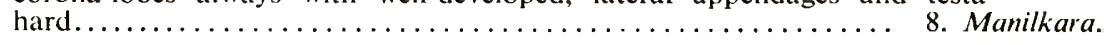

Stamens twice as many as there are corolla-lobes (i.e. usually 12); alternipetalous staminodes $O$, but occasionally some or all the stamens abortive and reduced to sterile staminode-like organs (in the latter case the normally present, lateral appendages to the corolla-lobes small or occasionally $\mathbf{O}$ ); testa rather thin, crustaceous and brittle when dry................... 9uriea

\section{SIDEROXYLON}

L., Gen. Pl. ed. 5, 89 (1754); Roem. et Schult., Syst. 4: 45 (1819); Endl., Gen. 739 (1837); Harvey, Gen. S. Afr. Plants 224 (1838); A.DC., Prodr. 8: 177 (1844), pro parte; Benth. et Hook. f., Gen. Pl. 2, 2: 655 (1876), pro parte; Baker in Oliv., Fl. Trop. Afr. 3: 503 (1877), pro parte; Engler in Engler-Prantl, Natürl. Pflanzenfam. 4, 1: 143 (1890), pro parte, and Mon. Sapot. Afr. 25 (1904), pro parte; Harvey ex Wright in Dyer, Fl. Cap. 4, 1: 142 (1906); Baehni in Candollea 7: 49 (1938), pro parte; H. J. Lam in Rec. Trav. Bot. Néerl. 36: 521 (1939); Phillips, Gen. S. Afr. Fl. Plants, ed. 2, 567 (1951). 
Calvaria Comm. sensu Dubard in Ann. Mus. Col. Marseille 20: 84 (1912); H. J. Lam in Occ. Papers Bern. P. Bishop Mus. Honolulu 14. no. 9: 138-139 (1938); Adamson in Adamson and Salter, Fl. Cape Penins. 667 (1950).

Type Species: Sideroxylon inerme L. (see discussion below).

Trees or shrubs. Flowers normally 5-merous throughout, all whorls single. Corolla-lobes without lateral appendages Alternipetalous staminodes petaloid, with a broad base. Ovules basally attached. Berry l-seeded. Seed depressed-globose, usually more or less 4- or 5-angled and somewhat ribbed; scar small. circular, situated in a basal depression of the seed; testa thick and bony; endosperm copious; cotyledons thin, foliaceous; embryo in the type species horizontal.

There has been a considerable amount of disagreement as regards the delimitation of the genus. Basing the genera of Sapotaceae almost exclusively on the structure of the flowers Bentham and Hooker and Engler included many forms with the flower pattern: sepals 5 . petals 5 without lateral appendages, alternipetalous staminodes 5, stamens 5, ovarium 5-loculated. in one lage genus Sideroxylon which is certainly not homogeneous. Pierre, and later Dubard [see Ann. Mus. Col. Marseille 20 (1912)]. using other characters apart from the floral structure, (e.g. the seeds) came to the conclusion that only a few species had to be retained in Sideroxylon. excluding, for instance. all forms which do not possess a basal scar. Unfortunately, Dubard placed the type species $S$. inerme L. in the genus Calvaria Comm. emend. Dub., as distinct from Sideroxylon L. sensu Dub. (in which he includes forms with a basal scar but not with a horizontal embryo as in Calvaria sensu Dub.).

The generic description agrees in principle with the delimination of the genus as understood by Baehni (op. cit.). Baehni mentions Sideroxylon inerme as the type species, but his description of the genus contains an error; the berry is said to be 4seeded. This is obviously a misprint or an oversight, because he clearly agrees with Dubard's ideas although he points out that Dubard erred when he took up the name Calvaria. Baehni is also inclined to include Dubard"s genus "Sideroxylon" (Dub.. op. cit., p. 81): “Nous adoptons l'idée de Dubard qui consiste à resteindre le genre aux seules espèces à cicatrice basilaire, mais nous y réintégrons cependant les Calvaria sensu Dubard "(Baehni, op. cit., p. 492). This seems to be reasonable, because Dubard"s genus Calvaria (=Sideroxylon sensu str.) and his genus Sideroxylon (=Mastichodendron Jacq.) differ only in the position of the embryo. Under this delimitation the genus includes a few species in America, probably only two in Africa and a few in Asia.

As regards the fixation of $S$. inerme as the type species, Linné mentioned two species in Sp. Pl. ed. 1, viz. S. inerme and S. spinosum. Both are properly defined and have never been confused with any other species. $S$. spinosum was placed in the monotypic genus Argania by Roemer and Schultes (Syst. Veg. 4: 46) as Argania Sideroxylon R. et S. [= Argania spinosa (L.) Skeels], leaving S. inerme L. as the only species in Sideroxylon and thus typifying it.

Sideroxylon inerme L., Sp. Pl. ed. 1: 192 (1753); Burm. f., Prodr. Fl. Cap. 6 (1768); Drege, Zw. Pflanzeng. Doc. 144, 153 (1843); A. DC. in DC.. Prodr. 8: 182 (1844); Wood. Natal Pl. 4, 1: pl. 314 (1903) Engl., Mon. Sap. Afr. 27, t.8 fig. B (1904), incl. var. schlechteri Engl.; Wright in Dyer, Fl. Cap. 4. 1: 438 (1906): Sim, For. Fl. Cape Col. 252, pl. 295 (1907); Marloth, Fl. S. Afr. 3: 36 pl. 10 (1932); Gerstner in J. S. Afr. Bot. 12: 47, fig. 1 (1946). S. cinereum Lamk., Encycl. $1: 244$, (1789), partim; Drege, op. cit., 222. S. diospyroides Baker in Oliv., Fl. Trop. Afr. 3: 502 (1877); Engler, op. cit. 27, t. 27, fig. A.

Myrsine querimbensis Klotzsch in Peters, Reise Mossamb., Bot. 185 (1862). 
Calvaria inermis (L.) Dubard in Ann. Mus. Col. Marseille 20: 86 (1912), incl. var. zanzibarensis Pierre ex Dub.; Adamson in Adams, and Salter, Fl. Cape Penins, 667 (1950). C. diospyroides (Baker) Dub., op cit. 87.

A shrub or small tree, up to $8 \mathrm{~m}$. occasionally $10-20 \mathrm{~m}$. high, but usually branched from the base and not forming a clean bole. Innovations reddish-brown tomentose. Leaves in vivo dark green and shiny above, paler below. often drying a peculiar dull greyish-green colour above, pale greyish brown beneath, occasionally (and especially the younger ones) drying dark olive-green above and reddish beneath, usually quite glabrous (except when very young), but occasionally with irregular chocolate-coloured, often powdery, patches of adpressed hairs; blade usually elliptic to obovate-oblong. more rarely (ob-)ovate, ovate-lanceolate, obovate-spathulate or (ob)lanceolate, 4-9 $(-12) \mathrm{cm}$. long and $2-4(-5) \mathrm{cm}$. wide, with subrellexed edges, obtuse (sometimes emarginate or retuse), its base acute or subacute, sometimes distinctly cuneate, always more or less decurrent on the petiole; midrib prominent beneath, secundary nerves 7-10 on either side, thin, more or less immersed and not very conspicuous; tertiary nerves not to hardly distinguishable from the fine reticulate nervations, the latter in older (dried) leaves often inconspicuous, but quite distinct in younger ones; petiole rather stout, often thickened towards the base, at first rusty-tomentose but soon quite glabrous, at least near the top distinctly winged by decurrent leaf, 6-10 (-15) mm. long. Flowers disagreeably scented, in few to many-flowered and sometimes very dense fascicles, occasionally (a few) flowers solitary, in the axils of the lower leaves on the branches, sometimes also on the naked branches just below the leaves, often raised on short warts. Bracts minute, deciduous, rufo-tomentose. Pedicels rather thick, slightly and gradually broadening towards the top. not very abruptly passing into the calyx, 2-12 $\mathrm{mm}$. long, sparingly whitish-pubescent, in fruit hardly lengthening but becoming much stouter, $1-1 \frac{1}{4} \mathrm{~mm}$. thick and often glabrescent. Caly $\times 2-2 \frac{1}{2} \mathrm{~mm}$. long, the lobes about as long as the calyx-tube, broadly ovate, subacute, erect, entire, ciliate, with a paler edge when dry, finely and sparingly whitish-pubescent, in fruit adpressed, scarcely accrescent. Corolla greenish-white, about twice as long as the calyx-lobes, rotate, up to about $5 \mathrm{~mm}$. across; tube short, lobes usually longer than the tube, ovate, entire, obtuse, glabrous. Stamens inserted in the throat of the corolla tube, longer than the corolla lobes. Alternipetalous staminodes ovate-lanceolate to oblong or oblong-lanceolate, as long as or slightly shorter than the corolla lobes, but always less wide than the latter, usually more or less distinctly incised, serrate, lacerate, dentate, crenulate or with a wavy edge, acute, acuminate or obtuse, sometimes tri- or multi-dentate at the apex. Ovary conical-semi-ovoid, covered with rather long adpressed white hairs (except in a zone near the base), usually 5-celled but occasionally 3, 4- or 6-celled; style about the same length as the ovary. glabrous. Berry black, globose, smooth, up to $12 \mathrm{~mm}$. in diam. when fresh, when dry up to $10 \mathrm{~mm}$. in diam. and wrinkled, usually crowned with the short persistent style; pulp purple or purplish-green, with white viscid juice; the latex long remaining sticky in dried specimens. Seed black when fresh but drying a shiny yellowish brown, usually depressed semi-globose or ellipsoid, rarely higher than broad, usually more or less disctinctly 4- or 5-angled and 5-ribbed, sometimes indistinctly lobed, 6-8 $\mathrm{mm}$. long, 5-7 $\mathrm{mm}$. wide and 5-8 $\frac{1}{2} \mathrm{~mm}$. high rarely up to $9 \frac{1}{2} \times 8 \times 7 \frac{1}{2} \mathrm{~mm}$., with several (4 or sometimes more) more or less distinct grooves which are most conspicuous near the scar, and with 2-4 small impressions between the grooves close to the scar.

Cape Province.--Cape Peninsula: Marloth 584; Chapmans' Bay, Wolley Dod 3444 (BOL); Gordon's Bay, Gerstner 6144; Witsand, Smuts 1190. Caledon: Onrust Riv., Schlechter 10396. Bredasdorp: Bredasdorp, Smith 2587. Riversdale: Riversdale, Muir 148; Marloth 3536. Mossel Bay: leg. Town Clerk, Mossel Bay (specimen of the "Post Office Tree", declared a national monument, PRE herb. no. 28382). Knysna: Kapp 100; Fourcade 623 (BOL). Humansdorp: Phillips 3328; Klipdrift, 
Thode 2490 (PRE). Uitenhage: Alexander; Ecklon or Ecklon \& Zeyher (L); Ecklon \& Zeyher (GRA). Zeyher 17 (BOL); Zwartkopsrivier, Drege (L). Port Elizabeth: Redhouse, Mogg 4672 (PRE). Alexandria: Kariega. White 101 (GRA). Bathurst: Karouga Mouth, Britten 2350; Kowie and Pt. Alfred. Tyson s.n.; Britten 1885; Barker 2106. Albany: near Riebeeck East, Dyer 3321. Alice: Acocks 8987. Fort Beaufort: Story 1698. Stutterheim: Fort Cunynghame. Galpin 2468. King Williams Town: near King Williams Town, Comins 1031. East London: Smith 3816. Galpin 9843. Queenstown: near Queenstown. Galpin 8137. Komgha: Komgha, Flanagan 777: Kei Mouth, Flanagan 770. Kentani: Pegler 882. Port St. Johns: Galpin 11465. Cape without precise locality: specimen in Linnaean herbarium (photo in PRE), lectotype!

Natal.-Port Shepstone: Paddock, Oribi Gorge, McClean 267. Umzinto: Umkomaas, Pennington s.n. (NH no. 27756). Pinetown: Isipingo, Ward 570; Amanzimtoti: Kotze $452=$ FD Herb. 6875. Durban: near Durban. Wood 8707, 9578. Inanda: Tongaat Beach, Hillary 375 (NU). Lower Tugela: Darnall, Schmidt 41 (NH). Estcourt: Mooi River, Wood 6306. Weenen: between Weenen and Estcourt. Edwards 702. Msinga: near Tugela Ferry, Edwards 935. Mtunzini: Lain 623 (NH). Eshowe: Eshowe, Gerstner 1945 (NH). Habisa: False Bay. Gerstner 4818; Hluhluwe Game Reserve, Ward 1895. Ngotshe: near Magut, Acocks 13023; Codd 1961; West 2117.

Swaziland: on road to Komatipoort. Pole Evans 3463, 3467; near Stegi. Compton 26017; Rodin 4548, Usutu River, Miller S249.

Transvaal.-Nelspruit: Kruger National Park, near Pretorius Kop. Codd 6029; near Skukuza, Codd 5735. Barberton: Komatipoort. Rogers 20800; Codd 7776.

Portuguese E. Africa.-Sul do Save, Maputo, Hornhy 2668; Myre \& Balsinhas 607; between Umeluzi and Porto Henrique, Myre \& Carralho 92; Lourenço Marques. Schlechter 11710 (L. GRA, PRE, BOL: type no. of S. inerme L. var. Schlechteri Engl.): Borle 418; Bremekamp LM60a; Rodin 4173; Porto do Oura Beach. Gomes e Sousa 3926; Inhaka Island, Mogg sm., Mrs. Moss s.n.; Goba Mts, Tóre 6490: NuanetsiLimpopo Valley nr. Transvaal Border, Smuts P. 322. Guifa, Pedro \& Pedrogão 2135: between Muianga and Macia: Pedrogão 1443: near Chibuto, Pedro \& Pedrogão 1534: between Su Larrime and Ganda, Pedro \& Pedrogão 1890. Sabi River, near Meringua. Chase 2535. Niassa: near Cabo Delgado, Barbosa 2167 (LM).

Tanganyika Terr.-Morogoro Distr.: Kwaba, Wigg 974. Kisarawe distr.: Kisiju, Semsei 1377, Paulo 153.

KenYa Col.-Greater Kiboko River: Jarrett 518.

Mr. B. de Winter kindly examined the Linnaean Herbarium in London and informed me that there is only one specimen which is undoubtedly Sideroxylon inerme and must be considered to be the lectotype (Mr. de Winter matched it with a specimen Hutton s.n. from Fish River Heights, Albany, C.P.). S. inerme was one of the first Sapotaceae known in Europe and one of the oldest plates is found in Burman. Dec. Rar. Afr. (1738), p. 238 , t. 94 , fig. 2. The seed is unmistakable and Burman also mentions: “ . . in Cod. Wits. . . latescens . . vocatur".

This plant was described from South Africa by Linné and, in its typical form with comparatively narrow leaves and long pedicels, is found from the Cape Peninsula eastwards along the coast to Natal and extends into Portuguese East Africa. Baker 
described a species $S$. diospyroides, from Zanguebar in tropical East Africa, which has smaller flowers, short pedicels and obovate-cuneate leaves. Engler remarked on the similarity between the two, but mentioned the following differences:--

(1) pedicels of $S$. diopyroides shorter than in $S$. inerme,

(2) staminodes broader and acuminate in $S$. diospyroides, narrower and not acuminate in $S$. inerme.

(3) seed of diospyroides smaller than that of $S$. inerme.

Acuminate and broad staminodes and small seeds are, however, also found in specimens of $S$. inerme from the Cape and $\mathrm{Mr}$. de Winter, who studied the material at Kew, informed me that the only difference he could find was in the length of the pedicels.

The material from Portuguese East Africa is very often intermediate and includes forms with narrow leaves, short pedicels and small fruits and forms with broad leaves (as in typical $S$. diospyroides) with large seeds, etc. These intermediate specimens link up the two forms so that in my opinion. $S$. diospyroides only represents a minor geographical variant of $S$. inerme and is not even worthy of varietal rank.

Doubtful localities are: "Near Pretoria ". McLea in herb. Bolus no. 5698 (BOL, PRE), because this species has never since been found near Pretoria, and "Johannesburg: Melville ": Moss I5906 (J). Dr. J. B. Gilliland, formerly of the Dept. of Botany, Witwatersrand University, has kindly informed me that there is no trace of the species anywhere in the Witwatersrand area.

Excluded species:

Sideroxylon argenteum Thunb., Prodr. FI. Cap. $36(1794)=$ Rhus thumbergii Hook. = Heeria argentea (Thbg.) Meissn. [1. 335)

Sidero.rylon randii S. Moore $=$ Pouteria magalismontana (Sond.) A Meeuse (see

Sideroxylon dentatum Burm. f., Prodr. Fl. Cap. $6(1768)=$ Curtisia dentata (Burm. f.) C. A. Smith in J. S. Afr. Forestry Assoc. 20: 34, 50 (1951). This species was legitimately published, as Burman based it on the plate and description of his father's Sideroxylon foliis acuminatis dentatis, fructu monospermo flavo |Burm., Dec. Rar. Afr. Plant. (1738), p. 235, t. 82]. The plant in question is undoubtedly the same as published by Aiton [Hort. Kew ed. 1 (1789), p. 162] under the name Curtisia faginea. Not only are the elder Burman's plate and description quite adequate to recognise the species, but he also mentioned the name "Assagay-Boom" used by the Dutch at the Cape, under which name it is still known. Moreover, Aiton, I.c. quotes "Burm. Afr. p. 235 t. 82 " and the phrase name "Sideroxyion foliis acuminatis etc.", and Harvey in Harv. and Sond., Fl. Cap. 2: 570. sub Curtisea faginea Ait., also mentioned "Burm. Dec. Afr. p. 235, t. $82 "$. This identity had already been recognised by the late C. A. Smith, who did not give any reasons, however, whei he proposed the above-mentioned change of narne.

\section{CHRYSOPHYLLUM}

L., Gen. Pl. ed. 5, 89 (1754); A. DC. in DC., Prodr. 8: 56 (1844); Benth. et Hook. f., Gen. Pl. 2: 653 (1876); Baker in Oliv., Fl. Trop. Afr. 3: 498 (1877), ex parte: Engler in Engler \& Prantl., Nat. Pflanzenfam. ed. 1, 4. 1: 147 (1890), pro majore parte, in Nachträge 278 (1897), and Mon. Sap. afr. 38 (1904) ex parte et exclus. Section Zevherella; Wright in Dyer, Fl. Cap. 4: 436 (1906), pro parte; Pilger in Engler \& Prantl, Pflanzenf., Nachträge 1897-1907: 288 (1908); Hutch. \& Dalz., Fl. W. Trop. Afr. 2, 1:8 (1931); Eyma in Rec. Trav. Bot. Néerl. 33: 201 (1936), (with discussion on p. 157-158); Baehni in Candollea 7: 429 (1938); Phillips, Gen. S. Afr. Flow. Pl. ed. 2, 568 (1951) pro parte. 
Donella Pierre ex Baill., Hist. d. Pl. 11: 294 (1892).

Gambeya Pierre, Not. bot. Sapot. 6I (1891); Baillon. Hist. d. Pl. 1I: 296 (1892).

Type species: C. cainito L.. Sp. Pl. ed. 1, 192 (1753).

Trees or shrubs, rarely climbing; ultimate branches and lower surface of leaves often densely adpressed-tomentose; lateral nerves of leaves parallel. close or distant, usually spreading and curved near the margin: tertiary nerves usually inconspicuous. Stipules wanting or at least very early deciduous. Flowers axillary. or on the naked branches below the leaves. solitary or in fascicles. rarely sessile, usually isomerous. Sepals 5 (rarely 4. 6 or 7); lobes entire. imbricate. Corolla 5 (4-. 6- or 7-) lobed: lobes entire, imbricate: tube cylindric, urceolate or campanulate, usually short. Alterniperalous staminodes O. Stamens usually short, not or but little exerted: filaments inserted in the throat of the corolla tube at the base of the lobes and short. or inserted lower down and longer: anthers versatile. more or less dorsifix. ovate to triangular. often apiculate. sometimes somewhat sagittate at the base. Ovary hairy, 5- or more rarely 4-. or 6-7-loculated; style columnar, short. thick, glabrous: ovules with lateral or basilateral attachment. Berry 1-to few-seeded, but usually 3-5-seeded. Seeds with long and narrow ventral scar: testa hard. smooth and shiny; endosperm copious, cotyledons thin and foliaceous.

Between 100 and 200 species described. but undoubtedly some of them have been or have to be referred to other genera, because the absence of presence of alternipetalous staminodes is not a reliable character in Sapotaceae if not used in conjunction with other characters and many species without or apparently without staminodes but with seeds altogether different from the type species of Chrysophy/lum were at one time or another placed in the genus Chrysophyllum. Krause. Engler and later Eyma (cf. Eyma, op cit., p. 157-158) and Bachni (op. cit., p. 405-406) criticised the systems of classification of Sapotaceae in which the character of the alternipetalous staminodes is over-emphasized, so that, e.g., a separate tribe "Chrysophyllinées" based on the absence of staminodes was recognised by Dubard. Eyma (I.c.) and Lam [in Rec. Trav. Bot. Néerl. 36 (1939), p. 509-525] pointed out the relationships with the Sideroxyleae and indeed Chrysophy/hm is, in my opinion. to be included in this group. The genus Chrisophyllum - sensu lato - was split up (at least in Ms.) into a large number of smaller genera by Pierre (Pachistela, Donella, Gambeya. Zevherella, Malacantha, etc.). Some of these genera were adopted by Engler (1904. 1.c.) such as Pachystela and Malacantha. The remainder, at least as far as the African representatives are concerned. and if Engler's section Zeyherella is excluded. is a fairly homogenous group which is distinct from Sideroxylon s.l. and Pouteria s.l. in that the staminodes are completely lacking and the seed characters are different.

General Distribution: Mainly tropical America, less than 30 species in Africa, one in Madagascar: the few species recorded from tropical Asia. Australia and the Pacific have mostly been referred to other genera (e.g. Nesoluma).

The African representatives belong to two sharply defined subgenera:

(1) Chrysophylum L. subgenus Donella (Pierre ex Baill.) A. Meeuse. stat. nov. Donella Pierre ex Baill., Hist. d. Pl. 11: 294 (1891), pro gen. Chrysophyllum L. sect. Donella (Pierre ex Baill.) Engl., Mon. Sapot. Afr. 41 (1904).

Leaves with numerous close, parallel lateral veins, usually dark green above and as a rule quite glabrous; corolla with a short broad unceolate to subglobose tube.

Type species: Chrysophyllum roxburghii Don $=$ C. lanceolatum (BI.) DC. (India to New Guinea).

(2) Chrysophyllum L. subgenus Gambeya (Pierre) A. Meeuse, stat. nov. Gambela Pierre, Not. Bot. Sapot. 61 (1891) (pro gen.). Chrysophyllum L sect. Afrochrysophyllum Engl. in Engl \& Prantl.. Nat. Pflanzenfam.. Nachträge 272 (1897). Chrysophyllum sect. Gambeya (Pierre) Engl.. Mon. Sapot. Afr. (1904). 
Leaves with rather distant and usually on lower surface more or less prominent lateral veins and as a rule more or less rufo-tomentose on lower surface; corolla with a subcylindric to campanulate tube.

Type species: Chrysophyllum subnudum Baker (West Tropical Africa).

A few species of Chrysophyllum occur in Southern Africa. of which only two are treated here (one South African, the other occuring in Southern Rhodesia and Portuguese East Africa fairly clcse to the Union border):

Leaves almost completely glabrous and green when old, with fine parallel nervation, up to $11 \mathrm{~cm}$., but usually under $8 \mathrm{~cm}$. long....................... viridifolium.

Leaves rusty-tomentose or sometimes greyish tomentose beneath, often $10-20 \mathrm{~cm}$. long; lateral nerves distant, very prominent beneath............... 2. C. gorungosanum.

1. C. viridifolium Wood et Franks in Wood, Natal PI. 6: 569 (1912); Gerstner in J. S. Afr. Bot. 12: 48, Fig. 3 (1946) Type: Franks in herb. Wood No. 11636 from Stella Bush, Berea, near Durban, in NH, holo! photo in PRE!, in BOL and PRE, isos!).

A large tree, 10-30 m. high, with a girth at $2 \mathrm{~m}$. from the ground of $150 \mathrm{~cm}$. and over. Trunk usually unbranched for $5 \mathrm{~m}$. or more, and strongly many-ribbed to the origin of the branches. Bark grey. Innovations, petioles, pedicels, and calyx-lobes finely rusty velvety-tomentose, the older twigs and fruiting pedicel glabrous. Leaves scattered on the branches, thinly coriaceous, exstipulate, $4-8(-11) \mathrm{cm}$. long and $2-3 \cdot 5$ $(-4 \cdot 5) \mathrm{cm}$. wide (those of coppice shoots are the longest), oblong or (ob-) ovate-oblong. more rarely ovate or elliptic, obtuse or bluntly acuminate with oblong, obtuse about $8 \mathrm{~mm}$. long and about $3 \mathrm{~mm}$. wide acumen, more or less rounded but always decurrent at the base, dark glossy green above, lighter and dull beneath, glabrous when mature, except near the midrib and at the very base near the petiole beneath, with reflexed edge; midrib channelled above, prominent beneath and, at least when dry, discolourous, reddish or brownish; lateral nerves numerous (about 11 per $\mathrm{cm}$.), patent but not quite horizontal, often forked, almost straight, parallel (hence the leaf appearing striate), joining the fine intramarginal vein close to the margin. Petioles 5-10 (-12) $\mathrm{mm}$. long more or less dorso-laterally flattened, channelled above. Flowers $2-2.5 \mathrm{~mm}$. long, nearly globose, in clusters in the axils of the lower leaves and on raised warts on the older twigs; clusters few- to many-flowered (sometimes with over 20 flowers); bracts very minute or wanting; pedicels thin, almost capillary, 4-5 mm. long. Calyx-lobes free nearly to the base, erect, concave, ciliate. Corolla scarcely longer than the calyx; tube urceolate; lobes erect, ovate-oblong-rotundate, very obtuse or rounded, ciliate (at least at the lateral margins). Stamens inserted half way down the corolla-tube or zven lower; filaments terete, longer than the apiculate anthers. Ovary depressedglobose, 5-celled, densely rusty-villous, often somewhat lobed; style conical-cylindric from a broad base, thick, obtuse or truncate, longer than the ovary. Berry depressedglobose with a depression near the top (shaped like a small apple), often ribbed (at least when dried), 20-30 mm. long and 20-35 mm. in diam., smooth, glabrous, yellow when ripe with yellowish-white pulp saturated with white latex, 3-5-seeded; pedicel under fruit much incrassate, 5-8 $\mathrm{mm}$. long and 1.5-3 mm. thick, rugose; calyx usually not persistent in fruit. Seeds semi-circular-elliptic, compressed, 15-18 mm. long, 9-12 mm. wide and 5-6 mm. thick in centre, keeled and curved at the back, almost straight at the ventral side with a long narrow, linear scar occupying nearly the whole length of the seed; testa hard, shiny as if polished, bright yellowish-brown when dry.

NATAL.-Durban: Berea, Franks in herb. Wood No. 11636 (NH, holo.! PRE, BOL, isos!): Durban; Bayer 14485. Eshowe: Gerstner 2071 (NH), 2546 (NH, PRE, BOL), Lawn $202(\mathrm{NH}) ;$ Kotze $34=$ F.D. herb. No. 3178 (SAFD). Ingwavuma: Bayer s.n. (NH. No. 31432). Ngoya Forest: Mehliss FD No. 2686 (SAFD). 
Swaziland: N.N. in Forestry Herb. No. 5328 (PRE); Hlatikulu, Boocock $31=$ FD herb. No. 2686 (SAFD).

\section{Portuguese E. Africa.--Sul do Save: Gomes e Sousa 1648 (COI, PRE).}

C. viridifolium belongs to the subgenus Donella and is closely related to a number of African species of this section. From $C$. pruniforme Engl. (Mon. Sapot. Afr. p. 42. Fig. A) it differs in the shape of the fruit and the shorter seeds. C. welwitschii Engl. (op. cit.. 41. t. 13. Fig. A) is a climbing shrub (Angola, West Tropical Africa) and differs also in the shape of the fruit and the nervation of the leaves (in COI represented by: Welwitsch 4830, 4831, Gossweiler s.n. from Lunda. Saurimo and Gossweiler 1644, 4439, 4852, 5011, 6908, 8048).

C. bangweolense R. E. Fries in Schwed. Rhodesia-Kongo exp. 1: 254 (1914) (not seen) is, judging by the description, very closely related to $C$. viridifolium if not conspecific and occurs in Rhodesia. C. pentagonocarpum Engl. et Krause in Engl. Bot. Jahrb. 49: 387, Fig. 2 (1913) differs in the size of the fruits and seeds (E. Africa).

2. Chrysophyllum gorungosanum Engl., Mon. Sapot. Afr. 8: 44; (1904) Brenan in Mem. New York Bot. Gard. 8 (5): 498 (1954). Type: $R$. de Carvalho s.n. from Gorungosa in COI, lecto!, B. destroyed. C. fulvum S. Moore in J. Linn. Soc. Bot. 40: 13 (1911-1912); Type: Swynnerton 19 from Chirinda forest, Southern Rhodesia, in BM, not seen. duplicate in SRGH!

A large tree, up to at least $50 \mathrm{~m}$. high, with characteristic fluted bole. Buds and young branches rufo-tomentose, young leaves silvery-strigose above and silverytomentose beneath. Branchlets terete, glabrescent, densely leafy. Leaves on flowering branches $6-15 \mathrm{~cm}$. more rarely up to $20 \mathrm{~cm}$. long and $2 \cdot 5-3 \cdot 5$. rarely up to $6 \mathrm{~cm}$. wide, on a $7-16 \mathrm{~mm}$. long petiole; those on sterile branches larger, up to $30 \mathrm{~cm}$. long and 9 $\mathrm{cm}$. wide on a $12-28 \mathrm{~mm}$. long petiole; blade lanceolate-oblong to oblong-oblanceolate or (ob) lanceolate, cuspidate-acuminate (the acumen itself obtuse or subacute), narrowed and acute or sometimes cuneate at base, coriaceous, very soon glabrous and green above, densely rusty-tomentose beneath (or more greyish-tomentose when old); midrib impressed above, very prominent below; secondary nerves 12-17 on either side, impressed above, very prominent below, 5-7 mm., more rarely up to $14 \mathrm{~mm}$., apart. parallel, patent, ascending and becoming inconspicuous well within the margin: tertiary nerves hidden by the tomentum beneath but usually distinct above, \pm perpendicular to the main nerve and usually I parallel. connecting the secondary nerves at an angle between $60^{\circ}$ and $90^{\circ}$; ultimate nervation fine, areolate. Petioles terete. narrowly sulcate above, finely ferrugineo-pubescent or tomentose, 7-20 (-28) $\mathrm{mm}$. long. Stipules $O$. Flowers in the leaf axils or on the naked branches below the leaves in, sometimes very dense, clusters, or a few of them solitary. Bracts O. Pedicels 1-3 $\mathrm{mm}$. long, rather thick. shiny rusty-tomentose: some flowers almost sessile. Sepals almost completely free. broadly ovate, obtuse or very obtuse sometimes one of the outer ones subacute, very concave. more or less unequal, $\$ 3.5 \mathrm{~mm}$. long: the inner ones pale yellowish-brown strigose outside and thinner in texture than the coriaceous rustytomentose outer ones; all sepals densely pale fulvo-strigose inside, the inner ones ciliate on one side or all round. Corolla white, $\pm 4 \mathrm{~mm}$. long. the tube cylindric-inflated, slightly longer or about as long as the lobes and $=3 \mathrm{~mm}$. in diam., the lobes more or less erect and concave. obovate, ovate cr subrotundate, obtuse or very obtuse, sometimes with nearly straight truncate apical edge. about $1.5 \times 1.5 \mathrm{~mm}$.. densely ciliatebarbellate. Stamens inserted in the lower half of the corolla tube: filaments about $1.5 \mathrm{~mm}$. long; anthers subsagittate, shortly apiculate, about $1 \mathrm{~mm}$. long. Orary globose, densely hirsute. about $2 \mathrm{~mm}$. in diam.. slightly longer than the glabrous, cylindric, truncate style: ovules with baso-lateral attachment. Berry globose. sometimes somewhat apiculate, finely pubescent, up to about $3.5 \mathrm{~cm}$. in diam., $4-5$ seeded. Seeds 
19-21 mm. long. 11-12 mm. wide and 5-6 mm. thick in the middle, brown, ovateoblong, slightly attenuate and subacute at the base; the scar 12-14 mm. Iong and $1-2$ $\mathrm{mm}$. wide at the widest place.

Portuguese E. Africa.-Gorungosa: Rodrigues de Carralho s.n. (COI, lecto)!.

Southern Rhodesia.-Chipinga: Silinda, Chirida forest, Swynnerton 19 (SRGH: duplicate of type of C. fulvum S. Moore); Obermeyer 2161 (PRE, BOL); Hack 151/50, Whellan 163, McGregor 17/48, Wild 2096, 2245, Chase 620 (all in SRGH); Vári 1826, 1865 (PRE), Jack s.n. (SRGH. herb. No. 6355); Chase 427 and s.n. (SRGH, herb., No. 19262 and 19263); Fisher 1223 (PRE); photo of fluted bole of specimen by $N$. C. Chase in SRGH. "Eastern Border": Chorley' s.n. (SRGH No. 6686). Melsetter: Eyles 5721 (SRGH), Jack s.n. (SRGH No. 5962). Umtali: Eyles 5533 (SRGH).

Nyasaland.-Kota-kota Distr.: Nchisi Mountain, Brass 17067 (SRGH).

KenYa.-S. of Mt. Kenya; Hockliffe 1370 (PRE).

The type gathering of Chrysophyllum gorungosanum Engl. is sterile. As the material in Berlin was destroyed and Engler (l.c.) cited both "Herb. Coimbra" and "Herb Berlin ", the material in COI is taken as the lectotype. The type material consists of coppice shoots which are a perfect match of coppice shoots of specimens from the type locality of Chrysophy/lum fulvum S. Moore from Rhodesia (such as Obermeyer 2161). In addition, the only true Chrysophy/lum of the section Gambeya found in the area near the type locality is C. fulvum S. Moore (Gorungosa is the region bordering Chipinga and Melsetter in S. Rhodesia), so that there is very little doubt that these two names are synonyms.

Excluded species:

Chrysophyllum magalismontanum $\quad$ Sond. $=$ Pouteria magalismontana (Sond.) A. Meeuse, see p. 335.

Chrysophyllum natalense Sond. = Pouteria natalensis (Sond.) A. Meeuse, see p. 339. Chrysophyllum wilmsii Engl. = Pouteria magalismontana.

\section{EXPLANATION OF FIGURES.}

Fig. 1.-Sideroxylon inerme, seed and fruit (the seed seen from the side, the top and the base): (a) From a specimen Kotze 452 (from Amanzimtoti, Natal), (b) From a specimen Galpin 2468 (from Stutterheim, E. Cape). (All figures if not otherwise stated, natural size).

Fig. 2.-Chrysophyllum viridifolium, seed and fruit (from Gerstner 2546 Eshowe, Zululand). In this figure, and in all subsequent figures of seeds, the seed is shown from the lateral side and from the ventral side.

FIG. 3.-Chrysophyllum gorungosanum, seed and fruit (from Obermeyer 2161, Chipinga, S. Rh., in PRE).

FIG. 4.-Pouteria magalismontana, seed and fruit (from Gerstner 5728, Louis Trichardt, N. Transvaal). (In the lateral view a part of the testa has been removed).

FIG. 6.-Pouteria natalensis, seed and fruit (from Lawn 57, Eshowe, Zululand). 

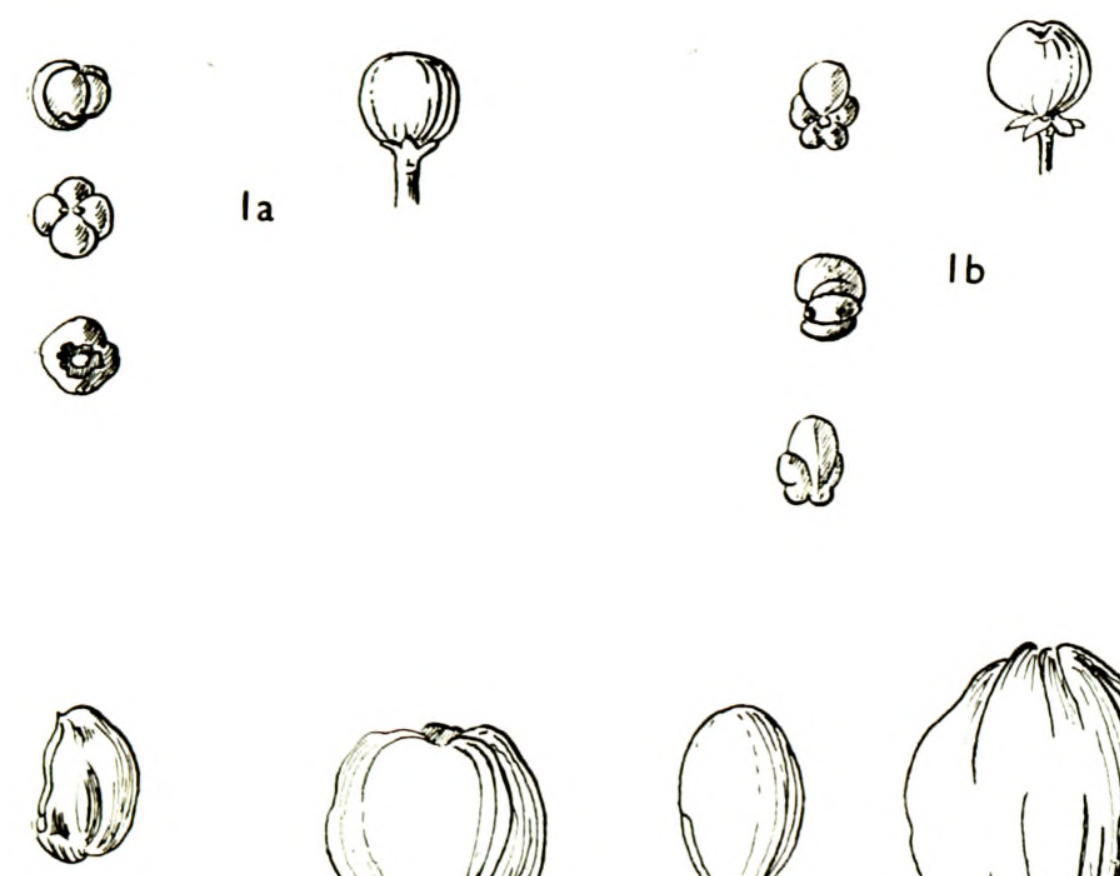

(1)
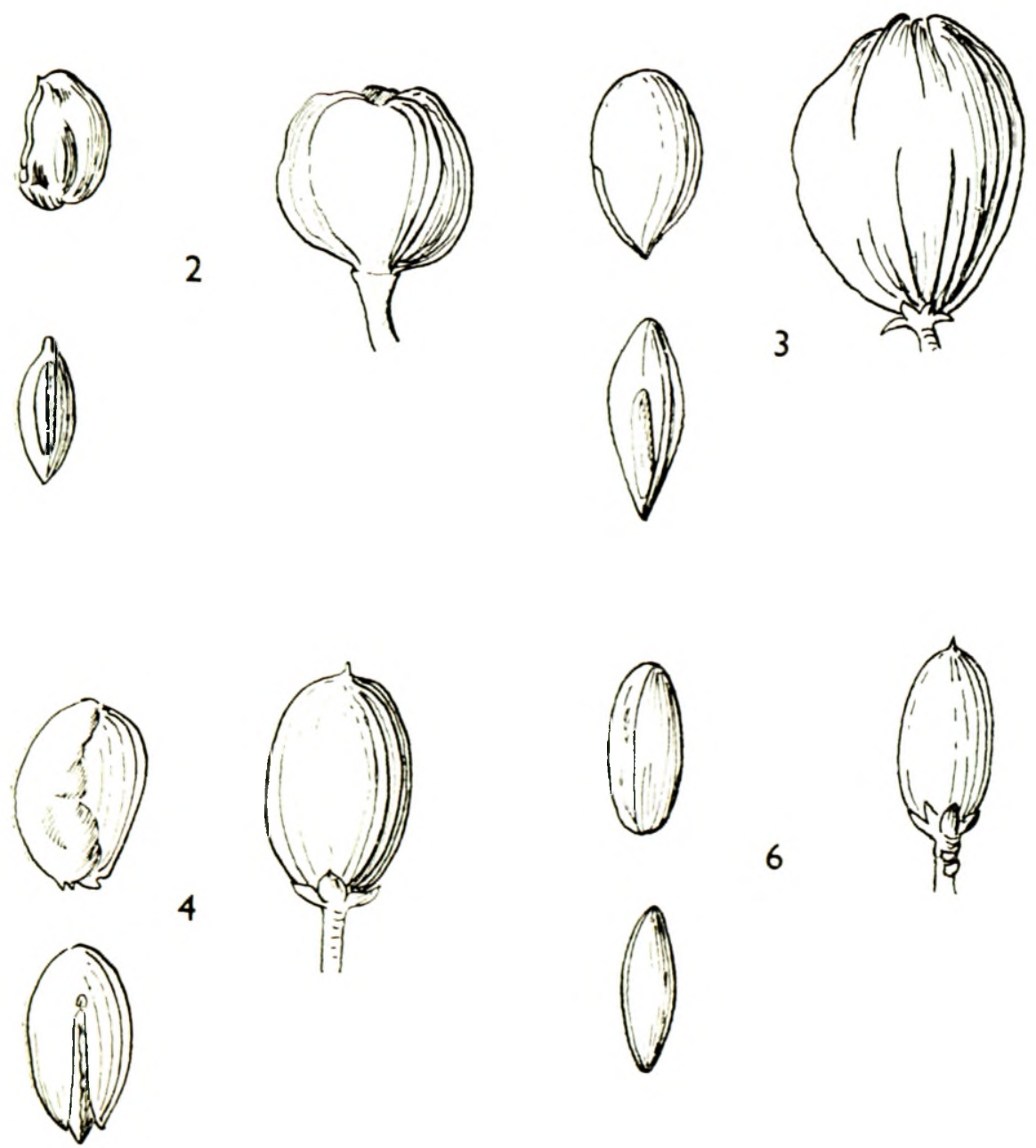


\section{POUTERIA}

Aubl., Hist. PI. Guiane Fr. 1: 85 (1775); Eyma in Rec. Trav. Bot. Néerl. 33: 159 (1936); Baehni in Candollea 9: 149, pro parte; Herrmann-Erlee \& Royen in Blumea 8: 453 (1957).

Lucuma Molina, Saggia Chil. 186 (1782).

Sersalisia R. Br. Prodr. 529 (1810), p.p., as to type species.

Zeyherella Pierre ex Baill., Hist. d. Pl. 11: nota 3 (1892), nomen nudum.

Pachystela Pierre ex Engl., Mon. Sapot. Afr. 35 (1904).

Chrysophyllum L. sect. Zeyherella (Pierre ex) Engl. op. cit., 47.

Breviea Aubr. et Pellegr. in Bull. Soc. Bot. France 81: 792 (1934).

Aningeria Aubr. et Pellegr., op. cit., 795.

Chrysophyllum Auct. et Sideroxylon Auct., ex parte.

Type species: $P$. guyanensis Aubl. (South America).

Trees or shrubs. Branches terete, the young ones often tomentose. Leaves varying from papyraceous to coriaceous, exstipulate or occasionally stipulate, often crowded towards the tips of the branches; often hairy on both sides or the lower side, usually more or less glabrescent but rarely ultimately or initially quite glabrous; secondary nerves as a rule distinctly stronger than tertiary ones; tertiary nervation mutually parallel or reticulate, parallel with or more or less perpendicular to secondary nerves; petioles usually distinct; stipules, if present, subulate or setaceous. Flowers fasciculate in axils of leaves or leaf-scars, sometimes inserted on brachyblasts (raised warts, etc.), rarely solitary, pedicelled or sometimes sessile; 2-4 bracteoles sometimes present. Sepals generally 5, occasionally 4 or 6 in a single whorl, connate at the base only, subequal or more or less unequal (innermost narrower), deciduous or persistent in fruit. Corolla exserted, sometimes only a little so, tubular to campanulate; lobes 5 (occasionally 4 or 6-8), more or less erect to somewhat spreading but never reflexed; the tube short but distinct to occassionally rather long. Alternipetalous staminodes generally 5 , but sometimes fewer, or absent, occassionally 6-8, generally lanceolate or subulate, but sometimes squamiform or larger and petaloid. Stamens 5 (occasionally 4 or 6-8), inserted in or near the throat of the corolla. Ovary generally 5-loculated, sometimes with a subcupular disc, more or less conical, gradually contracted into the, usually short, cylindric or subulate style. Fruits 1-5-seeded but often only 1 or 2 seeds develop in many species; pericarp various but rarely hard. Seeds with a thin or sometimes rather thick, often brittle, crustaceous testa and a large to very large cicatrix covering the ventral half of the seed or more, sometimes cicatrix smaller, linear or oblong; cotyledons thick and fleshy; endosperm absent or present as a thin membranous layer.

The delimitation of this genus, as given here, agrees with the circumscription of Herrmann-Erlee and Van Royen (l.c.), except in one character: I include some species with more or less persistent stipules, whereas the Leiden authors state: "Leaves . . . exstipulate". As the leaves of Sapotaceae are in principle all stipulate, but apparently often exstipulate because the stipules are so early deciduous, 1 cannot accept the presence or absence of stipules in this family as a very important generic character.

This delimitation agrees also very well with Eyma`s conception of the genus based on a study of South American species. As circumscribed here there are about 150 species, in tropical and subtropical America, Africa, Asia, Australasia and the South-West Pacific region.

The genus, as defined here, is considerably smaller than Baehni's enormous genus Pouteria of 300-500 species, which includes forms with and without endosperm and with an enormous variation in the characters of the corolla, the stamens, etc. Mr. J. P. H. Brenan of Kew criticized Baehni's very broad generic limits of Pouteria in 
Mem. New York Bot. Gardens 8 (5): 499 (1954) as follows: “In rejecting Baehni”s wholesale amalgamation of African sapotaceous genera under Pouteria Aubl.. I recognise that the delimitation of genera in this family is often fiendishly difficult and very much a matter of opinion. But at the same time I remain unconvinced that the proposed fusion is going to clear the air and make identification easier ". This statement expresses aptly the opinion of other modern authors. Van Royen has especially critisized the "amalgamation" of species without endosperm (which he retains in Pouteria if not referred to different genera for other reasons) and those with copious endosperm (referred to Xantholis Rafin. and Planchonella Pierre), see Blumea 8: 238-239. Dr. Van Royen kindly pointed out to me that at least some of the African species included by Baehni in his large genus Pouteria are indeed Pouteria sensu Van Royen. but apparently Planchonella does not occur in Africa. My studies. limited as they are, confirm this conclusion. ( $\left.{ }^{1}\right)$

As far as the African sapotaceous genera are concerned, the species to be included in Pouteria sensu mihi are sharply distinghuished from the genus Chrysophy/lum sensu mihi in that they have usually alternipetalous staminodes and seeds with a thin testa. a broad ventral scar and no endosperm. whereas the other genus lacks alternipetalous staminodes and has seeds with a hard thick testa. a narrow ventral scar and copious endosperm. This implies that several species at one time under Chrysophyllum have to be transferred to Pouteria.

On the other hand, there are some African genera included in Pouteria by Baehni which, although they have the same type of fruit and seed. (i.e. thin testa. large scar. no endosperm) to my mind, do not belong here because they differ in other respects. $V$ incentella Pierre with its totally reflected corolla-lobes. very short corolla-tube. long and capillary stamens, is clearly distinct and is retained. Mr. Brenan independently came to the same conclusion. The genus Synsepalum A. DC. of tropical West Africa may also have to be retained on account of the strongly gamosepalous calyx.

It is difficult to say how many species of Pouteria sensu mihi there are in Africa. because I have studied only a few representatives and there are probably more. A count of Baehni's species (African) under Pouteria. omitting those belonging to Vincentella and Synsepalum. and including some which Baehni refers to Chrysophyllum but are better placed in Pouteria, shows a total of about 20 African species probably to be retained in Pouteria.

Leaves with secondary veins $1-3 \mathrm{~cm}$. apart and very prominent on lower surface... 1. P. hresipes.

Laaves with secondary veins much closer (several per $\mathrm{cm}$.) and not very prominent:

Leaves usually rounded or emarginate at the apex. usually rusty-tomentose rarely more silvery, on lower surface; flowers fasciculate or solitary. often on raised warts on the naked branches below the leaves: pedicels and calyx rusty-pubescent

2. P. magalismontana.

Leaves usually bluntly acuminate at the apex, usually silvery-white on lower surface; flowers solitary or 2-3 together sessile in the leaf-axils. caly $x$ with a dark tobaccobrown pubescence.................................. 3. P. natalensis.

1. P. brevipes (Baker) Baehni in Candollea 9: 290 (1942); (for full synonymy see Baehni). Sideroxylon brevipes Baker in Oliv.. Fl. Trop. Afr. 3: 502 (1877), type: Kirk s.n. in $\mathrm{K}$, from Zanguebar.

(1) Note added in proof: Aubréville and Pellegrin in Bull. Soc. Bot. France 105: 37 (1958; raised Engler's section Zevherella to generic rank (including only Chrysophyllum magalismontamum Sond.) and described a genus Boivinella with 5 species including Chrysophyllum argyrophyllum Hiern, C. wilmsii Engl, and $C$. natalense Sond. The first two I consider to be taxonomical synonyms of $C$. magalismontamum (= Pouteria magalismontana, see p. 335), which these authors place in a different genus (Zeyherella)! This is an example of the other extreme, viz., excessive splitting of genera. resulting in the creation of a number of (to my mind, unnecessary) synonyms and adding to the confusion instead of clearing up the generic delimitations in the African Sapotaceae. 
Pachystela brevipes (Baker) Baill. in Bull. Soc Linn. Paris 11: 947 (1891), nomen nudum. P. hrevipes (Baker) Engl., Mon. Sapot. Afr. 37 (1904). P. cinerea (Engl.) Pierre ex Engl., op cit., 36, t. 12, incl. vars.; type: Weluitsch 4824 in B十, isotype $\mathrm{BM}$, type number $\mathrm{COI!}$

Bakeriella hrevipes (Baker) Dubard and B. cinerea (Engl.) Dub. in Ann. Mus. Col. Marseille 20: 27 (1912).

A tree reaching a height of at least $10-15 \mathrm{~m}$. Branches rather thick, at first thinly pubescent or thinly brownish-tomentose, glabrescent, later longitudinally fissured and often turning ashy-gray or almost white. Stipules coriaceous, linear-subulate, 5-15 mm. long, brown rusty-pubescent or glabrous, very acute. Petioles stoutish, 5-10 (-15) mm. long, 2-4 mm. thick, flat above, when dry longitudinally sulcate. Leaves lanceolateoblong or oblong-oblanceolate to obovate-oblong, $5-20 \mathrm{~cm}$. long and $2-8 \mathrm{~cm}$. wide, coriaceous, shiny and glabrous above, much paler and dull, shortly whitish-tomentose or glabrous below, with obtuse or shortly and bluntly acuminate apex and narrow, cuneate or decurrent-attenuate base, and revolute edge; midrib impressed and distinctly keeled above, prominent and when dry longitudinally fissured below; lateral veins $8-10$ on either side, distant $(1-3 \mathrm{~cm}$. apart $)$, arcuate-ascending, impressed above, very prominent below, all reaching the edge of the leaf or nearly so; ultimate nervation coarsely reticulate mainly more or less perpendicular to the midrib; veinlets very delicate and inconspicuous. Pedicels short and thick, $\pm 3 \mathrm{~mm}$. long and $1-2 \mathrm{~mm}$. in diam., covered with a pale fawn tomentum. Flovers clustered in the axils of the lowermost leaves or on the naked wood below the leaves on raised warts, sweet-scented. Sepals ovate-oblong, oblong or oblong-lanceolate (the inner ones narrower), 3.5-4.5 $\mathrm{mm}$. long and $1 \cdot 5-3 \mathrm{~mm}$. wide, subacute or obtuse, more or less concave, pale fawnytomentose outside and inside. Corolla glabrous; the tube $2 \mathrm{~mm}$. long and $1-1.5 \mathrm{~mm}$. in diam.; the lobes oblong or ovate-oblong, subacute or obtuse $\pm 4 \mathrm{~mm}$. long and $1 \cdot 5-2 \cdot 25 \mathrm{~mm}$. wide. Alternipetalous staminodes glabrous, lanceolate-linear, linearsubulate, or filiform, acute, acuminate and often lacerate or incised-dentate (the filiform ones not infrequently with a terminal thickening or even a small sterile anther), usually shorter than the filaments, but occasionally equalling the stamens, sometimes small, squamiform or O. Filaments linear-filiform, 3-4 mm. long; anthers pink (Mrs. Faulkner), 2-2.5 mm. long. Ovary ovoid, $2 \mathrm{~mm}$. long and $1.5 \mathrm{~mm}$. in diam., distinctly $5-$ lobed-sulcate below, densely fulvo-villous, situated on a flat disc; style thick, columnar, angular, widened, subcapitate-truncate and indistinctly 5-lobed at the apex, 4-5 $\mathrm{mm}$. long, covered with long hairs at the base or sometimes half way up. Fruiting pedicels hardly changing but more or less glabrescent; the calyx persistent, spreading but not reflexed. Fruit edible, yellow when ripe, ellipsoid, 15-22 $\mathrm{mm}$. long and 9-12 $\mathrm{mm}$. in diam. Seed the same shape as the fruit but smaller, 12-16 mm. long and 6-9 $\mathrm{mm}$. in diam., scar occupying more than half the surface of the seed; testa smooth and shiny light brown, the scar duller and paler, somewhat rough.
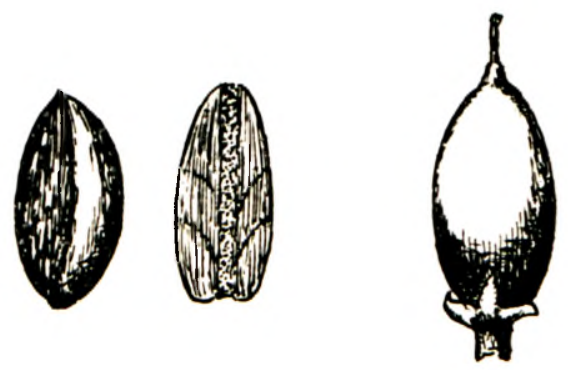

FIG. 5.-Pouteria brevipes, seed and fruit (from Zenker 4324, Cameroons, in PRE). 
Widespread in tropical Africa. but not recorded from Northern Rhodesia. I have seen numerous specimens from tropical East and West Africa in several herbaria and only cite those occuring in Southern Africa:

Portuguese East Africa.-Manica e Sofala: Chipinga, Busi Drift (East of Melsetter, S. Rhodesia), Whellan 133 (SRGH). Maribane. Gomes Pedro 4193 (LMJ, PRE); "Na floresta de Maronga ". Simão 375 (LM); Matarara do Lucite. Gomes Pedro 4278 (LMJ. PRE). Zambezia: Quelimane Distr. Metola. Barbosa \& Carvalho 4002 (LM. PRE). between Mualama and Gilé. Bartosa \& Carralho 4342 (PRE): Mocuba, Faulkner "Kew 18 "(PRE. SRGH. COI). Niassa: Nampula. Nova Chaves. Barbosa \& Lemos 1780 (LM): Pto. Amelia. Mueda. Barbosa 2238A (LM. PRE); between Mueda and Chomba Barbosa 2248 (LM).

Southern Rhodesla. - Vumba: Wychwood, Ball 14 (SRGH. PRE). Melsetter: between Hayfield and Lusitu river/Haroni, Drummond 5001 (SRGH. PRE).

Angola.-Cuanza: Golungo Alto, between Cambondo and Luinha River. W $\mathrm{el}$ witsch 4818 (COI): Pungo Andongo: Welwitsch 4824 (COI; type number of Pachystela (inerea); Calemba Island in Cuanza Riv.. Welwitsch 4826 (COI); Ponta Filomene de Camera, nr. Cuanza Riv., Gossweiler 10649 (COI).

As regards the author of the combination "Pachlstela hrevipes". the genus Pachystela was only validly described in 1904, so that Baillon's name "Pachystela hrevipes (Baker) Baillon". published in 1891, is a nomen nudum and "Pachistela brevipes (Baker) Engl." is the correct citation under the Rules.

2. P. magalismontana (Sond.) A. Meeuse, comb. nov.

Chrysophyllum magalismontanum Sond. in Linnaea 23: 72 (1850) (sphalm. " magalismontana"); Engl.. Mon. Sapot. Afr. 47 t. 16, f. C (1904): Wright in Dyer. Fl. Cap. 4. 1: 437 (1906); Phillips in Flow. Pl. S. Afr. 3. t. 98 (1923); Marloth. Fl. S. Afr. 3: 36. t. 10 (1932): Gerstner in J. S. Afr. Bot. 12: 40, Fig. 4 (1946), and 14: 171. Figs. A-F (1948): Brenan in Mem. New York Bot. Card. 8 (5): 498 (1954); type: Zerher 1849 from Magaliesberg. Transvaal in herb. Sonder nunc S, holo, BOL and SAM. isos!). C. argyrophyllum Hiern. Catal. Afr. Pl. Welw. 3: 641 (1898): Engl. op. cit., 46, t. 16. Fig. A: Brenan \& Greenway. T.T. Check List 2: (1949); type: Welwitsch 4827, 4828, 4829, syns. in BM. 4828 in COI!) C. antunesii Engl. in Engl. Bot. Jb. 32: 137 (1903); type: Antunes 98 (B †. COI. lecto.!). C. carvalhoi Eng., op. cit. (1904), 47; type: Rodrigues de Carralho s.n. in COI. lecto!, B †. C. wilmsii Engl.. op. cit. (1904), 46. t. 16, Fig. B: Wright. op. cit.. 437: type: Wilms 1812 in B †. holo. K, iso. C. gossweileri De Wild., Pl. Bequart. 4: 130 (1926); type: Gossweiler 2808 in BR. dupl. in COI!

Sideroxylon randii Sp. Moore in J. Bot. 41: 402 (1903): Wright, op. cit. 439; type: Rand 1017 from Johannesburg. BM, holo.: photo in $\mathrm{J}$ !.

Pachystela magalismontana (Sond.) H. Lec. in Bull. Mus. Hist. Nat. Paris 25: 192 (1919). P. argyrophylla (Hiern) H. Lec., l.c.

A large tree when growing in forests (up to at least $15 \mathrm{~m}$. high), but in its more characteristic form, growing on stony koppies and rocky ledges in the Transvaal, a shrub. already flowering and fruiting freely when only about $1 \mathrm{~m}$. high. Leaf-hearing branches, especially in the shrubby form, often stout, 5-10 mm. thick. with short internodes. Innovations and twigs rufo-tomentose. Leaves often near apex of otherwise leafless branches, stipulate and sometimes thinly papyraceous when young, coriaceous when mature, first with a white bloom but soon glabrous and green above, rufo- or aureotomentose (older ones often more greyish- or silvery-tomentose, sometimes with a pale pink or mauve tinge) below, $4-15 \mathrm{~cm}$., sometimes up to $30 \mathrm{~cm}$. long. $2-5 \mathrm{~cm}$., sometimes up to $7 \mathrm{~cm}$., wide, those of the characteristic shrubby form usually deffexed, rather small (up to $12 \mathrm{~cm}$. long and $5 \mathrm{~cm}$. wide), oblong-obovate, obovate-elliptic or oblong, usually 
rounded or slightly narrowed at the base. rarely obovate with cuneate base; emarginate, retuse or at least obtuse at the apex. sometimes mucronate with short, often blackish, mucro, sometimes more strongly tapering at the base and oblanceolate-oblong; petiole 6-12 $\mathrm{mm}$. long; those of the forest form usually distinctly cuneate at the base, lanceolate, oblong or oblanceolate-oblong to oblanceolate-cuneate, occasionally (on coppice shoots) up to nearly $30 \mathrm{~cm}$. long and $7 \mathrm{~cm}$. wide on a longer (up to $24 \mathrm{~mm}$. long) petiole, but usually smaller, with obtuse, rounded, emarginate or retuse, sometimes shortly and bluntly acuminate, occasionally mucronate apex; midrib immersed and narrow canaliculate above, very prominent below; secondary nerves numerous $(6-7$ per $\mathrm{cm}$.). slender, usually inconspicuous above, partly hidden under the tomentum, but on the older leaves often loosing their pubescence and becoming slightly prominent beneath, patent, straight, but distinctly ascending and curved towards the margin. sometimes joining and forming an irregularly sinuous, often very inconspicuous intramarginal vein, more rarely bifurcate and archingly joining; tertiary nerves parallel to and thinner than secondary ones, somewhat sinuous, mostly not reaching the margin without branching or joining other veins, often inconspicuous; ultimate reticulate nervation usually sparse, inconspicuous, mainly present towards the margin and $t$ parallel to secondary and tertiary nerves. Petioles thick, subterete but often longitudinally ribbed or angled, at least when dry, rusty- or aureo-pubescent, later sometimes ashy-greypubescent on a brown background. Stipules long-subulate, often curved, pubescent, soon deciduous. Flowers in few- to many-flowered, sometimes very dense, fascicles, the majority usually on the lower leaflets parts of the branches or on older wood on sometimes rather large, raised warts, and fewer, or none, in the leaf axils. Bracts $\mathrm{O}$ or very minute. Pedicels densely rufo-tomentose, varying in length from $t 2 \mathrm{~mm}$. to

$5 \mathrm{~mm}$., more rarely up to $=10 \mathrm{~mm}$. long. rather stout and gradually or more abruptly widening at the top into the calyx; rarely flowers sessile. Caly:x 2.5-4 (-5) mm. long, rufo-tomentose outside; sepals free nearly to the base, often unequal, ovate, obtuse or subacute, often greyish-pubescent inside, $2-4.5 \mathrm{~mm}$. long and $2-3.5 \mathrm{~mm}$. wide. Corolla white or whitish, turning brown (according to the labels also "pink" or " red" in Rhodesia and East Africa, but this may refer to already wilted flowers), glabrous, varying in length from scarcely longer than to about $2 \mathrm{~mm}$. longer than the calyx; tube cylindric-urceolate, usually $1-1.5 \mathrm{~mm}$. sometimes up to $2 \mathrm{~mm}$., rarely only about $0.5 \mathrm{~mm}$. long; the lobes somewhat to distinctly spreading, broadly ovate, obtuse or subacute, $2-4.5 \mathrm{~mm}$. long and about $2 \mathrm{~mm}$. wide. Alternipetalous staminodes $\mathrm{O}$ or sometimes $1-5$. inserted just below the sinuses between the corolla-lobes. much smaller than the latter, scale-like and minute or sometimes petaloid, ovate or suborbicular. more or less irregularly serrate. dentate or incised in the supper half, up to $1.5 \mathrm{~mm}$. long and $0 \cdot 5-1 \mathrm{~mm}$. wide. Stamens subincluded, inserted at the base of the corolla-, lobes; filaments 1.5-2 mm. long; anthers 1-2 mm. long. somewhat cordate-sagittate at the base before dehiscence, acute, apiculate; sometimes stamens sterile, staminodial, either resembling a stamen with a filament-like basal portion and a sagittate-cordate, broader top which often shows two longitudinal marks (cf. Gerstner, 1948. Figs. A-F), or more irregularly shaped, very rarely (fide Engler, op. cit., 47, t. 16, Fig C, and c) lanceolate, petaloid. Ovary globose-ovoid, about $2 \mathrm{~mm}$. in diam., densely villous. 5-, sometimes 3- or 4-celled, gradually passing into the $1.5 \mathrm{~mm}$. long, glabrous style. Fruit ellipsoid, $25 \mathrm{~mm}$. long $18 \mathrm{~mm}$. wide. dark red when ripe, edible, crowned with the persistent style, 1- or sometimes 2-seeded. Seeds of 1-seeded fruits compressed -ovoid, 16-20 mm. long, 14-16 mm. broad and 8-11 mm. thick; those of 2 -seeded fruits with one flattened lateral side; testa light brown, shiny, thin and brittle when dry; scar linear-triangular, ventral, occupying about $\frac{3}{4}$ of the length of the seed; $2 \mathrm{~mm}$. wide or more in widest place.

General Distribution.-Tropical Africa, from the Congo to Tanganyika and southwards to Angola, Bechuanaland, the Transvaal, Swaziland and Natal. At least in the Transvaal this species is apparently confined to quartzite and granite rocks, so that the 
plant is as much an indication of the formations as the formations are an indication of the occurence of $P$. magalismontana. In N. Zululand. for instance, where quartzite rocks occur locally, $P$. magalismontana is only found in the area where the rocks come to the surface.

Selected citations;

Bechuanaland. - Kanye: Hillary \& Rohertson 613; Lobatsi Govt. Farm: Miller $\mathrm{B} / 246$.

TransvaAL. - Zoutpansberg: Louis Trichardt, Hanglip. Gerstner 5728. Sebasa: near Sebasa, Codd \& Dyer 4515. Pietersburg: Woodbush, Hoffmamn 22. Warmbaths: Warmbaths. Leendertz s.n., Burtt Davy 2616. Hutchinson 1883. Brits: Silkaatsnek, Smuts \& Gillett 1061. Magaliesberg Range: Zeyher 1849 (BOL. SAM. type gathering); Burke 377 ("twin type ". BOL). Pretoria: Pretoria. Leendertz 322, 510; Burtt Davy" 2675, Pole Evans 30, 161; Hutchinson 2314. Nelspruit: Kruger National Park, v. d. Schijff 59, Codd 5745. Barberton: Burtt Davy, 258. Marico: Zeerust. Gersther 4413 (NH). Rustenburg: Leendertz s.n.. Pegler 1033. Witwatersrand: Johannesburg. Rand 1017 (PRE, fragment of type of Sideroxylon randii); Gerstner 6418. 6424; English in Herb. Galpin 1486. Heidelberg: Leendertz s.n. (TRV. No. 8077): Delmas: Naude s.n. Brits: Silkatsnek, Smuts \& Gillett 1061; Hartebeespoort, Prosser 1297 (NBG). Magaliesberg Range: Zeyher 1849 (BOL, SAM, type gathering); Burke 377 (BOL). Pretoria: Pretoria, Leendertz 322, 510; Burt Davy 2675; Pole Elans 30, 161; Hutchinson 2314.

SwaZiland.-Codd 1585: Acocks 12850; Miller S/108; Bolus H. No. 12110 (BOL).

Natal and Zululand.-Ngotshe: Magut, Pongola, Gerstner 2461: Ngome Forest Stat.. Tustin = FD herb. No. 6552.

Portuguese E. Africa.-Manica e Sofala: "Floresta do Garuso", Simão 552 (PRE: with lanceolate, petaloid epipetalous staminodes instead of stamens); Chimanimani Mts.. Plowes 1250 (SRGH); Gorungosa, Rodrigues de Carvalho s.n. (COI, sterile branch, type of Chrisophyllum carvalhoi Engl.).

There has been some misunderstanding as regards the occurrence of the reduced sterile flowers and their proper significance. Sonder described Chrysophyllum magalismontanum as having normal stamens, citing Zeyher 1849 as the type number. Engler (1904) described $C$. magalismonatum as having female flowers with lanceolate epipetalous staminodes and oblong leaves (he cites Zey/her 1849 and Burke) and distinguished C. wilmsii, which is described as having leaves that are much narrowed at the base, and fertile anthers. Wright (in FI. Cap. 4, 1: 437) distinguished these two as follows:

Leaves oblong, obtuse, cbtuse at the base: flowers pedicellate........... magalismont antm Leaves oblong, obtuse, mucronulate, acute at the base, flowers shortly pedicellate....... II ilmsii

Wright made no mention of staminodes, but also cited Zeyher 1849 and Burke 377 under C. magalismonatum.

Gerstner identified the form with sterile anthers with $C$. wilmsii Engl., which is not correct, but he discovered that $C$. magalismonatum under unfavourable conditions produces depauperate flowers (Gerstner, op. cit. 1948, p. 171), especially after a severe drought of several months. As soon as sufficient rain has fallen the same plants develop complete flowers. The sterile stamens are sometimes transformed into lanceolate epipetalous staminodes (e.g., in Sinião 552 and in a specimen leg. N. N. from Bulawayo= SRGH No. 5579), and the specimen Zeyher 1849 in the Berlin Herbarium studied by Engler is probably a branch with such abnormal flowers, whereas other specimens of the gathering Zeyher 1849 such as those in BOL! and SAM! (taken from other branches or other trees ?) bear normal flowers and this explains the apparent controversy. I have also found that fertile and sterile stamens can occur in one flower. and 
these sterile anthers, sometimes appearing as subpetaloid epipetalous staminodes are clearly abnormal, at any rate they have no taxonomic value. The difference in leaf shape as indicated in Fl. Cap. breaks down altogether as a character and $C$. magalismontanum and $C$. wilmsii are clearly synonomous.

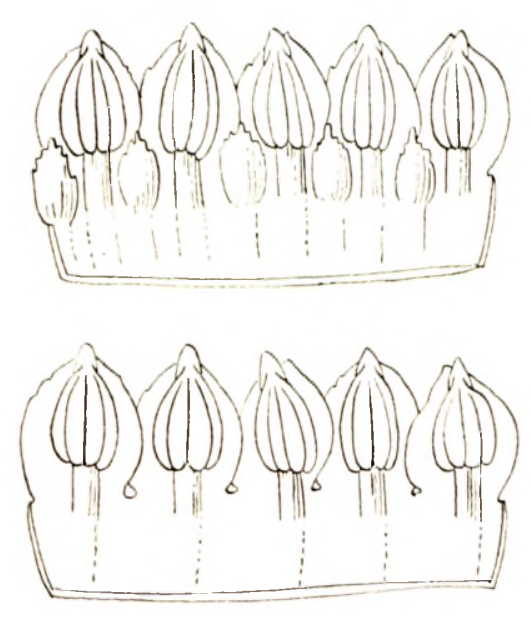

Fig. 7.-Pouteria magalismontana, opened corolla-tubes of two flowers of Gerstner 6418 (from Johannesburg. Transvaal), x 5. seen from the inside. Above: flower with 5 developed alternipetalous staminodes, below: flower without staminodes.

The presence or absence of alternipetalous staminodes is independent of the degree of development of the stamens and they also occur in flowers of Gerstner's forma depauperata (such as those of the specimen Gerstner 6424 cited by him). These alternipetalous staminodes are by no means rare: if sufficient flowers of a single specimen are dissected, some flowers with 1-5 staminodes (at least one in 10) are found. However, some specimens (or perhaps some individual plants) show a much higher frequency of flowers with developed staminodes of this type, such as Gerstner 6418 in which the majority (over $60 \%$ ) of the flowers possess petaloid staminodes (see Fig. 7). Moore's type specimen of Sideroxylon randii (Rand 1017 in BM) is obviously such a special case. In every other respect, the description of $S$. randii and a photo of the type specimen (in J) agree perfectly with $C$. magalismontanum. Mr. de Winter, who examined the type specimen, confirmed my opinion and sent one flower of Rand 1017 which proved to be identical with $P$. magalismontana, so that $S$. randii falls into synonymy. This is a good example of the unreliability of the absence or presence of alternipetalous staminodes as a main distinguishing character in this family. Moore, after observing distinct staminodes, made it a Sideroxylon, whereas Sonder and Engler, who did not see distinct staminodes, referred the same species, apparently without any doubt, to Chrysophyllum.

As regards the identity of $P$. magalismontana and Chrysophyllum argyrophyllum Hiern, the differences indicated by Engler in his monograph are very slight. The differences reported are: (1) colour of the lower leaf surface (rusty-tomentose in magalismontanum, grey or silvery in argyrophyllum); (2) leaf shape (oblong to obovate-oblong in the first, oblanceolate (ioblong) in the second); (3) petioles, pedicels and calyx rustytomentose in the first, greyish-pilose in the second. These differences are not important, because the pubescence may be rusty- or greyish-tomentose on various parts of the same specimen, older parts tending to change from rusty-brown into grey and the leafshape varies even in one of the original gatherings cited by Hiern: Welwitsch 4828 
(in COI!). I have seen many specimens from Angola. Rhodesia and East Africa and there is no sharp distinction between those referred to $C$. argyrophyllum in various herbaria and those referred to $C$. magalismontanum.

The species under discussion was redescribed several times again: Chrisophyllum antunesii Engl. and C. gossieileri De Wild. are small-leaved forms from Angola (I have seen types or isotypes of these in COI); $C$. carvalhoi Engl. is a form with narrow, lanceolate and acuminate leaves, collected in Moçambique (type in COI!).

\section{P. natalensis (Sond.) A. Meeuse, comb. nov.}

Chrysophyllum natalense Sond. in Linnaea 23: 72 (1850); Engl.. Mon. Sapot. Afr. 43, t. 34, Fig. C (1904); Wood, Natal Pl. 4, t. 378 (1906): Wright in Dyer, Fl. Cap. 4, 1: 437 (1906); Sim, For. Fl. Cape Col. 252, t. 94. (1909); Gerstner in J. S. Afr. Bot. 12: 48, Fig. 2 (1946); type: Gueinzius 181 from Berea near Durban in herb. Sonder nunc $\mathrm{S}$.

A medium-sized tree, $8-15 \mathrm{~m}$. high, but often fruiting freely without much height, "growing mostly in the open or gregariously" (Sim). Stem up to $50 \mathrm{~cm}$. in diam.. with smooth bark, according to Sim and Gerstner yielding a valuable timber. Twigs slender, terete. grey, glabrescent; internodes decreasing in length towards the apex, so that the leaves are crowded at the tops of the twigs. Innovations and calyx densely dark tobacco-brown-tomentose. Leaves 6-12 (-15) cm. long and 2-4 (-5) cm. wide. obovate-lanceolate (ob) lanceolate-elliptic or (ob) lanceolate-oblong. shortly acuminate, acute or obtuse, at the very apex canaliculate-subdeflexed, sub-emarzinate and mucronulate (occasionally in a few leaves retuse or emarginate), gradually tapering into the acute or somewhat acuminate base. when mature green (drying a characteristic greyishgreen), glabrous and very shiny above, very minutely greyish- or silvery-tomentose. later sometimes glabrescent, beneath, with entire, subdeflexed and undulate margins: midrib immersed and channelled above, prominent and conspicuous below; secondary nerves thin, raised, about 20 on either side, patent, almost straight, bifurcate usually well within the margin and archingly joining. no distinct intramarginal vein present; teritiary nerves inconspicuous, mostly parallel to secondary ones. Petioles $6-12(-14)$ $\mathrm{mm}$. long, canaliculate above, often brown or blackish, rugose. with two short dorsal ridges where the slightly decurrent leaf-base ends and there seemingly distinctly narrowing into the leaf-base when seen from above (at least when dry), but in fact continuous with the midrib. Stipules wanting or at least very early deciduous. Flowers sessile, in clusters of $1-3$ (sometimes more) together in the leaf axils; bracts small. inconspicuous, broadly triangular, rusty-pubescent, or wanting. Calyx $4 \mathrm{~mm}$. long. divided more than half way down, the segments erect. ovate, subacute. Corolla "white" or "yellowish", glabrous; tube somewhat longer than the calyx, more or less constricted above the middle; the lobes suberect, ovate, obtuse, about $1 \mathrm{~mm}$. long. Anthers subsessile, inserted at the very base of and about as long as the corollalobes, ovate, apiculate, not or scarcely exerted. Ovary depressed-globose, more or less 5-lobed, shortly pilose, contracted into the glabrous, obtuse, cylindrical style which is up to about twice as long as the ovary. Berry subsessile, cylindrical-ovoid or cylindricoblong, pointed (more or less shaped like an acorn), crowned with the persistent style. $2-2 \cdot 5 \mathrm{~cm}$. long and $1-1 \cdot 5 \mathrm{~cm}$. in diam., deep red when ripe (? also sometimes transparent white, Sim) minutely pubescent, one-seeded, edible. Seed ellipsoid-oblong, $\pm 20 \mathrm{~mm}$. long, $\pm 8 \mathrm{~mm}$. wide, and $5 \mathrm{~mm}$. thick in the centre. with a long $-2.4 \mathrm{~mm}$. wide scar occupying the whole ventral side of the seed; testa thin, brittle.

Distribution.--In frostless forests in the Eastern Cape Province and Natal. from East London and Komgha northwards, also recorded from the central Transvaal. Portuguese East Africa and the eastern part of Rhodesia, and extending into tropical East Africa as far as Tanganyika or perhaps Uganda. 
The type (not seen) is Gueinzius 181 from Berea nr. Durban, Natal(in herb. Sonder). This same number is cited by Harvey ex Wright in Fl. Cap. 4, 1: 437, together with Sanderson 657, Wood 732 and a few other gatherings. Engler (1904) cites Gueinzius 181 and Medley Wood 8950. The specimen Wood 732 and Engler's fiôure levve no doubt about its identity.

Cape Province.-East London: near East London, Galpin 9284 (PRE), 9677 (PRE). Komgha: Flanagan 1138 (GRA, PRE, BOL, SAM). Pondoland: Egossa, Sim 2374 (NU, GRA, PRE, BOL, SAM). Kentani: Pegler 859 (GRA, PRE, BOL, SAM, NBG); Manubi Forest, Story 4475 (PRE). Willowvale: Acocks 12284, 12286 (PRE). Ngqeleni: Notinsella, FD herb. No. 1728 (SAFD); Gokama Forest: Marais 758. Port St. Johns: O. B. Miller D/88=FD herb. No. 3864 (SAFD); Noxolweni Forest, Mogg 13089 (PRE).

NaTAL.-Umzinto: Dumisa, Rudatis 964 (L). Pietermaritzburg: Killick 308 (PRE). Durban: Sanderson s.n. (=657?) (PRE), Wood s.n. BOL, SAM = prob. Inanda, Wood 732, GRA); Marriott PS 230 (PRE), Thorns s.n. (NH no. 23407), Lavoipierre 94 (NU). Eshowe: Lain 57 (NH), Gerstner 1920 (NU. PRE), Forbes 681 (NH), Codd 1860 (PRE). Hlabisa: Hluhluwe Game Reserve, Codd 2050, Ward 1692 (PRE). "Zululand": Gerstner 2618 (BOL).

Transvaal.-Pilgrims Rest: Mariepskop, Killick \& Strey 2496 (PRE).

SWAZILAND.-Miller S. 263 (PRE).

TANGanyika.-Devern: Burtt s.n. (J); Zigigler (or Zigiglen): Burtt s.n. (J), East Usambaras: Mlinge-Tongwe: Greenway 6064.

Two specimens from Uganda (Greenway 6064 and Greenway \& Eggeling 7076 in EA and PRE) are very similar if not conspecific. Two species described from E. Africa, viz. Chrysophyllum holtzii Engl. et Krause in Engl. Bot. Jahrb. 49: 390 (1913), and C. tessmannii Engl. et Krause (op. cit., p. 389) may well be synonyms of Pouteria natalensis.

As regards its taxonomical position, Engler placed $P$. natalensis in the subgenus or section Gambeya (Pierre) Engl. (= Afrochrysophyllum Engl. p.p.) of Chrysophyllum, but this species has several features which distinguish it from Gambeya: according to Engler's diagnosis of Gambeya (Engler, op. cit., p. 43), the stamens are inserted at or below the middle of the corolla-tube " Staminum filamenta ad basin tubi vel medio libera "), the corolla lobes are ciliate (Corollae tubus lobis ciliatis aequalis vel longior") and the nervation of the leaves is different: (". . nervis lateralibus I pluribus numerosis arcuatim patentibus prope marginem sursum versis, nervis lateralibus II inter primarios obliquis"). The fruit is also different ( 1 -seeded in $P$. natalensis, usually several-seeded in Gambeya, the seed-scar occupying the whole ventral side of the seed in $P$. natalensis, only the greater part of the ventral side in Gambeya) and, finally the ovules are basolaterally attached in Gambeya and distinctly laterally in $P$. natalensis. I cannot refer $P$. natalensis to any other African genus but Pouteria on account of the fruit characters (thin testa, large scar and lack of endosperm), in spite of the apparently constant absence of alternipetalous staminodes (which would not, however, exclude it from Pouteria sensu Van Royen).

Although most modern authors do not agree with Baehni's very broad conception of the genus Pouteria, several tropical species which fall into Pouteria sensu Van Royen were either overlooked, or expressly excluded from the genus by Baehni. I cannot see why these species were omitted or excluded, as Baehni did not give any reasons for his actions. It seems necessary to make the recombinations in Pouteria, because it may guide future workers on the flora of tropical Africa as regards my conception of the genus. This list is not complete, for only those species are included which could be studied from authentic herbarium specimens or from good plates. 
Pouteria adolfi-frederici (Engl.) A. Meeuse, comb. nov. Sideroxylon(?) Adolfi-frederici Engl. in Mildbr., Wiss. Ergebn. deut. Zentral-Afr. Exp. 1907-1908. 2: 519. t. 52 (1913). Aningeria adolfi-frederici (Engl.) Robyns \& Gilbert in Robyns, Fl. Spermatophyt. Nat. Parc Albert 2: 43 (1947).

The plate and a duplicate of a syntype (named by Engler), viz., Mildbraed 2528 (PRE), were available for study. There is no doubt that it is a Pouteria.

Pouteria cerasifera (Welw.) A. Meeuse, comb. nov. Sapota cerasifera Welw.. Apontam. 585. No. 17 (1859). Chrysophyllum cerasiferum (Welw.) Hiern. Cat. Afr. Pl. Welw. 3: 643 (1898). Sersalisia cerasifera (Welw.) Engl.. Mon. Sapot Afr. 30 (1904).

Pouteria disaco (Hiern.) A. Meeuse, comb. nov. Chrysophyllum disaco Hiern, Cat. Afr. Pl. Welw. 3: 642 (1898). Sersalisia disaco (Hiern) Engl., Mon. Sapot. Afr. 30 , t. 10A (1904).

Mr. B. de Winter compared a few specimens from Portuguese East Africa with authentic material (Welwitsch 4812 in BM). Some of these are in fruit and can. therefore, be referred to Pouteria sensu Van Royen.

Pouteria msolo (Engl.) A. Meeuse, comb. nov. Chrysophyllum msolo Engl., Pflanzenw. O. Afr. C., 306, t. 37 (1895). Pachystela msolo (Engl.) Engl., Mon. Sapot. Afr. 38 (1904).

This plant is so closely related to "Pachystela brevipes" that Engler did not hesitate to refer it to Pachystela and it is altogether incomprehensible to me how Baehni could exclude Pachystela msolo (in Candollea 9: 428), while referring P. brevipes to Pouteria (op. cit., 291). The same applies to the following species which is also very similar to P. hrevipes and yet excluded by Baehni (op. cit., 428) from Pouteria.

Pouteria zenkeri $A$. Meeuse. nom. nov. Pachystela rohusta Engl. in Engl. Bot. Jahrb.

49: 386 (1913), non Pouteria rohusta (Mart. et Eichl.) Eyma.

A true isotype. named by Engler, viz. Zenker 3697 (in PRE) was studied. The specific epithet "robusta" being preoccupied on account of an earlier combination for an American species, the name "zenkeri" was chosen to commemorate its first collector, well-known for his extensive West-African collections. It is strange that no reference is made to this Cameroons species in Hutchinson and Dalziel's Fl. W. Trop. Afr. vol. 2 under Sapotaceae.

\section{VINCENTELLA}

Pierre, Not. botan. Sapot. 37 (1891). Bakerisidero.yylon Engl. (as a section of Sider$o x y / o n)$ in Engl. u. Prantl, Natürl. Planzenfam. ed. 1. 4. 1: 144 (1890), and in Nachträge 276 (1897); (as a genus) in Mon. Sapot. Afr. 33 (1904).

Sideroxylon sensu Baker in Oliv., Fl. Trop. Afr. 3: 502 (1877), pro parte.

Bakeriella Dubard in Lecomte, Not. Syst. 11: 89 (1911) and in Ann. Mus. Col. Marseille 20: 26 (1912), pro parte.

Pouteria Aubl. sectio Bakerisideroxylon (Engl.) Baehni in Candollea 9: 382 (1942).

Type species: Baehni, in Candollea 7: 497 (1938), p. 497, mentions as the type species Vincentella longistyla (Baker) Pierre, Not. Bot. Sapot. (1891), p. 37. However. this is a synonym of Pachystela brevipes and as Pachystela was only validly published in 1904, V. longistyla at the same time being removed from Vincentella and transferred to Pachystela by Engler, the type species of Vincentella must be among the other two species mentioned by Pierre and retained in Bakerisideroxylon by Engler. viz.. V. densifora (Baker) Pierre and V.revoluta (Baker) Pierre. Priority of place would indicate Sideroxylon densiflorum Baker $=$ Vincentella densiffora (Baker) Pierre (from San Tomé Island) as the type species, as was rightly pointed out by Exell in Cat. Vasc. 


\section{Pl. S. Tomé 235 (1944).}

Shrubs or trees. Leaves generally oblong, with usually rather distant prominent secondary nerves and fine tertiary reticulate nervation. Stipules early deciduous. Flowers small, 5-merous, in many-flowered fascicles in the leaf axils and especially in the axils of fallen leaves on the twigs; pedicels very slender to capillary often rather long and more or less pendulous. Sepals small, free nearly to the base, later patent or reflexed. Corclla-tube very short, the lobes many times longer, elongateoblong or linear-oblong, strongly reflexed. Staminodes and stamens inserted at the throat of the corolla-tube. Alternipetalous staminodes narrowly linear, inserted between and about as long as the corolla-lobes (but erect), entire or rarely dentate-serrate, acute or acuminate. Filaments filiform, erect, several times longer than the oblong-sagittate, minutely apiculate anthers. Ovary large, ovoid, villous, contracted in the usually rather long and filiform-cylindric, glabrous style, 5-loculated; ovules with lateral attachment, pendulous. Fruit oblong-ovoid, 1-seeded with 4 sterile loculi. Seeds oblong; testa crustaceous; scar long, linear, occupying the upper part of the ventral side of the seed; cotyledons thick and fleshy, endosperm membranous or absent.

An African genus of four spec!es, on species extending into Southern Africa.

As Baehni, l.c. pointed out, Vincentella Pierre (1891) was legitimately published as a genus, although it corresponded with a section Bakerisideroxylon (1890) distinguished by Engler in the genus Sideroxylon which was later (1904), given the status of a genus by Enger. Pierre was not compelled to take up Engler's section name when he established a new genus and Vincentella, therefore, stands.

The typical slender pedicels, reflexed narrow corolla-lobes and very short corollatube, the fairly large ovary, erect long anthers and long staminodes make it possible to recognise a species of Vincentella almost at once. Baehni retains Vincentella as a section Bakerisideroxylon of his large genus Pouteria Aubl. sensu Baehni, but it is so distinct that, in my opinion, it deserves generic rank.

V. sapinii (De Wild.) Brenan in Mem. New York. Bot 8: 498 (1954).

Bakerisideroxylon sapinii ("Sapini") De Wild. in Rev. Zool. Afr. 7, suppl. bot. B 16 (1919), and in Pl. Bequart. 4: 116 (1926), type: Sapin s.n. BR, holo.; K, iso.

Pouteria tridentata Baehni in Candollea 9: 386 (1942); type: Stolz 1889 from Tanganyika in $\mathrm{G}$, holo; $\mathrm{K}$ and PRE, isos.

Bakerisideroxylon stolzii Mildbr. Ms.

Vincentella stolzii (Mildbr. Ms. ex) Hutch., Botan. South Afr. 506 (1948), nomen nudum.

General Distribution.--Southern Tanganyika. Nyasaland and the Niassa Province of Portuguese East Africa, Northern Rhodesia and Belgian Congo, seems to prefer streambanks (teste Gomes e Sousa, Benson, Brass). (PRE).

Nyasaland.-Kota-Kota distr.: Benson 257, 765 (PRE); Chia area, Brass 17510 (PRE).

Portuguese E. Africa.-Niassa: Nampula distr., Ribáué, Gomes e Sousa 2305

Tanganyika Territory.-Kyimbila: Stolz 1889 (isotype of Pouteria tridentata Baehni, PRE).

"A shrub or small tree, 4-6 m. high". (Gomes e Sousa). Young branches terete, densely rusty-tomentose-hirsutulous, later becoming shortly and more greyish-tomentose, the older ones ultimately glabrescent. Leaves oblanceolate-oblong to obovate-oblong, 
with obtuse, rounded or emarginate apex and attenuated-cuneate base, with reflexed margin, 4-10 cm. long, 3-5 cm. wide (according to Baehni: $10-14 \mathrm{~cm}$. long and 3-5 $\mathrm{cm}$. wide), chartaceous or subcoriaceous, soon glabrous, rather shiny above. paler and duller beneath; midrib impressed and keeled above, very prominent and when dry longitudinally sulcate below, glabrescent but retaining the original tomentum somewhat longer than the rest of the blade; secondary nerves impressed above, prominent below, $8-12$ on either side, rather distant $(4-10 \mathrm{~mm}$. apart), at first rather straight, ascending at an angle of $45^{\circ}-70^{\circ}$, arcuate-ascending near the margin and reaching it except those near the apex; tertiary nerves inconspicuous above, subimpressed and rather distinct below, slender, mainly perpendicular to the secondary ones; ultimate nervation very fine reticulate, tessellate, rather distinct at least below. Petioles stout, densely rusty-tomentose-hirsutulous, $3-10 \mathrm{~mm}$. long, flattened and canaliculate above, Stipules linear-subulate 4-5 mm. long, deciduous. Flowers fragrant (teste Benson). Pedicels 5-7.5 mm. long, hirsute, terete, slightly widening under the calyx. Sepals ovate-triangular, hairy outside glabrous inside, about $1 \frac{1}{2} \mathrm{~mm}$. long. Corolla white (teste Gomes e Sousa and Benson) glabrous, lobes narrowly-oblong, obtuse, $-3 \mathrm{~mm}$. long $1 \mathrm{~mm}$. wide. Staminodes linear, acute, about as long as the corolla-lobes, with or a few small or minute lateral teeth. Filaments slender, $2 \cdot 5-3 \mathrm{~mm}$. long, the anthers $0.5 \mathrm{~mm}$. long. Ovary ovoid-conical, hirsute, $=1 \frac{1}{2} \mathrm{~mm}$. long and $1 \mathrm{~mm}$. in diameter, attenuated into the long-subulate-linear, sulcate (at least when dry), subacute and glabrous $1 \frac{1}{2}-2 \mathrm{~mm}$. long style. Fruit and seed not seen but fruit reported by Brass to be yellow, soft and edible.

\section{LECOMTEDOXA}

(Engl.) Dubard in Ann. Mus. Col. Marseille 23: 31 (1915); Baehni in Candollea 7: 456 (1938); Lam in Blumea 4: 348, 350 (1941).

Mimusops subgenus Lecomtedoxa (Pierre ex) Engl., Mon. Sapot. Afr. 82, t. 24. Fig. A. (1904).

Mimusops subgenus Quaternaria sectio Inhambanella Engl., op. cit.. 80; Pilger in Engler \& Prantl, Natürl. Pflanzenfam., ed. 1, Nachträge 1897-1904), exclus. descr. of the flowers.

Inhambanella (Engl.), Dub., tom., cit., 42, as to type species.

Type species.-Mimusops kleiniana Pierre ex Engl., Mon. Sapot. Afr. 82 (1904) =Lecomtedoxa kleiniana (Pierre ex Engl.) Dub. in Ann. Mus. Col. Marseille 23: 31 (1915).

Small to very large trees. Leaves more or less distinctly crowded at the tips of the branchlets, coriaceous, more or less shiny above, paler and dull beneath. Flowers in few to many-flowered fascicles in the axils of the leaves or of leaf-scars below the leaves. Calyx-lobes 4-6; sometimes 3, sometimes unequal and subbiseriate, more or less erect. more or less concave. Corolla isomerous with the calyx; the tube short to rather long the lobes with each 2 lateral appendages (sometimes with only one appendage); the appendages entire, either very broad and larger than the lobes, or small. Alternipetalous staminodes lanceolate to ovate-lanceolate or long-triangular (resembling those of Sideroxylon), rather large and conspicuous, alternating with the corolla lobes. Stamens inserted in the throat of the corolla-tube or slightly higher up; filaments short or rather long; anters apiculate. included or slightly exserted. Ovary 5(-6)loculate, hairy; ovules with lateral attachment; style glabrous, rather short, either capitate or tapering at the apex. Fruit 1-seeded, rather large. Seed with long scar occupying the ventral side of the seed; testa crustaceous; endosperm $\mathrm{O}$ or very thin; cotyledons thick and fleshy. 
General Distribution.-2 or 3 species in tropical West Africa, one in Portuguese East Africa and Zululand.

L. henriquesii (Engl. et Warb.) A. Meeuse, comb. nov.

Mimusops henriquesii Engl. et Warb. in Engl., Mon. Sapot. Afr. 80 (1904), (sphalm. "henriquezii", cf. "Corrigenda ", op. cit., p. 88); type: Rolla Ferreira s.n. from Portuguese East Africa in COI, holo! M. henriquesiana (Sphalm.?) Sim. For. Fl. Port. E. Afr. 80, t. 77, A (1909); Gerstner in J. S. Afr. Bot. 12: 54 (1946).

Inhambanella henriquesii (Engl. et Warb.) Dub. in Ann. Mus. Col. Marseille 23: 42 (1915).

As Engler's and Sim's descriptions are very incomplete and the flowers had hitherto not been known, a very detailed description is given.

Small to medium-sized tree, up to $20 \mathrm{~m}$. high, with spreading branches and abundant heavy foliage. Branches rather stout, terete, longitudinally striate and sulcate. soon quite glabrous, greyish-born, later turning light grey and usually marked with scars. Innovations rusty-tomentose, but vegetative parts soon quite glabrous. Stipules subulate-falcate, pubescent, 3-7 mm. long, early deciduous. Petioles rather strongly canaliculate above and with a very narrow dorso-lateral wing or ridge on either side (which is a continuation of the edges of the decurrent leaf-base), when dry longitudinally sulcate, 12-35 (-52) mm. long. Young growths bright red to red-brown. Leaves varying from oblanceolate-oblong to oblong or obovate-oblong, obovate or broadly elliptic, coriaceous but rather thin, green (drying pale green or greyish green), 5-12 $(-17) \mathrm{cm}$. long and $2 \frac{3}{4}-5(-8) \mathrm{cm}$. wide, with obtuse, rounded or bluntly acuminate, often distinctly emarginate and more or less deflexed apex, acute or somewhat attenuate and slightly decurrent at the base, with reflexed margin, the edges often more or less undulate; almost invariable some leaves of each specimen with raised round flat or semiglobose galls; midrib impressed and keeled above, very prominent and when dry longitudinally sulcate below; secondary nerves 6-9 on either side, rather distant (5-10 mm., sometimes up to $25 \mathrm{~mm}$. apart), not very conspicuous and often subimpressed (but sometimes slightly raised) above, usually prominent and more conspicuous below, slender, at first patent (ascending at angles between $45^{\circ}$ and $90^{\circ}$ ), but mostly soon arcuate-ascending, the majority very strongly curved, becoming more or less sinuous and parallel with the edge of the leaf, ultimately reaching the nerve above it and thus forming a more or less distinct intra-marginal vein close to the margin, but some bifurcate or archingly joining; tertiary nerves more or less perpendicular to the midrib and joining the secondary ones, forming a coarse reticulation which is slightly prominent below; ultimate nervation very fine, reticulate, usually conspicuous at least on the lower surface. Flowers in few to many-flowered fascicles; bracts ovate, usually strongly concave to almost keeled and acute, 1-3 mm. long, pubescent; pedicels 5-20 mm. but usually $10-15 \mathrm{~mm}$. long, terete or slightly angular, brownish-tomentose, rather abruptly widening into the calyx. Sepals 5 (or 4 to 6) erect, more or less concave, 4-5 $\mathrm{mm}$. long, unequal to sub-biseriate; the outer 2-3 ovate-triangular from a broad base, 3-4 mm. wide, subacute, brownish-tomentose outside and inside near the margin and towards the apex; the inner ones thinner in texture, ovate-oblong, elliptic or broadly

FIG. 8.-Lecomtedoxa henriquesii, 1: Flower, x 5; 2: outer sepal; 3: inner sepal; 4: corolla tube, opened and seen from inside, $\mathrm{x} 10 ; 5$ : part of corolla tube seen from outside, showing the lateral appendages, $x 10 ; 6$ : ovary. $x 10,7$ : fruit and 8: seed ( 7 and 8 from the type specimen, Ferreira s.n. in COI). 


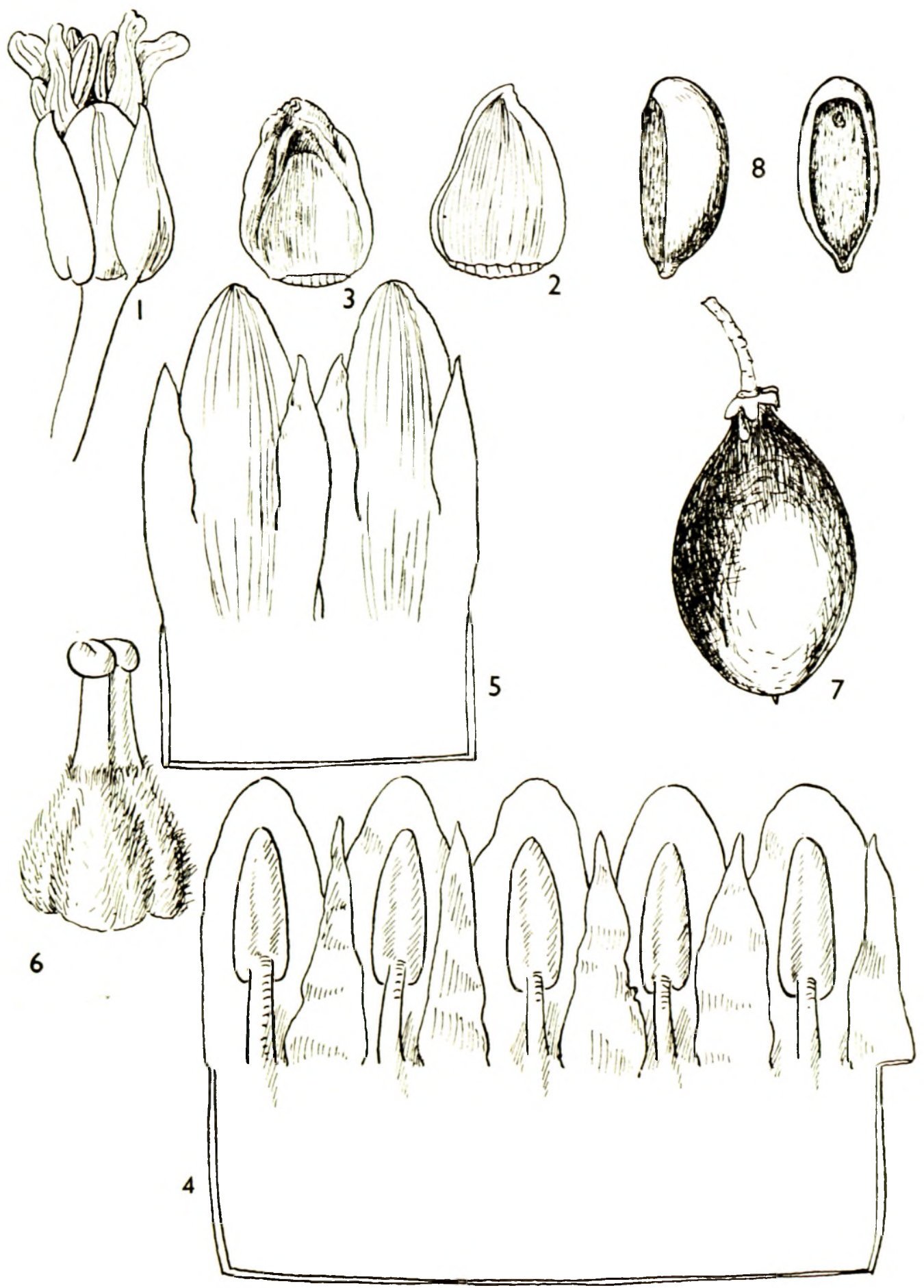


oblong, with a narrower base, obtuse or rounded at the apex. pale fawnish-tomentosesericeous outside, glabrous inside, finely ciliate along the margin, usually only $2-3$ $\mathrm{mm}$. wide. Corolla glabrous, yellowish or white; the tube cylindric-campanulate, about $3 \mathrm{~mm}$. long, the inside with distinct thickened lines below the stamens and the staminodes; the lobes elliptic or elliptic-oblong, $4-4.5 \mathrm{~mm}$. long, and 2-3 $\mathrm{mm}$. wide; lateral appendages shorter than or as long as the corolla-lobes, attached near the middle of the corolla-lobes or near the base, usually asymmetrical, ovate-lanceolate to lanceolatefalcate, 1-4 mm. long. Alternipetalous staminodes ovate-lanceolate or lanceolate to elongate-triangular, often somewhat undulate, entire, acute, or obtuse, glabrous, about $3 \mathrm{~mm}$. long. Stamens inserted on the corolla-lobes slightly above the throat of the tube; filaments linear, $1-2.5 \mathrm{~mm}$. long, glabrous, more or less winged and often with broad somewhat auriculate base; anthers oblong. minutely apiculate, $1 \cdot 5-2 \cdot 5 \mathrm{~mm}$. long. Orary ovoid-conical, about $1.5 \mathrm{~mm}$. long and 1.5-2 $\mathrm{mm}$. in diameter, more or less distinctly lobed, densely greyish-tomentose, usually 5-loculated; style glabrous, thick, columnar, terete or somewhat angular, about $1.5 \mathrm{~mm}$. long and $0.5 \mathrm{~mm}$. thick; stigma capitate, indistinctly 5-lobed and sometimes also bilobed. Fruit ellipsoid, about $4 \mathrm{~cm}$. long and 2-2.5 cm. in diameter. Seed oblong, somewhat compressed, about $3 \mathrm{~cm}$. long, $1.5 \mathrm{~cm}$. wide and $1 \cdot 2 \mathrm{~cm}$. thick; testa crustaceous, shiny, scar oblong, about $28 \mathrm{~mm}$. long and $6 \mathrm{~mm}$. wide; cotyledons about $5 \mathrm{~mm}$. thick.

Zululand.--Hlabisa: False Bay (according to Gerstner, 1.c.; no specimen seen); St. Lucia Estuary, Ward 441 (NU); Mdlozi Peninsula, Ward 3032 (PRE).

Portuguese E. Africa.-Sul do Save: Maputoland, Santaca; Gomes e Sousa 3816 (COI, PRE). Manica e Sofala: Inhambane, Rolla Ferreira s.n. (COI, type ); Beira, Vila Fontes, leg. N.N., Labóratorio Quimico Herbario No. 77 (SRGH); Chissadze, Cheringoma, Simão 1559 (PRE); Dondo Junction. Honey 871 (BOL, PRE). Zambezia: Quelimane, between Mopeia and Morzumbala, Barbosa \& Carvalho 3960 (PRE). Locality not known to me (near Inhambane?): Maguiya da Costa, Sim 20911 (PRE).

The type is a specimen leg. A. J. Rolla Ferreira in 1903 (s.n.), "Regiões de Gaza e Inhambane", but most probably from Inhambane, Portuguese East Africa, because Engler named it "Inhambanella" and Sim (l.c.) mentions "Ferreira's farm near Inhambane" as the place of origin. Engler erroneously mentioned: "Herb. Univ. Cordoba" instead of "Herb. Univ. Coimbra " as the location of the type specimen. Sim refers to this plant as "Mimusops henriquesiana" but as he mentions Ferreira's farm and the specific epithet is so similar, I am of the opinion that "henriquesiana" is a lapsus calami for "henriquesii".

As regards the identity of Mimusops henriquesii and the other specimens cited above, the only fruiting specimen that I could study was the type, but the vegetative parts and the calyx agree in every respect with those of the flowering specimens cited here so that I feel certain that the identification is correct.

The species under discussion differs from the West African representatives of Lecomtedoxa, in that the lateral appendages are small and the fruit is only slightly attenuate near the base (in the W. African species the lateral appendages are larger than the corolla-lobes, and the fruits are markedly attenuate at the base). In all other essential characters, the South African species agrees very well with the West African ones, such as the structure of the calyx, the staminodes, the attachment of the ovules, the one-seeded fruit, and the seeds with long ventral scar and without (or with very scanty) endosperm. I see no reason to create a separate genus nor even a subgenus or section for the South African species, because the differences are only relative ones and, in my opinion, not at all important. 
Lecomtedoxa is a remarkable genus in that it combines the possession of lateral appendages with (usually) 5-merous flowers, a monoseriate calyx (which, however, tends to be biseriate) and seeds with long scar (ovules with lateral attachment), and it forms a veritable link between the subfamily Mimusopoidea $\mathrm{H}$. J. Lam (with biseriate calyces and 3-merous or 4-merous flowers) and the subfamily Sideroxyloideae H. J. Lam (with usually 4-merous flowers, and monoseriate calyx); especially the tribe Pouterieae H. J. Lam (which also has long seed-scars). The only other genera in which 5 -merous flowers are found, combined with the presence of lateral appendages and monoseriate calyx, are the American genera Bumelia and Dipholis, of the Sideroxyloideae-Bumelieae. These two genera show great affinities to the genus Sideroxylon and certainly deserve their place in the Sideroxyloideae. Lecomtedoxa on the other hand, shows distinct affinities with the Mimusopoideae (subbiseriate calyx) and should, in my opinion be retained in this subfamily as was done by Dubard and by Lam.

In a note on Ward 3032 the collector mentions that the young growths (young leaves) are bright-red to red-brown which makes the trees quite conspicuous in spring.

\section{AUSTROMIMUSOPS}

A. Meeuse, gen. nov. Inhambanella Dubard, in Ann. Mus. Col. Marseille 23: 42 (1915), pro parte, non Mimusops Subgenus Quaternaria sectio Inhambanella Engl. in Mon. Sapot. Afr. 80 (1904). Mimusops Auct., pro parte.

Arbores vel frutices. Folia chartacea vel subcoriacea, conspicue ad apices ramulorum conferta; foliorum nervi secundarii et tertiarii atque venae tenuae, dense subtiliter reticulates. Flores 1-4 in axilis ad apices ramulorum (3-) 4 meri. Sepala (3 +3 vel) $4+4$, rarissime $5+5$, elongata-triangularia vel lineari-oblonga vel linearilanceolata exterioribus et interioribus subaequilongis extus tomentosis, acutis vel interioribus obtusis, interioribus pallidioribus. Corollae tubus brevis; segmenta (6-) 8 appendiculis binis integris instructa. Stamina fertilia (6-) 8, staminus filamenta antheris breviora; antherae oblongo-lanceolatae vel lanceolatae connectivo apiculato. Staminodia elongata-triangularia vel lanceolata, integra vel interdum ad apicem plus minusve dentata, extus pilosa. Ovarium ovoideum vel subglobosum, hirsutum (6-) 8 loculare; ovula ad medium loculorum vel basi-laterale affixa; stylus exsertus, cylindratus vel subulatus vel filiformis, glabrus. Вacca ovoidea vel ellipsoidea, apiculata, monosperma raro 2-sperma. Semen ellipsoideum; area derasa (= cicatrix) magna, lata, semen longitudine subaequalis; testa crustacea vel plus minusve pergamacea; albumen nullum; cotyledones plano-convexae, crassae.

Type species: Mimusops marginata N. E. Br. (=M. natalensis Schinz non Engl.) $=$ Austromimusops marginata (N.E. Br.) A. Meeuse.

Large shrubs or small to medium-sized trees with the leaves crowded at the very tips of the, often thick, branches. Leaves exstipulate, firm, but usually not coriaceous, not very shiny above, with a very fine tessellated reticular nervation which is always conspicuous at least on one side. Petioles distinctly, and usually widely, canaliculate above. Flowers in the axils of the leaves or of scaly bracts, 1-4 together, but as the leaves are crowded at the tips of the branches, apparently forming dense umbels of up to 20 flowers and over. Pedicels usually more or less pendulous. Calyx biseriate, the lobes free nearly to the base, $(3+3$ or) $4+4$, very rarely $5+5,3$ - and $4-$, or $4-$ and 5 - merous calyces occuring in one specimen; outer calyx lobes thicker and usually broader than the inner ones, which also differ in pubescence and are more or less distinctly midribbed. Corolla 3-merous and 4-merous (also occasionally 5-merous?) in one specimen, or 4- merous; the tube very short; the lobes and lateral appendages subequal. Stamens (6 or) 8, resembling those of Mimusops, i.e., the anthers longer 
than the filaments, apiculate. Staminodes as in Mimusops, i.e., not deeply incised, lobed or fimbriate, usually quite entire, concave, hairy outside. Ovary 6- or 8- loculated, usually subglobose; ovules with lateral or sometimes basi-lateral attachment; style terete, subacute or subtruncate at the apex. Fruit one-seeded, rarely 2-seeded. Seed with rather thin, crustaceous or tough almost pergamaceous testa and a large broad scar occupying nearly the whole ventral side of the seed; endosperm absent; cotyledons thick and fleshy.

The genus contains at least four species, three found in Southern Africa, and one in tropical East Africa.

Engler, 1.c., based his section Inhambanella of Mimusops on a specimen without flowers, mainly on the characters of the seed. Dubard, l.c., noticed that the ovules of the species Mimusops natalensis Schinz non Engl. ( Mimusops marginata N.E. Br.)

are laterally attached and concluded that these ovules would give rise to seeds with a long lateral scar, so that this species could not be a true Mimusops. Although Dubard did not study the type specimen of Mimusops henriquesii (the type of Engler's section Inhambanella), he referred Mimusops natalensis Schinz to Inhambanella, which he raised to generic rank. This was a conjecture, because the flowers of $M$. henriquesii were unknown and Dubard had not seen the seed of $M$. natalensis Schinz.

However, Mimusops henriquesii is, in my opinion, a species of Lecomtedoxa (see p. 344) and therefore, the name Inhambanella either as a subgenus or as a genus being typified by Mimusops henriquesii Engl. et Warb., becomes a synonym of the genus Lecomtedoxa (Engl.) Dub. Dubard was, to my mind, quite right in excluding $M$. natalensis Schinz from Mimusops, but the name Inhambanella Dub. cannot be used for it and the congeneric forms, included here in Austromimusops. The affinities of Austromimusops are most probably with Baillonella Pierre which it resembles in floral characters, which are also very similar to those of Mimusops, but from which it differs in the absence of endosperm (Baillonella has a thin layer of endosperm), and the thin crustaceous to pergamaceus testa (thick and bony in Baillonella), and with the more or less dubious genera Dumoria Chev. and Tieghemella Pierre (=- ?Dumoria).

Although the floral characters are very similar to those of Mimusops, there are so many differences that the generic distinction is not very difficult. The vegetative characters alone are almost sufficient to typify Austromimusops, apart from the characters of the seed. The following table (see Table II) shows the differences between the genera Mimusops s.s., Austromimusops, Baillonella and Manilkara. Dumoria and Tieghemella are not included, because it is very likely that they are identical with Baillonella, at any rate the characters of fruit and seed are apparently the same as those of Baillonella.

Leaves usually more than $6 \mathrm{~cm}$. long, petiole usually over $10 \mathrm{~mm}$. long. Pedicels $2-5 \mathrm{~cm}$.

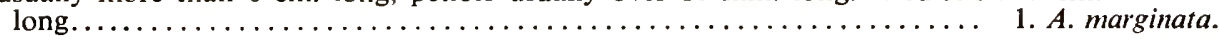

Leaves (at least the majority) under $6 \mathrm{~cm}$. long, petiole $3-8 \mathrm{~mm}$; rarely up to $10 \mathrm{~mm}$. long. Pedicels $0 \cdot 9-2 \mathrm{~cm}$. long:

Young parts, pedicels and calyces buffy-brown pubescent. Leaves $\frac{3}{4}-2\left(-2 \frac{1}{2}\right) \mathrm{cm}$. wide, soon quite glabrous. Petioles soon glabrous. Pedicels $9-16 \mathrm{~mm}$. long. Calyxlobes $5-6 \mathrm{~mm}$. long. Natal. ........................ dispar.

Young parts, pedicels and calyces rusty-pubescent. Leaves $1 \frac{1}{2}-3 \frac{1}{2}\left(-4 \frac{1}{2}\right) \mathrm{cm}$. wide, often showing vestiges of the rusty brown pubescence. Petiole often rusty-tomentose. Pedicels usually $1 \frac{1}{2}-2 \mathrm{~cm}$. long. Calyx-lobes $7 \mathrm{~mm}$. long. E. Southern

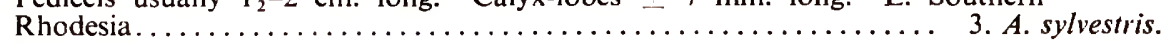

1. A. marginata (N.E. Br.) A. Meeuse, comb. nov.

Mimusops marginata N.E. Br. in Kew Bull. 108 (1895); Engl., Mon. Sapot. Afr. 71 (1904); Wright in Dyer, Fl. Cap. 4, 1: 441 (1906); Sim, For. Fl. Cape Col. 254, pl. 97. Fig. 1 (1907); Gerstner in J. S. Afr. Bot. 12: 54, Figs. 8, 9 (1946); type: Flanagan 27, K, lecto., BOL, GRA, NBG, PRE. isos! M. natalensis Schinz in Bull. 
TABLE II

\begin{tabular}{|c|c|c|c|c|}
\hline & Mimusops. & Austromimusops. & Baillonelli. & Manilkara. \\
\hline 1. Leaves........... & $\begin{array}{l}\text { Scattered on the branches, } \\
\text { coriaceous, smooth and } \\
\text { shiny above, exstipulate. }\end{array}$ & $\begin{array}{l}\text { Terminal on the branches } \\
\text { firm but usually not coria- } \\
\text { ceous, not smooth and } \\
\text { rather dall above, exstipu- } \\
\text { late. }\end{array}$ & $\begin{array}{l}\text { Terminal on the branches, } \\
\text { subcoriaceous, very large, } \\
\text { smooth and shiny above, } \\
\text { stipulate. }\end{array}$ & $\begin{array}{l}\text { Almost invariably } \pm \text { terminal } \\
\text { on the branches, coriaceous } \\
\text { or not, smooth and shiny } \\
\text { above or dull } t \text { and rough, } \\
\text { exstipulate. }\end{array}$ \\
\hline 2. Nervation......... & $\begin{array}{l}\text { Various but not distinctly } \\
\text { parallel and rather lax with- } \\
\text { out a very fine areolat: } \\
\text { tessellate nervation }\end{array}$ & $\begin{array}{l}\text { Secondary nerves and tertiary } \\
\text { nerves rather few, ultimate } \\
\text { nervation very fine, tes- } \\
\text { sellate, distinct. }\end{array}$ & $\begin{array}{l}\text { Secondary nerves parallel, } \\
\text { numerous; ultimate nerva- } \\
\text { tion areolate, distinct. }\end{array}$ & $\begin{array}{l}\text { Secondary nerves usually } \\
\text { numerous, parallel, fine reti- } \\
\text { culate nervation often pre- } \\
\text { sent. }\end{array}$ \\
\hline 3. Calyx.......... & $\begin{array}{l}\text { Biseriate: always } 4+4 \text {, the } \\
\text { lobes rather long }(- \text { lanceo- } \\
\text { late) }\end{array}$ & $\begin{array}{l}\text { Biseriate: } 3+3,4 \text { or } \\
5+5 \text {, the same specimen } \\
\text { showing } 3-\text { and } 4 \text {-merous } \\
\text { calyces, the lobes as in } \\
\text { Mimmoss }\end{array}$ & $\begin{array}{l}\text { Biseriate, } 4-4 \text {, the lobes as } \\
\text { in Miliallsops }\end{array}$ & $\begin{array}{l}\text { Biseriate, usually } 3+3 \text {, some- } \\
\text { times } 4+4 \text {, or } 3 \quad 3 \text { and } \\
4-t 4 \text { on one specinien the } \\
\text { lobes relatively broad and } \\
\text { rather short. }\end{array}$ \\
\hline 4. Corolla.......... & $\begin{array}{l}8 \text { lobes }+8 \times 2 \text { lateral appen- } \\
\text { dages; appendages entire or } \\
\text { dissected. }\end{array}$ & $\begin{array}{l}6 \text { or } 8 \text { lobes with } 12 \text { or } i 6 \\
\text { appendages, respectively: } 3- \\
\text { merous and } 4 \text {-merous } \\
\text { flowers on one specimen: } \\
\text { appendages entire. }\end{array}$ & $\begin{array}{l}8 \text { lobes with } 8 \times 2 \text { appenda- } \\
\text { ges; appendages entire }\end{array}$ & $\begin{array}{l}\text { Usually } 6 \text { lobes }+6 \times 2 \\
\text { appendages; more rarely } \\
8+8 \times 2 \text {, appendages, } \\
\text { sometimes } 6+6 \times 2 \text { and } \\
8+8 \times 2 \text { in one specimen: } \\
\text { appendages entire; rarely } \\
\text { appendages } 0 \text {. }\end{array}$ \\
\hline 5. Stamens......... & $\begin{array}{l}\text { Stamens } 8 \text {, Filaments shorter } \\
\text { than the stamens, anthors } \\
\text { (rather) long ard narroti. }\end{array}$ & $\begin{array}{l}\text { Stamens } 6 \text { or } 8 \text {. Filaments } \\
\text { abd anthers as in Mimmsors }\end{array}$ & $\begin{array}{l}\text { Stamens } 8 \text {. Anthers and fila- } \\
\text { ments about as long, anthers } \\
\text { rather wide and rather short. }\end{array}$ & $\begin{array}{l}\text { Stamens } 6, \text { more rarely } 8 \text {, } \\
\text { sometimes } 6 \text { or } 8 \text { on one } \\
\text { specimen. Filaments usually } \\
\text { longer than anthers, the } \\
\text { latter relatively short. }\end{array}$ \\
\hline 6. Staminodes...... & $\begin{array}{l}\text { 8, entire or serrate at the apex } \\
\text { only, usually pubescent and } \\
\text { incurved so as to cover the } \\
\text { pistillum. }\end{array}$ & $\begin{array}{l}6 \text { or } 8 \text { (on one specimen), as in } \\
\text { Mimusors, entire or slightly } \\
\text { fimbriate at the pex, hairy } \\
\text { outside and incurved, } \\
\text { covering the pistillum. }\end{array}$ & $\begin{array}{l}\text { 8, widened at about } 1 / 3 \text { from } \\
\text { the base, hairy outside in the } \\
\text { basal part, upper part } \\
\text { spreading with the petals. }\end{array}$ & $\begin{array}{l}\text { 6, } 8 \text { or } 6 \text { and } 8 \text { sometimes less } \\
\text { short or long, but almost } \\
\text { invariably glabrous and laci- } \\
\text { niate, dentate, fimbriate or } \\
\text { dissected, erect with the } \\
\text { stamens or patent with the } \\
\text { petals. }\end{array}$ \\
\hline 7. Carpels and ovules & $\begin{array}{l}\text { Ovary } 8 \text { - (rarely } 16-\text { ) loculated; } \\
\text { ovules basally affixed. }\end{array}$ & $\begin{array}{l}\text { Ovaries can be 6-and 8-locu- } \\
\text { lated in one specimen; } \\
\text { ovules laterally affixed. }\end{array}$ & $\begin{array}{l}\text { Ovary 8-loculated; ovules } \\
\text { laterally attached. }\end{array}$ & $\begin{array}{l}\text { Ovary 15-6-loculated (usually } \\
6 \text { - loculated; in 4-merous } \\
\text { flowers 8-loculated), ovule } \\
\text { usually ventrally affixed, } \\
\text { more rarely almost basal. }\end{array}$ \\
\hline $\begin{array}{l}\text { 8. Fruit and seed } \\
\text { (cicatrix and testa) }\end{array}$ & $\begin{array}{l}\text { Fruit 1- to several-seeded; } \\
\text { scar almost invariably small, } \\
\text { circular and almost basal; } \\
\text { testa hard, bony, shiny. }\end{array}$ & $\begin{array}{l}\text { Fruit 1- seeded rarely } 2 \text {-seeded; } \\
\text { scar very large, ventral, } \\
\text { occupying the whole } \\
\text { length of the seed; testa } \\
\text { leathery or crustaceous, not } \\
\text { hard, dull }\end{array}$ & $\begin{array}{l}\text { Fruit l-seeded, large; scar } \\
\text { very large, occupying the } \\
\text { ventral halt of the seed; } \\
\text { testa thick, hard and bony, } \\
\text { shiny. }\end{array}$ & $\begin{array}{l}\text { Fruit } 1 \text { - to several-seeded scar } \\
\text { basiventral, relatively long } \\
\text { and narrow, more rarely } \\
\text { broader and ovate or } \\
\text { circular and almost basal, } \\
\text { testa usually hard, bony and } \\
\text { shiny, sometimes crusta- } \\
\text { ceous. }\end{array}$ \\
\hline $\begin{array}{l}\text { 9. Embryo and endo- } \\
\text { sperm }\end{array}$ & $\begin{array}{l}\text { Endosperm copious; cotyle- } \\
\text { dons thin, foliaceous. }\end{array}$ & $\begin{array}{l}\text { Endosperm } \mathrm{O} \text {; cotyledons } \\
\text { thick and fleshy. }\end{array}$ & $\begin{array}{l}\text { Endosperm thin; cotyledons } \\
\text { thick and fleshy. }\end{array}$ & $\begin{array}{l}\text { Endosperm copious; cotyle- } \\
\text { dons thin, foliaceous. }\end{array}$ \\
\hline
\end{tabular}



Herb. Boiss. 4: 441 (1896); type: Schlechter 6220 in Z. " M. transvaalensis Schinz" (sphalm.), Radlk. in Zahlbr., Pl. Penther. I, in Ann. K.k. Naturh. Mus. Wien 15: 63 (1900). M. schinzii Engl. op. cit., 70, t. 29, Fig. A; Wright, op. cit., 443, Gerstner, 1.c., 54 (same type as M. natalensis Schinz).

Inhambanella natalensis (Schinz) Dubard in Ann. Mus. Col. Marseille 23: 42 (1915).

A tree found in rather moist forests. Stem straight, 6-20 m. high and 30-60 cm. in diam. Branches terete, grey, more or less rough; ultimate branches short and rather stout, usually over $3 \mathrm{~mm}$. thick, often much thicker, glabrous. Innovations densely rusty tomentose-villous, but all vegetative parts soon quite glabrous. Leaves obovate or elliptic-obovate, sometimes elliptic-oblong or elliptic-(ob)lanceolate, thinly coriaceous with a dull shine (but not smooth) and drying a greyish green (rarely brown) above, paler and duller below, 3-15 (usually $6-13$ ) $\mathrm{cm}$. by $2-9 \mathrm{~cm}$., as a rule more or less acuminate with obtuse apex, a narrowed or somewhat rounded base and subreflexed margin; midrib distinct but not conspicuously keeled or channelled above, prominent below; lateral nerves slender but prominent beneath; ultimate nervation very fine, reticulate, usually conspicuous on at least one surface. Petioles (5-) 10-20 mm. long, rather stout, semi-terete. strongly and widely canaliculate. Flowers $1-3$ in axils of leaves and of scales inside them, more or less pendulous on $2-5 \mathrm{~cm}$. long pedicels, 3-merous or 4merous. Calyx biseriate, outer lobes rusty-pubescent, inner ones pale-pubescent, all acuminate, acute, $7 \cdot 5-12 \mathrm{~mm}$. long. Corolla dull white; tube 1-2 mm. long, pubescent outside, lobes and appendages subequal, 6-9.5 mm. long. Staminodes 6-8, densely villous outside, $4 \cdot 5-5 \cdot 5 \mathrm{~mm}$. long. Stamens 6-8 mm. long. Ovary 6- of 8 - celled; style $9-11 \mathrm{~mm}$. long. Fruit rather large, ovoid or ellipsoid, apiculate or attenuateapiculate, pointed, ultimately glabrous, purplish red, up to $5 \mathrm{~cm}$. long and $3 \frac{1}{2} \mathrm{~cm}$. diameter, on the slightly incrassate, but not lengthened pedicel; fruiting calyx spreadingreflexed. Seed broadly ellipsoid, 20-25 mm. long, about $20 \mathrm{~mm}$. wide and about $18 \mathrm{~mm}$. thick; testa crustaceous, dull, pale buff when dry; scar somewhat shorter than the seed, occyping about half its surface area, elliptic or oblong in out line, emarginate at the apex and about $20 \mathrm{~mm}$. broad in the widest place.

N. E. Brown did not designate a type specimen but Mr. de Winter informed me that the only specimen at Kew with fruits is Flanagan 27, so that most probably the fruits were described from this specimen. Accordingly, I propose Flanagan 27 (in K) as the lecto-type. Type locality: Komgha, E. Cape.

Distribution.-From East London northwards into Natal, Zululand and Portuguese East Africa, just crossing the Transvaal border.

Cape Province.-East London: Sim 2182, 2183, 2190 (= ?2194 collect. No.) (NU), 2194 (BOL), 2602, s.n. (PRE): Acocks 10979. 12298 (PRE), Courtney Latimer s.n. (PRE), Rattray 1371 (BOL). Komgha: Gwenkala, Flanagan 27 (PRE, GRA, BOL, SAM, isotypes); Schlechter 6220 (GRA, isotype of Mimusops natalensis Schinz $=$ M. schinzii Engl.). Kentani: Pegler 692 (PRE, BOL, NBG).

NATAL.-Port Shepstone: near Mehlomnyama, Marais 7871 (PRE). Umzinto: Dumisa, Rudatis 450 (L). Pinetown: Dellville, Smuts s.n. (NH No. 17830); Warner Beach, Ward 977 (NU, PRE); Amanzimtoti, Williams 65 (NU); Marianhill, Forbes 1041 (NH); Umlaas, Wood $5440(\mathrm{NH}) ;$ Kotze 436 (PRE) = FD Herb. No. 6858 (SAFD). Durban: Inanda, Wood $1661(\mathrm{NH})$. Camperdown: Hammarsdale, Forbes 310 (NH). Empangeni: Utimona, Gerstner 2748 (BOL, NH, PRE). Nongoma: Wendelane Kloof, Gerstner 4657 (NH, PRE, BOL, NBG). Hlabisa: Gerstner 3817 (NH); Hluhluwe Game Reserve, Ward 1599. Ngotshe: Ngome Bush, Gerstner 2591 (NH, BOL). Ingwavuma: Cecil Mack's Pass, about $8 \mathrm{~m}$. N. of Ingwavuma, Acocks 13129 (PRE); Codd 2074 (PRE). Without precise locality: "Zululand", Gerstner 2820 (BOL). 
Transvaal.-Nelspruit: Kruger National Park, Crocodile River Poort, van der Schijff 3960 (PRE).

2. A. dispar (N.E. Br.) A. Meeuse, comb. nov.

Mimusops dispar N.E. Br. in Kew Bull. 1895: 107; Engl., Mon. Sapot. Afr. 71 (1904): Wright in Dyer, Fl. Cap. 4, 1: 443 (1906); type: Thresh in herb. Wood No. 5425 from Natal, K, lecto., GRA, NH, isos.!

A large shrub or small tree, up to about $10 \mathrm{~m}$. high. Branches light grey, terete, usually rather rough and the younger ones marked in stretches with the scars of fallen leaves of a previous generation, but these stretches are not so sharply defined as in A. sylvestris (see No. 3); ultimate branches short to very short (unbranched twigs usually less than $10 \mathrm{~cm}$. and of ten less than $5 \mathrm{~cm}$. long). Innovations fulvo-sericeous, but leaves, petioles and twigs soon glabrescent. Leaves oblanceolate-cuneate, or oblanceolate-obovate to obovate-oblong, firm but not coriaceous, rather dull and drying green or yellowish-green above, paler and duller beneath, 2-6 $(-7) \mathrm{cm}$. long and $0 \cdot 75-2$ $(-2 \cdot 5) \mathrm{cm}$. wide, on a $3-8(-10) \mathrm{mm}$. long, subterete, widely canaliculate petiole; blade with a very slightly reflexed margin, obtuse, subacute or shortly and bluntly acuminate, but not usually rounded at the top, gradually narrowing into the acute or acuminatedecurrent base; midrib hardly prominent above, rather prominent below; secondary nerves $6-9$ on either side, not very distinct from the tertiary ones, ascending at an angle of $45^{\circ}-60^{\circ}$, rather straight, bifurcate or branched well within the margin and more or less irregularly archingly joining; tertiary nerves mainly parallel to the secondary ones, but branching and anastomosing to form a rather coarse reticulum which is filled up by a very fine areolate nervation, the latter conspicuous on both sides of the leaf. Flowers few to many (over 20) on one twig, bracts minute; pedicels rather slender, more or less angular, especially in the slightly thickened part under the calyx, 9-16 mm. long, buffy-brown tomentose. Sepals $3-3$ or $4+4$; the outer ones ovate-triangular, acute, or subacute, buffy-brown-tomentose outside, with a whitish margin, greyishtomentose inside near the tip, 5-6 $\mathrm{mm}$. long and about $3 \mathrm{~mm}$. wide; the inner ones about as long and as wide as the outer ones, thinner in texture, ovate-oblong, more obtuse, greyish-pubescent outside with a slightly darker longitudinal streak in the middle and inside at least in the upper half. Corolla yellowish, glabrous; the tube very short, about $0.5 \mathrm{~mm}$. long; the lobes and lateral appendages subequal, linearlanceolate, acute, or subobtuse, 5-6 mm. long and 1-1.5 mm. wide. Stamens 6 or 8; filaments $1 \cdot 5-2 \mathrm{~mm}$. long. subulate from a broad flattened base, the apical part capillary; anthers ovate-lanceolate, acute, $2-3 \mathrm{~mm}$. long, minutely apiculate. Staminodes ovatelanceolate, long-acuminate, concave, hairy at the back, about $3 \mathrm{~mm}$. long. Ovary subglobose, densely villous, about $2 \mathrm{~mm}$. in diameter; style glabrous. rather short and comparatively thick, terete, subulate-columnar, 2-3 $\mathrm{mm}$. long, the apex subacute.

FIG. 9.-Austromimusops marginata, seed and fruit (from Pegler 692, Kentani, E. Cape, in BOL).

Fig. 10.-Austromimusops dispar, seed and fruit (from Pentz et al. " 1 A", Weenen Veld Reserve, Natal).

FIG. 11.-Austromimusops sylvestris: (a) immature fruit (to show the dense pubescence; from Chase 4328, Umtali, S. Rh.) (b) mature seed and fruit (from seeds sent by Mr. N. C. Chase, coll. in Waranki Reserve, Umtali, S.R.)

$N . B$. - The seed figured was from a large 2 -seeded fruit; as a rule the seeds are shorter and comparatively thicker. 


$$
\begin{aligned}
& 000 \\
& 0.04 \\
& 0.0 .9 \\
& 0.9
\end{aligned}
$$


Fruit green or yellowish-green, ellipsoid or ovoid, apiculate, more or less densely covered with a short brown pubescence, $2-3 \mathrm{~cm}$. long, 1.5-2 $(-2 \cdot 5) \mathrm{cm}$. in diam.; pericarp thin, almost leathery when fresh, 1- or rarely 2 -seeded. Seed pale brown, $2-2 \cdot 5 \mathrm{~cm}$. long and $1 \cdot 5-2 \mathrm{~cm}$. in diam. with pale whitish scar.

NATAL.-_" Thorns" nr. Greytown, Thresh in herb. Wood $5425=$ NH No. 7175 (NH, GRA, isos!). Estcourt: Mooi Rivier, "Thorns", Wood 4472 (NH); Sim 2187 , 2188 (NU). "Upper Tugela River:" Gerrard (and McKen) 1482 (NH). Weenen: Weenen Veld Reserve, Acocks 10148 (PRE, NH), Pentz \& Acocks=Acocks 10721 (PRE, NH), Pentz 116, 596; " 1 " (Coll. in 1952), "2" (coll. in 1952). " IA" and "1B" (coll. in 1953 from same trees as " 1 " and " 2 " respectively); all in PRE, the last three fruiting specimens); West 1189, 1190 (PRE); Muden, Sim 19078, 19138 (PRE), Verdoorn 1727 (PRE). Msinga: Confluence of Mooi and Tugela Rivers, Ngobevu, Edwards 881 (NU. PRE). Umvoti: Keats Drift, Edwards 916 (NU, PRE).

3. A. sylvestris (S. Moore) A. Meeuse, comb. nov.

Mimusops sylvestris S. Moore in J. Linn. Soc. (Bot.) 40: 132 (1911); type: Swynnerton 570 from Southern Rhodesia in BM, holo.

A shrub or small tree, up to about $7 \mathrm{~m}$. high, with smooth bole. Branches terete, greyish, with longitudinal shallow grooves and with slightly thicker stretches marked with rough transverse leaf-scars, especially towards the tips of the twigs below the leaves; ultimate branches rather short $(5-15 \mathrm{~cm}$. long) and rather stout (more than $2 \mathrm{~mm}$. thick, sometimes much thicker and up to $6 \mathrm{~mm}$. in diam.), usually with a thicker scarred area just below the leaves. Buds, young leaves and young twigs, pedicels and hracts densely rusty-tomentose. Leaves obovate or obovate-oblong, sometimes oblong or oblong-cuneate, $2 \cdot 5-6(-7 \cdot 5) \mathrm{cm}$. long and $1 \cdot 5-3 \cdot 5(-4 \cdot 5) \mathrm{cm}$. wide, on a rather stout, terete, rather widely canaliculate, rusty-pubescent but ultimately glabrescent, 2-6 $\mathrm{mm}$. long petiole; blade with revolute margin, an obtuse, rounded, emarginate, or more or less retuse, rarely very shortly and bluntly acuminate apex and a narrowed, usually acute but sometimes rounded base, rather firm but not coriaceous in texture, ultimately glabrous and green but not smooth or shiny above, glabrescent but not soon quite glabrous, paler and duller below, midrib usually keeled, sometimes immersed above, rather prominent beneath and keeping vestiges of the original rusty pubescence for a long time; secondary nerves (5-) 7-10 (-12) on either side, as a rule very distinct below, immersed above, rather straight, making an angle of about $60^{\circ}$ with the midrib, usually bifurcate well within the margin and more or irregularly joining, but mostly with one distinct ascending branch; tertiary nerves mainly parallel to the secondary ones, but usually sinuous, branched or more or less reticulate; ultimate reticulate nervation very fine, areolate, in dried leaves usually conspicuous on both sides. Flowers 1-3 together; bracts densely rusty-tomentose, ovate, $2 \mathrm{~mm}$. long, deciduous; pedicels usually $1 \cdot 5-2 \mathrm{~cm}$. long, rather stout, terete, but gradually widening near the apex into the calyx, usually pendulous; in fruit not lengthened but slightly incrassate. Sepals $4+4$ or $5+5$; the outer ones ovate-lanceolate to oblong-lanceolate, about $7 \mathrm{~mm}$. long and $3-3.5 \mathrm{~mm}$. wide, acuminate or narrowed towards the subobtuse apex, densely rusty-tomentose with a distinct greyish-tomentose margin outside, greyish-tomentose inside at least in the upper half; the inner ones somewhat shorter and narrower, greyish pubescent outside with a darker longitudinal streak and inside at least in the upper half. Corolla glabrous; the tube about $1 \mathrm{~mm}$. long; the lobes about $7 \mathrm{~mm}$. long, oblonglanceolate; the appendages slightly shorter. Filaments more or less flattened, rather slender, $1.5 \mathrm{~mm}$. long; anthers oblong, obtuse, apiculate, $3 \mathrm{~mm}$. long. Staminodes long-triangular-lanceolate, concave, with acuminate, dissected, 2-3 fid or somewhat fimbriate apex, villous with long sinuous hairs outside, the upper half strongly inflexed. Ovary sub-globose, about $2 \mathrm{~mm}$. in diam, densely villous; style glabrous, 6-7 mm. long, terete, tapering towards the apex, somewhat truncate-capitate at the tip. Fruit 
ovoid-ellipsoid, attenuate-apiculate, $3-4 \cdot 5 \mathrm{~cm}$. long and $2-3 \mathrm{~cm}$. in diam.. when young densely rusty-tomentose. glabrescent and dull brown when mature, 1-seeded or 2-seeded; pericarp not juicy, rather dry and leathery. Seed broadly ellipsoid to subglobose (those of 2-seeded fruits ellipsoid, more slender), 20-32 mm. long, $=20 \mathrm{~mm}$. in diam.; testa dull, very pale straw-coloured; the scar duller and somewhat lighter in colour (see Fig. 13).

S. Rhodesia.-Umtali: Dora Farm, Chase 964, 965, 966, 774 (SRGH, Chase 965 also in PRE); Glenshiel Farm, Chase 1670 (SRGH); Zimunya Reserve, Chase 4238 (SRGH, PRE); Maranki Reserve: Chase s.n. (ripe fruits, PRE). Bikita: Wild 4393 (PRE, SRGH).

Mr. B. de Winter compared the type, Sirynnerton 570, with Chase 966 (Kew) and informed me that there are some minor differences such as shorter and more hairy petioles, smaller fowers, wrinkled leaves. However, the material I have seen is rather variable and the differences mentioned by $\mathrm{Mr}$. de Winter are well within the range of variation, so that I have no doubt about the specific identity.

Apart from the three species dealt with, there is at least one species in tropical Africa. This species, described as Mimusops cuneata Engl., has several characteristics of an Austromimusops : leaves congested at the ends of the branchlets, with their largest width above the middle, axillary flowers on pendulous pedicels and laterally attached ovules. Judging by Engler's figure and a specimen named Mimusops cuneala (Drummond \& Hemsley 4203 from Kenya, Kwale Distr.. EA, K, PRE) this is very close to Austromimusops dispar (but it is much more glabrous than the latter) and to A. marginata. and although the fruits are apparently still unknown, I do not hesitate to refer it to the same genus:

Austromimusops cuneata (Engl.) A. Meeuse. comb. nov.

Mimusops cuneata Engl., Pflanzenw. O. Afr., C, 307 (1895), and Mon. Sapot. Afr. 70, t. 23, C (1904); Brenan and Greenway, Checklist Tang. Terr. 2: 565 (1949). Recorded from Tanganyika (West-Usambara) by Engler; also in Kenya.

\section{MIMUSOPS}

L., Gen. Pl. ed. 5: 175 (1754), p.p.; Harvey, Gen. S. Afr. Pl. 224 (1838), A. DC. in DC., Prodr. 8: 202 (1844), p.p.; Bentham et Hook.. Gen. Pl. 2: 661 (1876), p.p.; Baker in Oliv., Fl. Trop. Afr. 3: 505 (1877), p.p.: Hartog in J. Bot. 17: 358 (1879), p.p.; Engler in Engl. \& Prantl., Naturl. Pflanzenfam., ed. 1, 2, 4: 150 (1899), and in Nachträge (1897) 278, pro parte; Engl., Mon Sapot. Afr. 50 (1904), p.p.; Pilger in Engl. \& Prantl, Nachträge 1897-1904, 288 (1906) p.p.; Wright in Dyer, Fl. Cap. 4, 1: 439 (1906), p.p.; Dubard in Ann. Mus. Col. Marseille 23: 46 (1915), Baehni in Candollea 7: 465 (1938); Lam in Blumea 4: 345-347 (1941); Phillips, Gen. S. Afr. Fl. Pl. ed. 2, 568 (1951), p.p.; Royen in Blumea 6: 594 (1952).

Type species: Mimusops elengi L., Sp. Pl. ed. 1: 349 (1953). Linnaeus mentioned two species, M. elengi and M. kauki. Mimusops kauki L. is now generally assumed to be the type species of Manilkara Adans. [see discussion by Van Royen in Blumea 7: 406 (1953)], which makes $M$. elengi L. undoubtedly the type species of Mimusops L. apart from priority of place.

Trees or shrubs. Leaves extipulate, not conspicuously crowded towards the tips of the branches and without sclereids and with a rather lax, not conspicuously parallel or "striate" secondary nervation. Flowers axillary, pedicellate, constantly 4-merous., Calyx biseriate $(4+4)$; the sepals free nearly to the base, often long and narrow. 
Corolla 8-lobed, each lobe with 2 dorsal appendages; the latter entire or divided (in S. Africa always entire). Stamens 8 , inserted in the throat of the corolla tube; the anthers usually (in S. Africa always) shorter than the long, more or less lanceolats and apiculate anthers. Alternipetalous staminodes 8, entire, or somewhat dentate, lacerate or fimbriate at the apex only, often pubescent at least at the back or along the edges (in S. Africa never glabrous), incurved, and more or less covering the style. Ovary 8-loculated; ovules with basal attachment; style rather long and slender, cylindricsubulate to filiform. Fruit a 1- to few-seeded berry. Seeds with a small, circular and almost basal scar; testa shiny hard and thick; endosperm copious, cotyledons thin, foliaceous.

The genus Mimusops as understood by Bentham and Hooker, Hartog, Engler and several others is most heterogeneous and comprises forms with 3-merous and others with 4-merous flowers, species with long and narrow ventral seed-scar and others with circular basal scar, plants with staminodes and others without staminodes, forms with endosperm and others without endosperm, etc. Dubard (1915) excluded many species and referred them to several other genera, the majority to Manilkara Adans. The latter genus is now almost universally adopted, cf. Van Royen in Blumea 7: 401 (1953), but is should be borne in mind that the large genus Mimusops sensu Hartog and Engler does not become more homogeneous if only Manilkara is taken out. If, however, Muriea, Austromimusops, Baillonella, Lecomtedoxa and perhaps several other smaller genera are also exluded, the remainder of Mimusops is a reasonably well defined homogeneous genus. In its limited sense, Mimusops L. sensu Dubard, Lam and Van Royen comprises between 30 and 40 species, all occuring in Africa, Madagascar, and the Mascarenes, with the exception of $M$. elengi L., a coastal form which occurs in tropical Asia and the W. Pacific. Three species in Southern Africa:

Leaves obovate, obovate-cuneate or almost obcordate, always distinctly narrowing towards the base, usually emarginate or retuse, with strongly revolute edges and at least when young, with white sometimes fulvous adpressed, more or less silky pubescence below (very old leaves glabrous). Coastal tree.......................... 1. M. caffira.

Leaves different, glabrous when old or with " powdery " vestiges of a rusty brown pubescence:

Petioles under $1 \mathrm{~cm}$. long: leaves usually rather small (mostly under $6 \mathrm{~cm}$. long) and usually drying dark brown; branches and leaves very soon glabrous; flowers about $2 \mathrm{~cm}$. in diameter when fully expanded, very rarely smaller, usually solitary in the axles, sometimes 2 together, usually not numerous on a single branch-

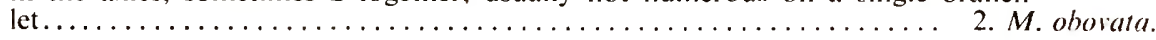

Petioles over $1 \mathrm{~cm}$. long; leaves of ten over $6 \mathrm{~cm}$. long, innovations and young leaves, as well as tips of young branches densely rusty-pubescent, the tips of the branches often remaining pubescent for a considerable time, flowers up to $1.5 \mathrm{~cm}$. in diam, when fully expanded, often in clusters of more than 2 flowers, often numerous on a single branchlet............................ 3. zeyheri.

1. M. caffra E. Mey. ex A. DC., Prodr. 8: 203 (March 1844); Wood, Natal P1. 1: 36, t. 43 (1898); Engl., Mon. Sapot. Afr. 72, t. 27, Fig. B (1904); Wright in Dyer, Fl. Cap. 4, 1: 441 (1906), Sim, For. Fl. Cape Col. 255, fol. 97 (1907); and For. Fl. Port. E. Afr. 80, pl. 75 (1909); Gerstner in J. S. Afr. Bot. 12: 52, Fig. 7 (1946). M. caffra E. Mey. ex Drege, Zwei Pflanzeng. Doc. 155 (1843), nomen tantum; type: Drege s.n. from Pondoland in G ex herb. DC, holo, L, iso! M. revoluta Hochst. apud Krauss in Flora 27: 825 (Dec. 1844); type: Krauss 76 from Durban in ?, holo, $\mathrm{K}$ iso .

A small tree or large shrub, forming a large propertion of the vegetation on the sand dunes, growing down to the high-water mark and fully exposed to sea winds and spray; exposed specimens usually dwarfed and gnarled, but in sheltered places growing up to about $10 \mathrm{~m}$. high and over $50 \mathrm{~cm}$. stem diameter. Branches terete, usually rather stout (about $3 \mathrm{~mm}$. thick), densely leafy towards the tips. Innovations densely rustytomentose. Leaves obovate, obovate-oblong or obovate-cuneate to almost obcordate, 
3-6 (-7) $\mathrm{cm}$. long and 1 $\cdot 5-3(-4) \mathrm{cm}$. wide; blade firmly coriaceous usually with strongly reflexed margin, glaucous and glabrous above, paler and adpressed silky-pubescent beneath (almost invariably white or silvery), with usually rounded emarginate to retuse apex, tapering into the 5-10 $(-15) \mathrm{mm}$. long petiole; midrib usually a little prominent above in the lower half of the leaf, or flush, rarely somewhat immersed, prominent beneath at least in the lower half; secondary nerves almost straight, slightly prominent on both sides, forming an angle of $30^{\circ}-50^{\circ}$ with the midrib, joining a conspicuous, sinuous intramarginal vein; tertiary nerves and finer nervation hardly more slender than the secondary nerves, and mainly parallel to the latter. Petioles terete. slightly thickened towards the base, narrowly but rather deeply channelled above, ultimately glabrous, 5-10 $(-15) \mathrm{mm}$. long. Flowers usually numerous on one branchlet, often 2-4 together in the leaf axils. Pedicels usually recurved, $2-3 \mathrm{~cm}$. long, mostly distinctly 4-angled, shortly rusty-tomentose (this pubescence tending to become grey later), more or less gradually widening into the calyx. Flower-buds about $12 \mathrm{~mm}$. long just before opening. Sepals lanceolate, acuminate, about $1 \mathrm{~cm}$. long; the outer ones rustytomentose outside, about $3 \mathrm{~mm}$. wide, the inner ones with pale tomentum, about 2 $\mathrm{mm}$. wide. Corolla about as long as the calyx, glabrous; the tube short, the lobes about $10 \mathrm{~mm}$. long, each with two about $7 \mathrm{~mm}$. long appendages, all segments lanceolate. usually in two rows consisting of an outer row of 16 appendages and an inner row of 8 corolla lobes. Filaments about $2.5 \mathrm{~mm}$. long; anthers about $6 \mathrm{~mm}$. with acute apiculum. Staminodes triangular-ovate, slightly longer than the filaments, densely pilose outside with long hairs. Ovary ovoid. densely pilose, about $2 \mathrm{~mm}$. long; style long-cylindrical, tapering into an acute point, about $11 \mathrm{~mm}$. long. Fruit ovoid, $1 \cdot 5-2$ $\mathrm{cm}$. long, $1-1 \cdot 5 \mathrm{~cm}$. diam.. more or less rounded at the top but often contracted into and crowned by the persistent style, red when ripe, edible, usually (always?) 1-seeded; fruiting pedicels hardly lengthened, slightly incrassate. up to $3 \mathrm{~cm}$. long and about $2 \mathrm{~mm}$. thick; calyx-lobes persistent under fruit, adpressed to the fruit, greyish pubescent. Seed oval, subcompressed, indistinctly keeled at the ventral side, not produced at the base, 13-17 mm. long, 8-9 mm. wide and 5-7 mm. thick in the middle; testa shining brown.

\section{Selected Citations.}

Cape Province.-Bathurst: Kowie and Port Alfred, Burchell 3805; Britten 2107, Marloth 18097; Burt-Davy 7856: Tyson s.n.: Story 2163. East London: Galpin 1835, 9285; Smith 3817. Komgha: Kei Mouth, West 2024. Kentani: Pegler 1298. Elliotdale: O. B. Miller FD herb. No. 5591 (SAFD). Port St. Johns: Schönland 4038, Mogg 770 ( = photo of tree, PRE); Howlet 44.

Cape Province or Natal.-Bizana or Port Shepstone: "between Umtentu and Umsamkulu ", Drege (L. isotype).

Natal._Port Shepstone: Margate, Bayer 1305 (NU); Port Shepstone, Mogg 13197. Umzinto: "South Coast, nr. Botha House ", Smuts 2325; Sezela, Smuts s.n. Pine Town: Winkle Spruit, Rudatis 1608; Amanzimtoti, Kotzé 453. Durban: near Durban, Forbes \& Obermeyer 72. Lower Tugela: Stanger, Pentz 386. Mtunzini: Inyoni bush, Gerstner 1936. Hlabisa: St. Lucia Bay, Lansdell $31(\mathrm{NH})$. Ubombo: near Sordwana Bay, Gerstner 733; Ward 3013.

Portuguese E. Africa.-Sul do Save: Lourenço Marques, Schlechter 11986; Rogers 21374; Junod 134; Borle 30; Pedro 59; Gomes e Sousa 3770; Maputo, Hornby 2619; Inhaka Island, Mogg s.n.; Chongoene, Pedro \& Pedrogão 1645. Manica e Sofala: Inhambane, Earthy 172 (PRE); Gomes e Sousa 1701, 1739, 1908 (COI).

As regards the synonymy, Mimusops caffra was the only name used for this species in all recent publications, but Krauss in 1844 validly published Mimusops revoluta Hochst., based on Krauss 76 from Durban. Strangely enough, this name was not 
mentioned by Engler (op. cit.) as a synonymn of $M$. caffra and is not cited in Fl. Cap., although the number Krauss 76 is quoted in the latter publication. Mr. de Winter kindly supplied the information that an isotype is present in the Kew herbarium and that it is identical with $M$. caffra. Fortunately, the publication of $M$. caffra E. Mey ex A. DC. antedates that of $M$. revoluta Hochst. apud Krauss by several months (mid March 1844 against December 1844) so that the well-known and generally used name $M$. caffra need not be changed.

M. caffra is found on coastal sand dunes from Port Alfred (Bathurst) eastwards and northwards to Portuguese E. Africa, also here and there along large rivers more inland on sandy soil.

2. Mimusops obovata Sond. in Linnaea 23: 17 (1850); Harvey, Thes. Cap. 1: 28. t. 44 (1859); Engler, Mon. Sapot. Afr. 72, t. 27, Fig. D (1904); Sim, For. Fl. Cape Col. 254, pl. 96 (1907); Wright in Dyer, Fl. Cap. 4. 1: 442 (1906); Marloth, Fl. S. Afr. 3: 36, t. 10 (1932); Gerstner in J. S. Afr. Bot. 12: 54, Fig. 10 (1946); type: Ecklon \& Zeyher "Sideroxylon No. 16" from Alexandria, lecto! in S, isos! in GRA, PRE.

Imbricaria obovata N. ab. E. ms. ex Sonder, 1.c. in syn., Engler, op. cit., 72, in syn. Mimusops oleifolia N.E. Br. in Kew Bull. 1895: 109 Engler, op. cit., 73, t. 34, Fig. B; Wright, op. cit., 442; type: Gerrard 1642 in K, holo., NH, iso! from " Tugela ", Natal.

M. woodii Engl., op. cit., p. 65, t. 26, Fig. A; Wright, op. p. 440; type: Wood 683 in $\mathrm{B}$, holo†, BOL, NBG, isos! from Inanda, near Durban.

M. rudatisii Engl. et Krause in Engl. Bot. Jb. 49 (1913), p. 395; type: Rudatis 1136 in B, holo†, L, PRE, isos! from Dumisa, Natal.

A medium-sized tree, up to $20 \mathrm{~m}$. high and $60 \mathrm{~cm}$. stem diam., according to Sim (in MS.) occuring mainly in rather open mountain forests, but also in coastal areas. Branchlets terete, glabrous, rather slender, usually longitudinally wrinkled and light grey, as a rule uniformly leafy. Innovations rusty-tomentose, very soon glabrescent. older parts ultimately quite glabrous. Leaves variable in size and shape, but usually obovate, obovate-oblong or obovate-cuneate, sometimes more oval or elliptic or obovate-oblanceolate, $2-6(-7) \mathrm{cm}$. long and $\mathrm{l}-3(-4) \mathrm{cm}$. wide, rarely narrowly lanceolate, 2.5-6 cm. long and 4-9 mm. wide, more or less thinly coriaceous, usually drying very dark brown and shiny above, pale brown and dull beneath, sometimes drying grey above; the apex obtuse or rarely subacute, sometimes rounded, but mainly in the obovate-cuneate type of leaf) not infrequently with a short, blunt acumen, tapering at the base, which is always acute or subacute, and with minutely reflexed margins; midrib almost flush above, slightly prominent beneath; secondary nerves ascending at an angle of $\pm 45^{\circ}$, rather straight, but very few reaching the leaf margin without brancing, joining other veins or slightly deflexing in the points where the tertiary nervations join them, archingly joining near the margin; tertiary veins forming a rather fine distinct reticular nervation which is usually very conspicuous in dried leaves and slightly prominent, at least on the lower surface. Petioles comparatively slender, terete, channelled above near the leafbase, 3-9 mm. long. Flowers white, fragrant, solitary or in twos in the leaf axils on 1-3 (usually $1 \cdot 5-2) \mathrm{cm}$. long, brownish-tomentose, slender and suberect or patent, usually not distinctly drooping pedicels; flower buds usually $\pm 1 \mathrm{~cm}$. long just before opening. Outer sepals (6-) 8-12 mm. long and 3-3.5 mm. wide, shortly rusty-tomentose with a very narrow whitish or pale-grey edge, narrowly ovate-lanceolate, acuminate; inner sepals slightly shorter and narrower, with a pale grey or whitish tomentum and minutely ciliate, soon reflexed. Corolla-tube short, $1 \mathrm{~mm}$. long; the 8 lobes linear-lanceolate or 
narrowly oblong, $\pm 1 \mathrm{~cm}$. long, rarely smaller $(6-8) \mathrm{mm}$., the lateral appendages about as long, usually more acute than the lobes. Filaments thick, 1-2.5 mm. long, much shorter than the sagitate-oblong, or linear oblong, apiculate, 3-6 mm. long anthers. Staminodes long-triangular or lanceolate-subulate from a broad base. villous outside, shorter than the stamens but longer than the filaments. Ovary ovoid or oblong-ovoid, $\pm 2 \mathrm{~mm}$. high, densely pilose; style glabrous, terete, slender, longer than the corolla and up to $-12 \mathrm{~mm}$. long, slightly tapering towards the apex which is truncate and often subcapitellate. Fruiting pedicels somewhat incrassate; calyx under fruit persistent, reflexed or ultimately deciduous. Fruit ovoid or ovoid-acuminate, $2-3.5 \mathrm{~cm}$. long, 1-2 cm. in diam., often 1-seeded, ultimately glabrous, smooth, orange-red or yellow when ripe. Seed, when single, $2-2 \cdot 5 \mathrm{~cm}$. long, $8-10$ wide and $6-8 \mathrm{~mm}$. thick in the centre, oblong. with rounded apex and obliquely truncate-notched base. often distinctly keeled on the side above the small, circular, $t 2 \mathrm{~mm}$. wide scar, but if more seeds are present in one fruit, often smaller and ti irregularly shaped, flattened and less distinctly truncate-notched or keeled; testa brown, shiny.

General Distribution.-From the Eastern Cape eastward and northwards into Natal, Swaziland, Zululand, Eastern Transvaal and Portuguese East Africa (possibly extending into tropical East Africa, because several species described from that area appear very similar from the descriptions, but no actual specimens seen) in evergreen forests in frost-free areas, mainly at low to fairly low altitudes.

CaPe Province.-Alexandria: Olifantshoek, Ecklon \& Zeyher (S, lecto., PRE, GRA isos); Zeyher (PRE), Ecklon \& Zeyher or Zeyher (SAM). Bathurst: Acocks 11139 (PRE); Kariega Mouth, Acocks 18348 (PRE); Port Alfred, Britten 1681 (GRA. PRE). Albany: near Grahamstown, MacOwan 258 (GRA. HN, BOL. SAM): Galpin 179 (GRA, PRE): Beggar`s Bush Forest Reserve, Archibald 5966 (PRE); Blaauwkrantz, Britten 897 (GRA, PRE); Paradise Kloof. Story 3128 (PRE). Stutterheim: Sim 2273 (or 21922?; NU); Acocks 8939; Story 1242. King William's Town: Pirie, Sim 1333 (NU); Ross s.n. (SAFD No. 1903). East London: Galpin 3164 (GRA, PRE), 9518. 10432 (PRE); Simith 3783, 3818 (PRE): Sim 2189 pp. (NU). Komgha: Flanagan 249 (PRE, BOL, SAM). Kentani: Pegler 765 (PRE. BOL, GRA. NBG); Qolora, Edward in h. Moss 17544 (J). Engcobo: Manina, Zahn 22, v.d. Merwe FD No. 2200 (SAFD). Ngqeleni: Qokama, Acocks 13426 (PRE). Port St. Johns: near Port St. Johns, Moss 4686 (J); Boshoff FD No. 5032 (SAFD). "Pondoland": Egossa and Port St. Johns, Sim 2418 (NU, PRE). Lusikisiki: Acocks 13426 (PRE), Miller FD No. 5771 (SAFD). Flagstaff: $R$. C. Coloured School s.n. (GRA).

Natal.-Port Shepstone: "South Coast Natal". Pole Evans 761 (PRE); Southbroom, Codd 9705 (PRE). Umzinto: Dumisa, Rudatis 1136 (L, PRE, isos of $M$. rudatisii Engl. et Krause). Umlazi: Park Rhynie, "Indian collector" s.n. (NH No. 14819); Winkle Spruit, Van der Bijl s.n. (NH No. 16136). Durban: Isipingo, Ward 342 (NU), 503 (NU. PRE); near Durban, Wood 5797 (BOL), 9112 (PRE); Gerrard \& McKen 720, 869 (NH); Rogers 24502 (PRE); Stayner 20 (BOL); Wylie s.n. $(=23114$, also PRE); Inanda, Wood 683 (BOL, NBG, isos of $M$. woodii Engl.); Umgeni Dam, Bayer 1387 (NU, NH, PRE, BOL). Pine Town: Marian Hill, Forbes 1039 (NH). Verulam: Umhloti Beach, Codd 1499 (PRE). Kranskop: Jameson's Drift, Bayer 540 (NU). Msinga: Nogbeva, Edwards 878 (PRE, NU). Nkandla: Middeldrift, Edwards 1423. 1424 (PRE, NU). Eshowe: Lawn 666 (NH); Gerstner 1922 (PRE), 2262, 2440 (NH. PRE), 2819 (BOL), 2994 (NH); Entumeni Waterfall, Wylie s.n. p.p. (NH No. 12940, the remainder is $M$. caffra). "Tugela": Gerrard $1642(=$ iso. of oleifolia N. E. Br., NH). Mtunzini: near Mandeni, Edwards 1616 (PRE, NU). Lower Umfolozi; Umfolozi Game Reserve, Ward 3159 (PRE); Kluge 19 (NH); Mtonjaneni: Gerstner 3675 (NH, PRE); Empangeni, Gerstner 2767 (NH), 2730 (NH, BOL, PRE). Hlabisa: Hluhluwe, Ward 1700 (PRE); Masimba Hill, West 2078 (NH, PRE); Hlabisa 


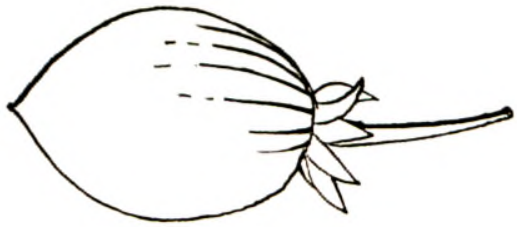

导
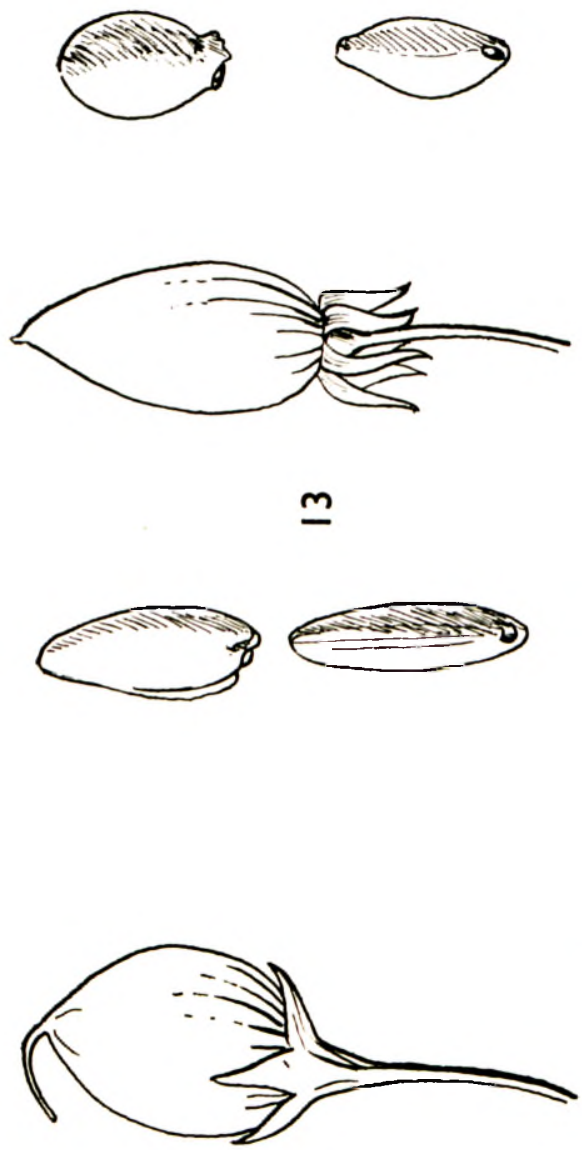

工
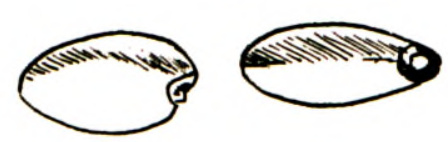
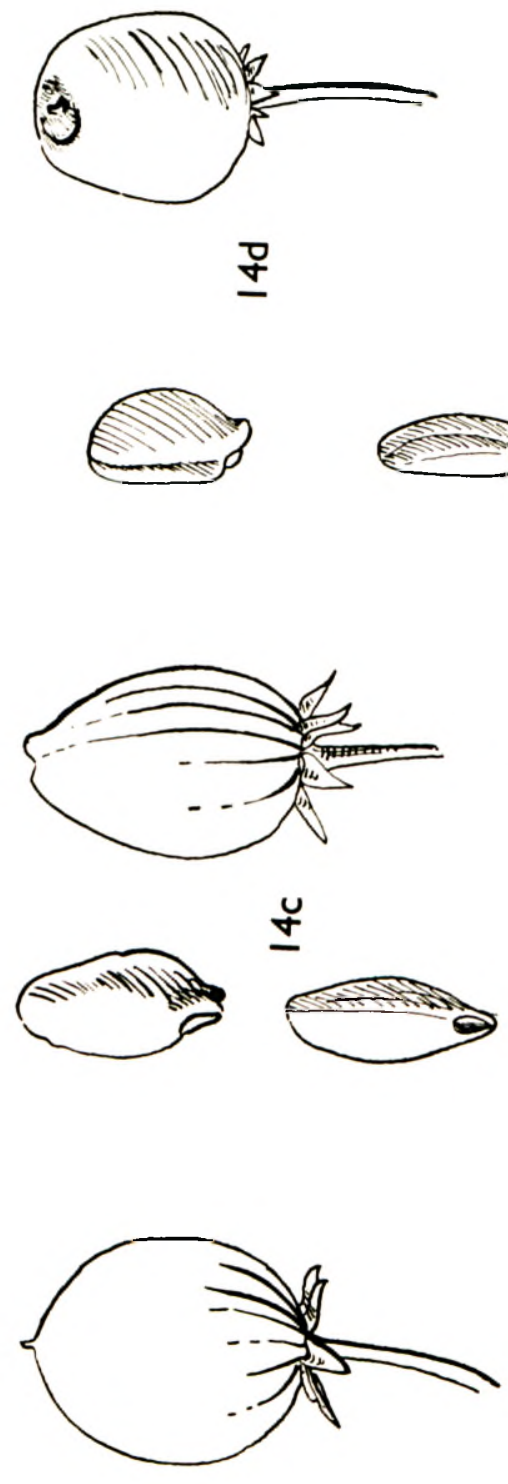

ำ

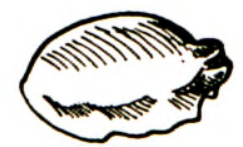

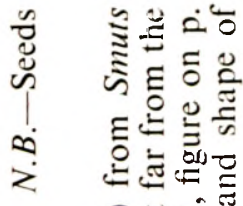

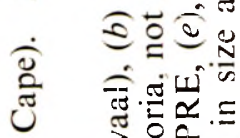

山 ڤัँ $\cong$.

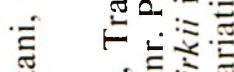
oi $= \pm$

ป辶่ 记豆

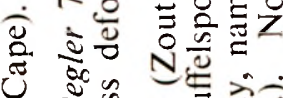
U क्ष थै ल

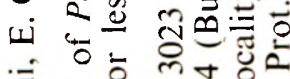
ఏ. ప

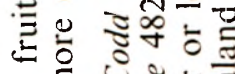
른ㅎำ 寸 $\stackrel{1}{\approx} \frac{\bar{\sigma}}{\sigma} \infty$

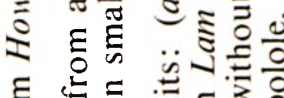
을.

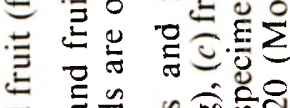

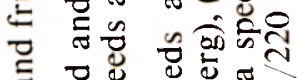
స

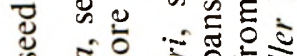
i ป ป ะ

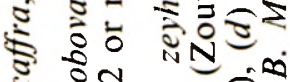

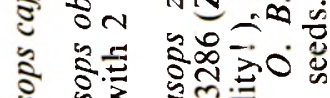

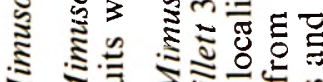

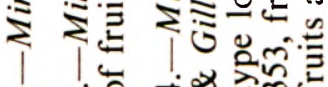
i 这 
or Umbombo: near northern end of St. Lucia Lake, Gerstner 4987 (PRE). Nongoma: Wendelane Kloof, Gerstner 4659 (PRE, NBG). Ngwavuma: Bayer 760 (PRE). Natal without precise locality: Gueinzuis (original syntype gathering, presumably from the vicinity of Durban, in SAM); Cooper 1241 (BOL, NH, PRE).

SwazILAND.-Steliart s.n. (TRV No. 8824 in GRA, PRE); Ubombo Mts. near Stegi, Keith S.n. (PRE).

TransvaAl. - Sebasa: Phephidi River (prob. near Phephidi Falls), Legat 1 (SAFD). Letaba: Patatabos, Botha s.n. = FD. No. 7154 (SAFD, PRE); The Downs, Renny. DB 52 (PRE); De Hoek, Keet FD No. 7413 (SAFD).

Portuguese EASt Africa.-Sul do Save: Lourenço Marques, Gomes e Sousa 3859 (COI, PRE).

N.B.-The specimen mentioned in Fl. Cap. 4, 1: 442 from Warmbaths, Transvaal (Burtt Davy 2625) is not M. obovata Sond., but M. zeyheri Sond.

The shape of the leaves of one specimen is usually fairly uniform but the various forms described as $M$. oleifolia N.E. Br., M. woodii Engl. and $M$.rudatisii Engl. \& Krause, are, in my opinion, only ecotypes, as was already suggested by Gerstner. The forest form has rather thin leaves which are large and obovate, and corresponds with the descriptions of $M$. obovata and of $M$. woodii; a depauperate form growing in rocky places in the sun, has small coriaceous leaves, flowers more freely and corresponds with the narrow-leaved $\boldsymbol{M}$. oleifolia. Not only are all these forms linked up in the herbarium by intermediate specimens, but the flowers, branches, pedicels, fruits and seeds are also identical.

A type specimen was not defined, because Sonder mentions the numbers Gueinzius 583 and 101 ex parte from Durban, and Ecklon \& Zeyher"s "Sideroxylon No. 16" from Olifantshoek. The Ecklon \& Zeyher collection being the best known and better represented in various herbaria, I propose the E. \& Z. specimen in herb. Sonder (S) as the lectotype.

3. M. zeyheri Sond. in Linnaea 23: 44 (1850); Engl., Mon. Sapot. Afr. 73, t. 27, Fig. C (1904), incl. var. laurifolia Engl.; Wright in Dyer, Fl. Cap. 4, I: 441 (1906); Gerstner in J. S. Afr. Bot. 12: 54 (1946); Meeuse in R. A. Dyer. Fl. Pl. Afr. 30: t. 1164 (1954), type: Zeyher 1130 in herb. Sonder, holo., BOL, NBG, isos.! $M$. kirkii Baker in Oliv., Fl. Trop. Afr. 3: 567 (1877); Engl., op. cit. 67; Gerstner, op. cit., 55, type: Kirk s.n. from Lower Shire Valley and Kirk s.n. from Rovuma in K, syns. M. monroi Sp. Moore in J. Bot. 49: 55 (1911); type: Monro 761 in BM, holo; BOL. SRGH, isos!

A tree reaching a height of at least $10-15 \mathrm{~m}$., with spreading branches and a leafy, umbrageous canopy. but often appearing as a large shrub. Innovations densely adpressed rusty-tomentose, the twigs often retaining the pubescence for some time, the leaves sometimes in the form or irregular, powdery patches or along the midrib; branches, petioles and leaves ultimately glabrous. Leaves coriaceous or thinly coriaceous, shiny above, paler beneath, usually drying a pale greyish-green (young ones drying dark brown above, brownish-grey beneath), ovate-lanceolate to oblong-ovovate, sometimes obovate or broadly elliptic, sometimes broadly lanceolate, usually obtusely acuminate or gradually tapering into the obtuse or more rarely slightly emarginate. occasionally rounded apex, tapering, acute or subacute at the base, with slightly thickened and subreflexed margin, 4-9 (-1I) $\mathrm{cm}$. long (on coppice shoots occasionally up to $15 \mathrm{~cm}$. long) and 2-4 (-5) $\mathrm{cm}$. wide, on a (10-) 15-35 $\mathrm{mm}$. long, terete, petiole which is rather firm, narrowly canaliculate at least near the leaf-base and not infrequently shows vestiges of the original reddish-brown tomentum; midrib forming a fine keel above, prominent below, very gradually tapering towards the apex of the leaf; lateral 
nerves ascending at an angle of $45^{\circ}-60^{\circ}$, usually not reaching the margin without branching, joining or deflexing, archingly joining near the edge of the leaf, not or hardly distinct from the tertiary nerves, the latter first more or less parallel to secondary ones, then becoming irregular, forming a rather coarse reticulate meshwork filled up by a finer reticulate nervation; secondary and tertiary nerves usually conspicuous, slightly raised, finer nervation often inconspicuous. Pedicels often numerous on the twigs in fascicles of 3 or more in the leaf axils, sometimes only $1-3$ per axil, $10-30 \mathrm{~mm}$. (but almost invariably between 15 and $25 \mathrm{~mm}$.) long, rusty-pubescent, recurved, not lengthening but slightly incrassate (up to $1.5 \mathrm{~mm}$. thick) in fruit. Flower-buds just before opening 5-7 mm. long and 3-4 mm. thick. Sepals long-triangular to ovate-lanceolate, acute; the outer ones rusty-pubescent often with a narrow pale edge, 5-6 (-7) $\mathrm{mm}$. long and 2-3 mm. wide, the inner ones pale greyish-white tomentose, slightly shorter and narrower. Corolla-lobes about equalling the calyx, about $6 \mathrm{~mm}$. long, linear-lanceolate, acute, their appendages about or long as shorter $(4-6 \mathrm{~mm}$.), linear-lanceolate and acute. Anthers elongate-sagittate, apiculate, about $3.5 \mathrm{~mm}$. long on subulate, $1.5 \mathrm{~mm}$. long filaments. Staminodes long-triangular or triangular-lanceolate, either shorter than the stamens and acute, or longer than the stamens and long-acuminate to nearly aristate, densely pilose outside. Ovary globose or ovoid, about $2.5 \mathrm{~mm}$. long, villous, attenuated into a 5-10 $\mathrm{mm}$. long style, the latter glabrous, terete, longsubulate, tapering towards the apex. Fruiting calyx not accrescent, somewhat spreading but not quite reflexed as a rule. Berry ovoid, ellipsoid or almost spherical, 2-3 cm. long, $1-2 \cdot 5 \mathrm{~cm}$. diam, sometimes smaller, glabrous and yellow when ripe, usually crowned by the persistent style (at least when young), with mealy, edible pulp, 1-4 seeded. Seeds obovate or elliptic, compressed, usually 15-20 mm. long, 9-12 mm. wide and 4-5 mm. thick, sometimes considerably smaller; often (especially when only 1 or 2 seeds are present) more or less laterally produced or at any rate somewhat attenuated at the base; the scar nearly basal, almost horizontal, in a hollow sinus; testa light brown, shiny.

General Distribution.-Bechuanaland, Transvaal, Swaziland, Portuguese East Africa, Rhodesia and extending into tropical East Africa.

Bechuanaland.-Gaberones, Van Son s.n.; Kanye, O. B. Miller B/298; Lobatsi Govt. Farm, O. B. Miller B/245 (PRE); Molepolole, O. B. Miller B/220 (PRE); Chobe Riv. nr. Serondela, O. B. Miller B/337 (PRE).

TransvaAl.-Marico: Louw 610; Zeerust, Thode A1438. Rustenburg: Rustenburg, Sutton 885, 885a, 1023; Phillips s.n.; Phillips \& Schweickerdt 3550; Rose-Innes 1 (PRE); Pretoria, Brits and Magaliesberg Range: Zeyher 1130 (BOL, SAM, isos!); Burke 72 (PRE, SAM, for practical purposes duplicates of Zeyher 1130); Leendertz s.n. 949; Galpin 6975; Lam \& Meeuse 4824 (L); Meeuse 9095, 9095a; Hutchinson \& Mogg 2905. Johannesburg: Modderfontein, Putterill 161. Middelburg: Olifants Riv. Gorge, Mogg 22447. Warmbaths: Warmbaths, Burtt-Davy 2149, 2625; Galpin 8853. Waterberg: Nylstroom, Prosser 1753, Rietspruit, 40 miles NNW of Vaalwater, Simuts 362. Potgietersrust: Galpin 8823, 9023; Smuts 2006, Pietersburg: Blaauwberg, Leipzig, Bremekamp \& Schweickerdt 1118; Daviesville, Setali, Gerstner 5429; Woodbush, Hoffmann 30; De Hoek Forest Reserve, Keet h. No. FD 7413. Zoutpansberg: near Louis Trichardt, Obermeyer, Schweickerdt \& Verdoorn 361a; Hutchinson 2004; Rodin 3987; Rogers 2177; Hanglip, Gerstner 5994; 20 miles NW of Louis Trichardt, Codd 3023; Happy Rest, Gerstner 6031; 10 miles E. of L. Trichardt, Gerstner 5731; Tshakoma, Obermeyer 1092; 10 m. W. of Wyllie's Poort, Gerstner 
5923 (PRE). Sebasa: Phepidi Falls, Simuts \& Gillett 3308, 3286; Curson \& Irvine 55. 109; Legat 4819; Kruger National Park, near Pafuri, 1. d. Schijff 578, 3812; id., Punda Maria, Lang s.n.; Codd 6514; v. d. Schijff \& Marais 3728. Letaba: Duiwelskloof, Gerstner 5881. Lydenburg: Sekukuniland, van Warmelo 94; Mogg 16916 (PRE); Barnard \& Mogg 762; Barnard 13 (PRE). Pilgrims Rest: Mariepskop. Scheffler FD herb. No. 9946 (SAFD); Lothian, FD herb: No. 890 (SAFD). Nelspruit: Kruger National Park, Numbi: van der Schijff 25; 'near Sabin, Codd 4409 van der Schijff 696, 1461 Barberton: Thorncroft 2177; Liebenberg 2630; Burt-Dary 2810 .

Swaziland.-Lebombo Mts., Hornby 2805; Stegi, Codd \& Dyer 2910. O. B. Miller S $76 ;$ Acocks 15350.

Portuguese E. Africa.-Sul do Save: Guija, Myre \& Balsinhas 788 (PRE): Pedrogão 262 (PRE); Pedro \& Pedrogão 2974 (PRE) Chegua, Chongoene. Gomes e Sousa 3999 (PRE); Matola, Imputa River, Mogg s.n. (PRE); Macovane, Hornby 2714 (SRGH, PRE). Manica e Sofala: Serra da Gorongoza, Simāo 952 (PRE); "á milha 25 da T.Z.R.", Simão 818 (PRE); Lifumba (Mutarara), Simão 1488 (LM). Zambezia: Mocuba, Namagoa, Faulkner 56 (PRE, COI); betw. Régulo Ingive and Nante, Barbosa \& Carvalho 4203 (PRE). Niassa: Pto. Amelia, btw. Mocimboa da Praia and Palma, Barbosa 2122 (PRE).

S. Rhodesia.-Bulalima-Mangwe: Plumtree, Davies 280 (SRGH); Mangwe. Marula, Plowes 1309 (SRGH. PRE). Bulawayo: Matopos, O. B. Miller B/1257 (PRE). Mundy 892, 904, 909 (SRGH); Plowes 1331 (SRGH, PRE); West 2941 (SRGH): Orpen 049/50 (SRGH); Borle 45 (PRE); West 2494 (SRGH). Belingue: Harvie 9/51 (SRGH); 9/51 (SRGH); West 2792 (SRGH); Nuanetsi: Matibi I Reserve. Davies 1773 (SRGH, PRE); Ft. Victoria: Eyles (?) in SRGH No. 3863; N.N. $52 / 51$ in SRGH No. 34663; McGregor 2/47 (SRGH); Acheson 13 (SRGH); Monro 690 BOL); 761 (SRGH, BOL isos of Mimusops monroi Sp. Moore); Zimbabwe. Hornby 2831 (PRE); Smuts s.n. (PRE); Gerstner 6987 (PRE); Seward 47/51 (SRGH): Seymour-Hall 3/51 (SRGH) Chilimanzi: Wormold 21/51 (SRGH); Mylne 1/51 (SRGH); Kirkham 18/51 (SRGH); Gibson 5/51 (SRGH); Greenhow 24/51 (SRGH. PRE). Sabi-Lundi: Wild 3353, 3377 (SRGH. PRE). Ndanga: Chase 2338 (SRGH, PRE), 2416 (SRGH). Gwelo: Eyles 5555 (SRGH); leg. Eyles (?) (SRGH No. 3331); Steedman 210 (SRGH). Hartley: Homby 3230 (SRGH); Jack s.n. (SRGH No. 4082); Umniati Riv., Mills 5/47 (SRGH). Umtali: Obermeler 2070 (PRE); Chase 317. 1314, 1531 (SRGH), 869 (SRGH, PRE). "Eastern Border": Chorley s.n. (SRGH No. 3685). Vumba Mts.: Chase 1741 (SRGH). Salisbury: Concession. Eyles? in SRGH No. 1124. Mazoe: Eyles 4773 (SRGH); Mundy s.n. (SRGH No. 2090); Ford s.n. (SRGH No. 5146). Lomagundi: Eyles 2689, 2715 (SRGH. PRE, SAM), 3130 (SAM. PRE) 4971. 4973 (SRGH) Pardy s.n. (SRGH Nos. 5918, 5924). "Zambesi": West 2900 (SRGH). Urungwe: Lovemore 291, 361 (SRGH. PRE). Victoria Falls: Flanagan 3302 (BOL); Galpin 7044 (GRA, PRE, BOL), 14999 (PRE); Rogers 5310 (GRA, BOL. SAM); 7446 (J); Schwartz s.n. (BOL 25012); Rodin 4492 (PRE, SRGH); Wild 3130 (SRGH); Greenway 6250 (PRE), Poynton $12=$ FD herb. No. 10403 (SAFD).

Northern Rhodesia.-Nega-Nega Hills: Burtt Davy 762 (PRE). (PRE).

Nyasaland.-Likubula Gorge: Brass 16366 (= Vernay Nyasaland Exp. 1946) 
As regards the identity of $M$. zeykeri Sond and $M$. kirkii Baker the following " differences" can be found in the original descriptions (see also Engler, op. cit.):

\begin{tabular}{l|l}
\hline & \multicolumn{1}{|c}{ M. zevheri. } \\
\hline $\begin{array}{l}\text { Pubescence: } \\
\text { Leaf: }\end{array}$ & $\begin{array}{l}\text { Young parts rusty-tomentose. Blade } \\
\text { coriaceous, ultimately glabrous, ob- } \\
\text { long, obtusely acuminate, more or less nar- } \\
\text { rowed at the base with distinct lateral } \\
\text { veins, } 7 !-9 \mathrm{~cm} \text {. long, } 2 \frac{1}{2}-3 ! \mathrm{cm} . \text { wide, on } \\
\text { a } 16-20 \mathrm{~mm} \text {. long petiole. }\end{array}$ \\
\hline $\begin{array}{l}\text { Pedicels in fascicles of } 3 \text { or more, 12-18 } \\
\text { mm. long, recurved, staminodes shorter } \\
\text { than the stamens; (according to Engler's } \\
\text { key): lateral appendages shorter than } \\
\text { corolla-lobes; style short. }\end{array}$
\end{tabular}

Fruit:
Ellipsoid, glabrous, an inch long, seed obovate, compressed, subproduced at the base.
M. kirkii.

Twigs nearly glabrous. Blade coriaceous, glabrous, obovate-oblong, obtuse, cuneate at the base, with fine main veins, 5-10 $\mathrm{cm}$. Iong, 3-4! $\mathrm{cm}$. wide on a $15-25 \mathrm{~mm}$. long petiole.

Few together, on 12-20 mm. long arching pedicels; staminodes about as long as the stamens (according to Engler's key): lateral appendages about as long as corolla-lobes; "style much exerted from the corolla",

Globose, glabrous, an inch long; seed?

These differences appear to be very slight, and the most important ones seem to be the length of the lateral appendages, the length of the style and the shape of the fruit. However, subequal corolla-lobes and appendages can be found occuring with short staminodes and with longer ones, with short styles and with longer ones. The fruits in $M$. zeyheri vary from globose to ovoid and the seeds of fruiting specimens referred to $M$. kirkii (including the fruiting type specimen) in various herbaria show the characteristic produced base reported for $M$. zeyheri. Mr. B. de Winter compared specimens of Mimusops from the Transvaal with the type of $M$. kirkii and with authentic specimens of $M$. zeyheri at Kew and some of them correspond with either form, but there are intermediate specimens which link them up. The Rhodesian material I saw shows a complete continuous transition from the narrow leaved forms ( $=M$. zeyheri) to the broad-leaved forms $(-M$. kirkii), and the rusty pubescence of the innovations occurs in both forms. In my opinion the form which corresponds with $M$. zeyheri is the Bushveld ecotype and often shrubby, whereas the broad-leaved. form is a Lowveld ecotype (more tropical hence large trees), but there is no question about their specific identity.

Mimusops monroi S. Moore is a narrow-leaved form of "typical" M. zeyheri. Mr. de Winter kindly compared the type of M. monroi (Monro 761 in BM) and reported that it is an almost perfect match of Burke 72 from the Magaliesberg (in herb. Kew), which number is a "twin-type", practically identical with Zeyher 1130, the type of $M$. zeyheri, so that there is no doubt about the conspecifity of both species. Duplicates of Monro 76I in BOL and SRGH which I have seen are indistinguishable from most Transvaal specimens and certainly conspecific.

\section{EXCLUDED SPECIES OF MiMUSOPS.}

Mimusops altissima Engl. =- Muriea spec. [an Muriea discolor (Sond.) Hartog?], see p. 379.

M. angolensis Engl. = Manilkara cuneifolia (Baker) Dubard (a duplicate of the type, Welwitsch 4836 in COI, was studied).

M. buchananii Engl. = Muriea spec. (an M. discolor?, see p. 379).

M. concolor Harv. ex Wright $=$ Manilkara concolor (Harv. ex Wright) Gerstner. 
M. cuneata Engl. = Austromimusops cuneata (Engl.) A Meeuse, see p. 355.

M. cuneifolia Baker = Manilkara cuneifolia (Baker) Dubard.

M. densiflora Baker = Manilkara multinervis (Baker) Dubard (t. Engler and Hutch. \& Dalz.)

M. densiftora Engl. non Baker =- Manilkara mochisia (Baker) Dubard., see p. 369.

M. discolor (Sond) Hartog = Muriea discolor (Sond.) Hartog. see p. 344.

M. dispar N.E. Br. = Austromimusops dispar (N.E. Br.) A. Meeuse, see p. 352.

M. fischeri Engl. = Manilkara spec., prob. M. Mochisia (Baker) Dubard.

M. henriquesiana $\mathrm{Sim}=$ Lecomtedoxa henriquesii (Engl. et Warb.) A. Meeuse. see p. 344.

M. henriquesii Engl. et Warb. = Lecomtedoxa henriquesii.

M. Klaineana (Pierre ex) Engl. = Lecomtedoxa klaineana (Engl.) Dubard.

M. macaulayae Hutch. et Corb. = Manilkara macaularae (Hutch. et Corb.) H. J. Lam, see p. 373.

M. marginata N.E. Br. = Austromimusops marginata (N.E. Br.) A. Meeuse. see p. 348 .

M. menyhartii Engl. = Manilkara mochisia (Bak.) Dubard., see p. 369 .

M. mochisia Baker = Manilkara mochisia (Bak.) Dubard.

M. natalensis (Pierre) Engl. non M. natalensis Schinz = Muriea discolor, see p. 377.

M. natalensis Schinz $=$ Austromimusops marginata (N.E. Br.) A. Meeuse.

M. schinzii Engl. =- Austromimusops marginata (N.E. Br.) A. Meeuse.

M. spiculosa Hutch. et Corb. - Manilkara macaularae (Hutch. et Corb.) H. J. Lam.

M. silvestris S. Moore $=$ Austromimusops silvestris (S. Moore) A. Meeuse, see p. 354.

"M. transvaalensis Schinz" (sphalm.) ex Radlk. (recte: natalensis) = Austromimusops marginata (N.E. Br.) A. Meeuse.

M. umbraculigera Hutch. et Corb. = Manilkara macaulayae (Hutch. et Corb.) H. J. Lam.

M. welwitschii Engl. = Manilkara cuneifolia (Baker) Dubard.

M. zanzibarensis Engl. = Manilkara zanzibarensis (Engl.) Dubard.

\section{MANILKARA.}

Adans. emend. Gilly in Trop. Woods 73: 1-22 (1943); Lam \& Royen in Taxon. 2, 5: 112 (1953); Royen in Blumea 7: 401 (1953), nomen conserv. propos.

Manilkara Adans., Fam. PI. 2: 166 (1763); Dubard in Ann. Mus. Col. Marseille 23: 6 (1915); Baehni in Candollea 7: 462 (1938); Lam in Blumea 4: 323 (1941).

Mimusops pro parte. A.DC. in DC.. Prodr. 8: 203 (1844) (quoad sect. Ternaria ADC.); Bentham \& Hook., Gen. Pl. 2: 661 (1876); Baker in Oliv., Fl. Trop. Afr. 3: 505 (1877); Engl., Mon. Sapot. Afr. 55 (1904) (quoad section Euternaria Engl. exclus. Muriea); Wright in Dyer, Fl. Cap. 4, 1: 439, 1906: Phillips, Gen. S. Afr. Fl. Pl. ed. 2, 568 (1951). 
Trees or large shrubs. Stipules caducous or none. Leaves usually crowded at the tips of ihe branches; often more or less oblong-obovate with rounded (and emarginate) apex; lower side often lighter than upper one, mesophyll with sclereids; the nervation is usually parallel (tertiary nerves parallel to secondary ones), often causing a striate appearance of the leaf. Flowers axillary, usually in the axils of the lower leaves of the branches or of the scars of fallen leaves, 3-merous or occasionally 4-merous. Sepals biseriate, $3+3$ (or $4+4$ ), often rather broad. Corolla 6- (or 8)- lobed, each lobe (in the South African species) with two dorsal appendages. Stamens 6 (or 8), inserted in the throat of the corolla tube; filaments usually longer than the rather small anthers. Alternipetalous staminodes 6 (or 8), or sometimes fewer than the number of stamens, but never absent, usually small, often more or less dentate, lobed, fimbriate or divided, glabrous; not incurved and not covering the style as in Mimusops, but erect with the stamens of reflexed. with the corolla. Ovary 6- (or 8)-loculated, sometimes up to 15-loculated; ovules ventrally or basiventrally attached. Berry oneto several-seeded. Seeds more or less laterally compressed; testa crustaceous, brittle, or hard and bony; scar ventral, long and narrow, or basiventral and rather large and wide, rarely small, basal; endosperm copious, cotyledons thin, foliaceous.

Type species: Mimusops kauki L., Sp. Pl. ed. 1, 349 (1753)= Manilkara kauki (L.) Dub. in Ann Mus. Col. Marseille 23: 9 (1915), fide Van Royen in Blumea 7: 402.

Distribution.-Circumtropical; about 25 species in tropical America, about 30 in tropical Africa, South Africa and the Mascarenes and about 15 in the Far East and Pacific islands.

Manilkara is now almost universally recognised as a distinct genus. For a detailed discussion of the differences between this genus and Mimusops, cf. Lam., op. cit., 345-347. For the area under discussion, the main differences are given in Table II.

Both Manilkara and Mimusops have alternipetalous staminodes (which distinguish these two at once from Muriea, which has either 12 fertile stamens and no alternipetalous staminodes, or 12 sterile stamens), and both have seeds with endosperm, which distinguishes the two from Austromimusops apart from the very large seed scar in the latter. Gilly, in Trop. Woods 73 (1943), p. 1-22, extended the genus Manilkara by including Achras L. This would mean that Manilkara Adans. (1763) has to be replaced by Achras L. (1753) and all the old world. species of Manilkara apart from the American ones would have to be renamed. Gilly's interpretation is accepted by Lam and Van Royen who drew the consequences and proposed that it would be better to conserve Manilkara against Achras (see Taxon 2, 5: 112). In anticipation of adoption of this proposal for conservation, I retain the African representatives in Manilkara.

Twigs slender, not conspicuously zig-zag, divaricate or subverticillate; leaves not congested at the very tips of the branches;

Sepals 5-6 mm. long; staminodes about as long as the stamens, not fleshy, more or less irregularly serrate, incised or lacerate; leaves often more than $6 \mathrm{~cm}$. long and over $2.5 \mathrm{~cm}$. broad; petioles of ten more than $1 \mathrm{~cm}$. long........ 1. M. zanzibarensis.

Sepals about $3.5 \mathrm{~mm}$. long; staminodes usually shorter than the filaments, more or less fleshy, occasionally with a long apical filamentous portion; leaves usually less than $6 \mathrm{~cm}$. long and $2.5 \mathrm{~cm}$. broad; petioles $5-8 \mathrm{~mm}$. long.......... 2. M. concolor.

Twigs thick, conspicuously zig-zag, divaricate or subverticillate; leaves almost invariably crowded in fan-like groups at the very tips of the branches or on short lateral sideshoots; small trees resemblir $\mathrm{g}$ species of Terminalia:

Leaves quite glabrous, young one: very soon losing their pubescence; pedicels $8-12 \mathrm{~mm}$. long, sparingly pubescent; sepals sparsely pubescent outside........ 3. M. mochisia.

Leaves usually retaining vestiges of the dense pubesce of the young leaves, at least near the midrib or towards the base, rarely becoming quite glabrous; pedicels often more than $12 \mathrm{~mm}$. long; sepals tomentose outside........... 4. M. macaulayae. 
1. M. zanzibarensis (Engl.) Dub. in Ann. Mus. Col. Marseille 23: 26 (1915): Brenan \& Greenw., Tanganyika Terr. Check List. Mimusops zanzibarensis Engl. in Pflanzenw. O. Afr., C, 307 (1895), and in Mon. Sapot. Afr. 58, t. 21, Fig. B (1904), type: Stuhlmann coll. No. 1, 1009 in B. holot, from Zanzibar.

A large shrub or small tree up to $15 \mathrm{~mm}$. high. Branches terete, glabrous, faintly longitudinally striate or sulcate, the ultimate ones rather uniformly leafy. Leaves elliptic, or obovate-oblong to (elliptic-) oblong. $3-12.5 \mathrm{~cm}$., but usually $6-10 \mathrm{~cm}$.. long, $2-5 \mathrm{~cm}$. wide, coriaceous, rather opaque but sometimes shiny with a greyish or silvery shine beneath. glabrous, obtuse, rounded or sometimes emarginate at the apex. acute at the base, with distinctly reflexed margin; midrib immersed but often more or less keeled above, very prominent and when dry longitudinally finely striate or sulcate below; secondary nerves numerous (16-25 on either side), slender, impressed hence conspicuous above. far less conspicuous beneath. straight or ascending; tertiary nerves parallel to secondary ones, but somewhat thinner and often shorter; ultimate nervation fine, reticulate, immersed and conspicuous above. less conspicuous beneath. Petioles stout, terete, canaliculate above, $0 \cdot 5-3 \cdot 5$ but usually $1 \cdot 2 \mathrm{~cm}$. long. glabrous. in dried specimens more or less sulcate or striate below. Flovers trimerous, in fascicles in the axils of the leaves or of leaf-scars, few or many together; pedicels $5-8 \mathrm{~mm}$. long. more or less angular, densely and shortly rusty-pubescent. Sepals ovate-oblong to oblong, acute, 5-6 $\mathrm{mm}$. long; the outer ones about $3 \mathrm{~mm}$. wide, shortly rusty-pubescent outside and whitish-pubescent inside near the margins and near the apex, with a broad base; the inner ones thinner in texture, $2-3 \mathrm{~mm}$. wide. whitish-tomentose outside and glabrous inside except near the very apex, ciliate along the margins, with a narrower base. Corolla white, glabrous; the tube $2 \mathrm{~mm}$. long, the lobes linear-oblong, 4-5 $\mathrm{mm}$. at the apex, sometimes bifid and the lobes variously incised, glabrous. Filaments longsubulate, $\pm 2 \mathrm{~mm}$. long; anthers biapiculate, ovate-elliptic, about as long as the filaments. Ovary depressed semi-globose, about 10-loculated and more or less distinctly lobed, densely covered with greyish hairs, about $0.75 \mathrm{~mm}$. high and about $1.5 \mathrm{~mm}$. in diameter, very abruptly narrowing into the terete, glabrous, $5 \mathrm{~mm}$. long, truncate style. Fruit (according to Engler) obovoid. $10 \mathrm{~mm}$. long and $\pm 7.5 \mathrm{~mm}$. in diameter. $2-4$ seeded; seeds oblong, compressed $\pm 8 \mathrm{~mm}$. long. with a short cicatrix above the base.

N.B.-The figure A of tabula 21, B in Engler's monograph (1904) is not correct in that the flowers are drawn far too small although the legend mentions natural size. The other figures are properly drawn to scale.

General Distribution.-Coast of East Africa, from Zanzibar southwards and extending into the province of Niassa, Portuguese East Africa.

ZANZIBAR.-Imp. For. Herb. 834 leg. Vaughan (PRE).

TANGANYIKA.-Mafia Island, Greenway 5013, 5356 (PRE).

Portuguese E. Africa.-Niassa: between Macomia and Mipande near Pto. Amelia, Barbosa \& Lemos 2302 (LM); between Mahate and Metuge near Pto. Amelia, Barbosa 2346 (LM).

2. M. concolor (Harv. ex Wright) Gerstner [sphalm. (“E. Mey) Gerstner"] in J. S. Afr. Bot. 14: 171 (1948).

Mimusops concolor Harv. ex Wright in Dyer, Fl. Cap. 4. 1: 443 (1906); type: Gerrard \& Macken 1662 in TCD, holo, teste C. H. Wright, K. iso, from Zululand.

Although the combination " Manilkara concolor (Harvey) Gerstn." was erroneously published by Gerstner by putting "E. Mey" as the original author, it is evident from some of his notes and names on labels in the National Herbarium, Pretoria, that he actually meant the combination "Manilkara concolor (Harv.) Gerstn.", and he was credited as the author of this combination in the Index Kewensis. 
A much branched large shrub or small tree, up to $15 \mathrm{~m}$. but usually well under 10 m. high. Branches terete, greyish, more or less distinctly longitudinally fissured and with very prominent and large scars, the ultimate ones rather slender and almost invariably under $3 \mathrm{~mm}$. in diameter, soon quite glabrous. Innovations glabrous or at least very soon quite glabrous. Leaves crowded at the ends of the twigs but not strictly terminal as in the next two species, varying from obovate-oblong or narrowly spathulateoblong to oblanceolate-oblong, sometimes elliptic or elliptic-oblong, but usually narrowly spathulate-oblong or almost oblong (but with the greatest width just above the middle), $2-5 \mathrm{~cm}$., rarely up to $8 \frac{1}{2} \mathrm{~cm}$. long and $1-2(-3 \cdot 5) \mathrm{cm}$. wide, coriaceous, glabrous, with subreflexed margin an emarginate or retuse, rarely rounded apex, and narrowed, but never very acute, base; midrib slightly raised or subimmersed, flush or minutely keeled, but always narrow above, rather prominent below; secondary nerves very slender, inconspicuous or more or less conspicuous because they are impressed on both sides. 10-15 on either side, parallel, straight or rather straight, and ascending at an angle of $60^{\circ}-90^{\circ}$; tertiary nerves rather few, parallel to but shorter than the secondary ones; ultimate reticulate tessellate nervation fine, immersed on both sides and as a rule distinct or conspicuous. Petiole semi-terete, flattened and channelled above, rather stout, $3-8 \mathrm{~mm}$. long, glabrous. Flowers in the axils of the leaves and of scars of fallen leaves, fasciculate, often very numerous, 3-merous or sometimes 3-merous and 4-merous on one specimen; pedicels comparatively stout, terete or sub-glabrous, abruptly widening into the calyx, Sepals ovate or ovate-elliptic, obtuse, about $3 \cdot 5$ $\mathrm{mm}$. long; the outer ones tomentose outside and inside near the apex, $2-2.5 \mathrm{~mm}$. wide; the inner ones thinner, petaloid, slightly narrower, about $2 \mathrm{~mm}$. wide, vaguely midribbed, whitish tomentose outside, glabrous inside. Corolla yellow or yellowish, glabrous; the tube $0.75-1 \mathrm{~mm}$. long, the lobes oblong-linear or oblanceolate-spathulate, obtuse or rounded, with a very narrow, base, $3 \cdot 3-5 \mathrm{~mm}$. long and about $0.75 \mathrm{~mm}$. wide; the appendages about as long and wide, but from a broad base lanceolate-linear, acute or acuminate, often with a few coarse serrations near the apex. Staminodes sometimes fewer than the number of calyx-lobes, glabrous, fleshy, usually ovate-suborbicular or subquadrate, and much shorter than the filaments, usually more or less trilobed or tridentate. occasionally some produced in a thin filiform apical portion equalling the filaments and if so. equalling or longer than the stamens. Filaments 1.5-2 mm. long, glabrous; anthers somewhat sagittate, apiculate, $1-1 \cdot 5 \mathrm{~mm}$. long. Ovary 6- (or 8-) loculated, semiglobose-conical, faintiy lobed, hairy, nearly $1 \mathrm{~mm}$. long and about $1.25 \mathrm{~mm}$. in diameter, more or less gradually passing into the rather thick, subulate, glabrous and truncate, about $2.5 \mathrm{~mm}$. long style. Fruiting pedicels not or hardly lengthened, somewhat incrassate; calyx persistent. Berry 1-or 2-seeded, edible, ellipsoid or subglobose, $10-15 \mathrm{~mm}$. long and $8-15 \mathrm{~mm}$. in diameter. Seeds obovoid, hardly compressed when single, often with one flattened lateral side when from a 2seeded fruit, obliquely truncate at the base, $9-11 \mathrm{~mm}$. long $6 \frac{1}{2}-8 \mathrm{~mm}$. wide, those from 1-seeded fruits 5-7 mm. thick, those from 2-seeded fruits 3-5 mm. thick; testa brown, smooth and shiny, hard; scar ovate, oblong or elliptic, occupying the truncate basilateral side of the seed, $6-8 \mathrm{~mm}$. long and $3 \mathrm{~mm}$. wide.

NATAL.-Kranskop: Tugela near Jameson's Drift, Bayer 648 (NU). Mtonjaneni: Mtonjaneni, Gerstner 3710 (NH, PRE); Fule Drift near junction with Umhlatuzi, Gerstner 2735 (BOL). Lower Umfolozi: Umsindusi Bridge, West 1873, 1911 (NH); Empangeni, Nagana Res. St., Kluge 30 (NH); Umfolozi Game Reserve, Ward 1467 (NH, PRE). Hlabisa: Duku-Duku forest, Forest Dept. FD h. No. 8603 (Pre, SAFD); near Matubatuba, Gerstner 8974 (NH, PRE); Hluhluwe Game Reserve, Ward 1593 (NH, PRE); False Bay, Gerstner 4791, 5061 (NBG, PRE), 5235 (PRE). Nongoma: about $13 \mathrm{~m}$. N. of Nongoma on road to Magut, Acocks 13015, Codd 1943 (PRE); Wendelane Kloof. Gerstner 2522 (BOL), 4683 (NBG, PRE). Ubombo: Mkusi, Galpin 13319 (PRE). 
Portuguese East Africa.-Sul do Save; Lourenço Marques distr., Maputo, Santaca, Gomes e Sousa 3799, 3819 (COI, PRE), 3861 (PRE).

3. M. mochisia (Baker) Dub. in Ann. Mus. Col. Marseille 23: 26 (1915); Gerstner in J. S. Afr. Bot. 14: 171 (1948), sphalm. "(Baker) Gerstner". Mimusops mochisia Baker in Oliv., Fl. Trop Afr. 3: 506 (1877); Engl., Mon. Sapot. Afr. 63, t. 22, Fig. B (1904); type: Kirk 304 from Tete, K, lecto.; fragment in PRE!.

Mimusops densiflora Engl., Pflanzenw. O.-Afr.. C, 307 (1895), and in Mon. Sapot. Afr. 63, t. 22, Fig. C (1904), non Baker in Kew Bull. 1895: 148; type: Stuhlmann coll. No. 581 in herb. Hamburg, lecto.

Mimusops menyhartii Engl., op. cit. (1904), 63, t. 23. Fig. D; type: Menyhart 771 from Boruma in Z, holo., PRE, photo!.

“Manilkara densiflora Engl.", Dale, in Imp. Forestry Inst. Paper 18: 25 (1939): M. densiflora Dale. q.e. nom. nov., ex Brenan and Greenw., Check list Tanganyika Terr. 2: 563 (1949). M. densiflora (Engl.) H. J. Lam in Blumea 4, 2: 355 (1941). nomen illeg. M. menyhartii (Engl.) H. J. Lam. op. cit.. 356.? Sideroxylon fischeri Engl. in Pflanzenw. O. Afr.. C, 306(1895). = Mimusops fischeri (Engl.) Engl.. Mon. Sapot. Afr. 64 (1904). = Manilkara fischeri (Engl.) Lam in Blumea 4: 355 (1941).

A much branched deciduous large shrub or small to medium-sized tree, up to $10 \mathrm{~m}$., rarely up to $15 \mathrm{~m}$., high, with divaricate, subverticillate or zig-zag wise arranged, often crooked branches, resembling several African species of Terminalia in habit. Branches dimorphous; main shoots rather long (internodes usually 5-10 cm. long); "lateral" short branches usually under $20 \mathrm{~mm}$. long; internodes of main shoots terete, rather smooth, finely longitudinally sulcate and, if not very young, glabrous and over $3 \mathrm{~mm}$. thick. only the very young growing ones bearing a few leaves that are not strictly terminal. Short shoots and apices of the branches frequently somewhat thicker than the adjoining internodes, very rough with the scars of fallen leaves; youngest shoots at first pale yellowish- or whitish-tomentose, glabrescent. (New shoots are formed laterally under the terminal thickened and leaf-bearing portions of the branches and and this causes the peculiar divaricate or subverticillate branching, the original terminal portion becoming a short "lateral" branch). Leaves in rather dense, more or less fan-wise spreading groups on the short lateral branches and terminal apices (apparently both lateral and terminal thickened portions of the stems being able to produce young leaves during several season in succession); young leaves almost completely glabrous as soon as they appear, the older ones quite glabrous; blade narrowly elliptic-obovate, narrowly spathulate-oblong, cuneate-oblong or more or less oblanceolate-oblong, sometimes obovate-oblong, $1 \cdot 5-4(-6) \mathrm{cm}$. long and $0 \cdot 75-2(-2 \cdot 75) \mathrm{cm}$ wide, coriaceous, or subcoriaceous, with a usually distinctly emarginate or retuse, sometimes rounded, apex, and narrowing towards the base, with minutely reflexed margins, drying greyishgreen, paler beneath; midrib usually not very prominent on either side, but as a rule flush or slightly immersed above and slightly prominent beneath, distinct and discolorous in dried specimens; lateral nerves slender, immersed, ascending at an angle of $45^{\circ}-60^{\circ}$; secondary nerves rather numerous (10-15 on either side), tertiary nerves not or hardly discernible from the ultimate, fine, impressed, reticulate nervation. Petioles $2-4 \mathrm{~mm}$., rarely up to $7 \mathrm{~mm}$., long. flattened above, on either side minutely winged by a continuation of the leaf margins. Flowers trimerous (at least no 4-merous ones seen), often appearing with the young leaves or just before the leaves, solitary or in fascicles in the axils of fallen leaves below the young growths; pedicels and calyx greenish or green tinged with brown. Pedicels $8-12 \mathrm{~mm}$. long, rather slender, more or less angular, sparingly whitish pubescent, abruptly widening into the calyx. Sepals $3+3$; the 
outer ones ovate, sometimes oblong, 4-5 mm. long, 2.5-3 $\mathrm{mm}$. wide, sparingly pubescent outside, pubescent inside near the apex and margins; the inner ones more petaloid, oblong, 4-4.5 mm. long and 2-2.5 mm. wide, acute, tomentose outside, glabrous inside, vaguely midribbed. Corolla glabrous; the tube about $1 \mathrm{~mm}$. long; the lobes elliptic-lanceolate from a narrow base, obtuse or rounded; about $4 \mathrm{~mm}$. long and $0 \cdot 75-1 \mathrm{~mm}$. wide, the appendages about as long, linear, obtuse or rounded, $0 \cdot 5-0 \cdot 75$ mm. wide. Staminodes variably in size but usually much shorter than the filaments, rather fleshy, subquadrate, ovate or spathulate, trilobed, tridentate, bifid or incised. occasionally produced at the apex in a long subulate or filamentous appendage equalling the filaments, rarely even longer. Filaments long-subulate, about $2.5 \mathrm{~mm}$. long, anthers oblong: apiculate, about $1.5 \mathrm{~mm}$. long. Ovary 6-loculated, semiglobose-conical, about $1 \mathrm{~mm}$. high and about $1.5 \mathrm{~mm}$. in diameter, densely covered with rather long hairs which also cover the base of the about $3 \mathrm{~mm}$. long, subulate, terete, glabrous, truncate style. Fruiting pedicels hardly lengthened, somewhat incrassate, fruiting calyx persistent Berry ellipsoid or ellipsoid-obovoid, yellow when ripe, highly appreciated by natives

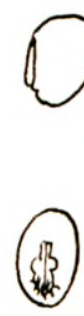

15
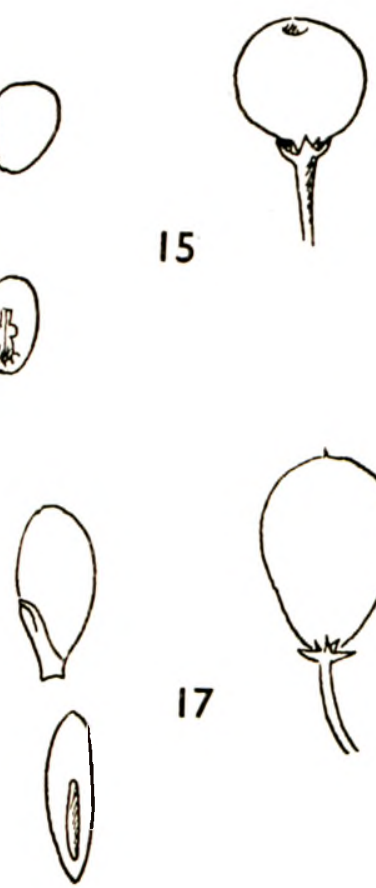

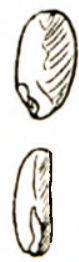

16
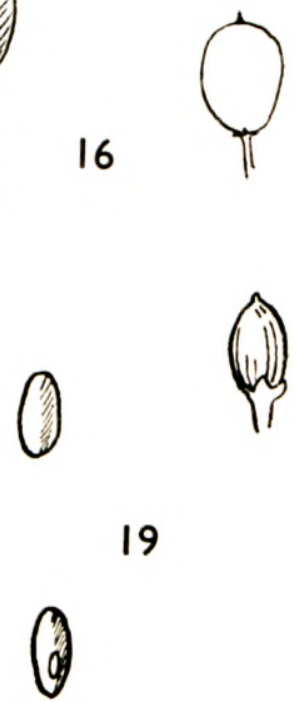

19

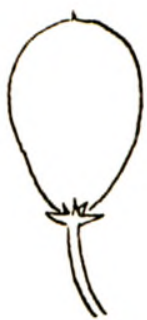

FIG. 15.-Manilkara concolor, seed and fruit (from Gerstner 3759, " Nangusi Forest", Zululand, in $\mathrm{NH}$ ).

FIG. 16.-Manilkara mochisia, seed and fruit (from Wild 2748, Ndanga, S. Rh., in SRGH).

FIG. 17.-Manilkara macaulayae, seed and fruit (from Lovemore 250, Sebungwe, S. Rh., in SRGH).

FIG. 19.-Muriea discolor, seed and fruit (from Wood 1349, Inanda, Natal, in NH). 
and baboons for the flavour, $10-12 \mathrm{~mm}$. long and 8-10 $\mathrm{mm}$. in diameter, those I have seen 1-3 seeded. Seed brown, obovate-oblong or oblong, compressed, $8-11 \mathrm{~mm}$. long, 5-7 $\mathrm{mm}$. wide and 3-4 $\mathrm{mm}$. thick, sub-produced at the base; testa brown, rather smooth, not very shiny, hard; scar basilateral, linear-elliptic or linear, 3-5 mm. long and $0 \cdot 5-1 \cdot 5 \mathrm{~mm}$. wide, surrounded by a rather wide, pale brown, callus-like zone which includes the whole subproduced base of the seed.

A type specimen was originally not designated, as Baker, l.c., mentions two specimens, via., a specimen from Batoka country, N. Rhodesia and one collected near Tete (Zambezia. P.E.A.), both leg. Kirk. As Engler only mentions the specimen from Tete in his monograph. I propose to make this one the lecto-type (in herb. Kew.) (NH).

Natal.-Umbombo: Otobotini, near Ndumo Game Reserve, Gerstner 3438

Swaziland.-Probably near Stegi, Pole Evans $3488(=66)$.

Transvaal.--Nelspruit: Kruger National Park. Skukuza, Codd \& deWinter 4992. van der Schiiff 1262. Pretoriuskop, v. d. Schijff 2014; Mbeyamide. v. d. Schiiff 2044 , 1136. Pilgrims Rest: Kruger National Park, near Skukuza Codd 4388: Nwanetsi, v. d. Schijff 320. Letaba: Kruger National Park, near Shingwedsi. Codd \& Dier 4660; near Letaba, Lamont 33. Sebasa: Punda Maria Codd 4238, Codd \& Dyer 4537. v. d. Schiiff 568, 570; Nuanetsi, Gerstner 6061 (all PRE).

Portuguese E. Africa.-Sul do Save: Maputoland. Pto. Henrique, Gersiner 6670 (PRE); Lourenço Marques, Borle 144 (PRE): nr. Macia, Pedro \& Pedrogão 1442 (PRE); nr. Chibuto, Pedro \& Pedrogão 1535 (PRE); Guiza, Pedrogão 348 (PRE); nr. confluence of Limpopo and Nuanetzi Rivers (nr. Transvaal border); Smuts P. 332 (PRE); Maringua, Sabi Riv., Chase 2454 (SRGH). Zambesia: Tete, Kirk 304 (fragment of type in PRE, ex herb. Kew); id., Baroma, Sisitso Riv.. Chase 2753 (SRGH); Menyhart 771 (Z, photo PRE!, holotype of M. meny.hartii Engl.).

Southern Rhodesia.-Ndanga: Wild 2748 (SRGH); Chase 2367 (SRGH). Chipinga: Makosa Hills, Phelps 200 (PRE, SRGH). Melsetter: Chase 1767 (SRGH). West Nicholson: Plowes 1524 (PRE, SRGH).

Nyasaland.-Chiromo: Homby 2902 (PRE).

TANGANyIKA.-Lindi: Lake Lutamba, Schliehen 5500 (PRE). In addition, the following material was kindly sent on loan from the E. African Herbarium, Nairobi, which I refer to this species:

TAnganyika Territory.--Moa-Mwakijembe: Kermode AH9930. Tabora: Forest Guard Tabora 1517.

Kenya.-Bura, Tana Riv.: Bally B2805. Kitui Distr., Nzui; Edvards E79. Coast, Kiunga: Elliott OX 888; N. Giriama: Kale K 3663. Kibwezi: Gibbons K2571.

Engler describes Mimusops mochisia in his monograph as having staminodes often bearing a long filamentous portion at the apex (Engler, op. cit., 1904, t. 22, Fig. B, d, and in the description, op. cit., 63: "staminodiis e parte basali subquadrati in appendicem filiformem filamenta aequantem saepe productis”). Baker (l.c.) does not mention 
the filiform appendages, but describes " 6 minute toothed petaloid cuneate truncate glabrous staminodes". Miss Kies, our officer stationed at Kew in 1950, examined one of the original specimens (leg. Kirk at Tete), and reported that this specimen does not possess the filamentous appendages (at least not in the flowers she dissected). Upon examination of a fragment of the specimen Kirk 304 from Tete, kindly sent through the courtesy of the Keeper of the Herbarium at Kew, I came to the same conclusion. In my opinion, the shape of the staminodes in this group of Manilkara (Section Isogyne of Engler, op. cit., 1904) is not a constant character. Both in Manilkara concolor and in $M$. macaulayae a great variation in the shape of the staminodes is found, from small and subsquamiform to long-subulate, or some having filamentous appendages (see Fig. 17), and in the few flowering specimens of $M$. mochisia I could examine, several different forms of staminodes were found: trilobed, spathulate, dentate, bifid, etc. Apart from the differences in the shape of the staminodes, the differences mentioned by Engler between $M$. mochisia, $M$. densiflora and $M$. meny/2artii are negligible. The leaf-shape reported for $M$. menyhartii is frequently found on specimens also having some longer and narrower leaves. The three type specimens are evidently only forms of one rather variable species, and Mimusops mochisia Baker being the oldest name. the name Manilkara mochisia (Baker) Dubard applies to all three forms under discussion. A syntype, which I propose as the lecto-type, of Mimusops densiftora Engl. non Baker is still extant (in herb. Hamburg) and was compared by Mr. de Winter with specimens of $M$. mochisia. He reported that they are identical. An isotype of $M$. menyhartii in herb. Zürich also proved to be a. good match.

Mimusops fischeri (Engl.) Engl., the type of which was destroyed during the last war and of which no isotypes could be traced, is most probably closely related to $M$. mochisia but I hesitate to refer it to this species, because in the description of $M$. fischeri. the innovations are reported to be densely tomentose, whereas the older leaves are said to be glabrous. The young parts of $M$. mochisia are never densely tomentose in the specimens I have seen and on the other hand the older leaves of M. macaulayae, which species also comes into consideration, are very rarely quite glabrous, but may by an oversight have been described as glabrous in Engler's description. The old leaves are described as coriaceous which applies to $M$. mochisia rather than to M. macaulayae. The pedicels of the type specimen, which was in bud, were described as 3-6 $\mathrm{mm}$. long, which points to $M$. mochisia rather than to $M$. macaulayae. Upon my request, Dr. B. Verdcourt of the East African Herbarium, Nairobi, sent me their material labelled $M$. densiflora. The specimens in question, including those from the type area of $M$. fischeri, proved to be $M$. mochisia and did not include specimens referable to $M$. macaulayae. For these reasons the identity of Mimusops fischeri Engl. remains somewhat uncertain, but the evidence is mostly in favour of $M$. mochisia, and I therefore regard. Mimusops fischeri as a probable synonym of $M$. mochisia.

The history of the name of Manilkara densiflora is interesting from a nomenclatural point of view, although the name falls into synonomy. Engler and Baker published the binomial Mimusops densiflora almost simultaneously, but for different plants. Baker's name (in Kew Bull. 1895, p. 148) antedates Engler's [Pflanzenw. Ost-Afr., C. (1895), p. 307]. Strictly speaking, all combinations based on Engler's name are invalid, but of course the name densiflora, not being preoccupied in Manilkara, can still be used for this species. Brenan and Greenway, therefore, took up the combination made by Dale as a "new name", Manilkara densiflora Dale. Mimusops densiflora Baker was reduced to Mimusops multinervis Baker by Engler in his Sapotaceae monograph, and 
Mimusops densiflora Engler, as was pointed out above, becomes a synonym of Manilkara mochisia. $M$. mochisia is closely related to $M$. concolor and $M$. macaulayae, and resembles especially the latter very much in habit. There is no doubt that they represent three distinct species which can be distinguished as follows:

\begin{tabular}{|c|c|c|c|}
\hline & M. concolor. & M. mochisia. & M. macaulayae. \\
\hline $\begin{array}{l}\text { Arrangement of } \\
\text { leaves }\end{array}$ & $\begin{array}{l}\text { Older leaves not strictly ter- } \\
\text { minal, no short thick lateral } \\
\text { shoots bearing leaves. }\end{array}$ & $\begin{array}{l}\text { Older leaves strictly ter- } \\
\text { minal, and on very short } \\
\text { thick lateral shoots. }\end{array}$ & As in $M$. mochisia. \\
\hline Pubescence.... & Leaves quite glabrous. . & Leaves quite glabrous & $\begin{array}{l}\text { Leaves usually more or } \\
\text { less pubescent: older ones } \\
\text { rarely quite glabrous. }\end{array}$ \\
\hline Seeds......... & $\begin{array}{l}\text { Rather small, brown, } \\
\text { smooth and shiny, not or } \\
\text { hardly compressed, } 9-11 \\
\text { mm. long, and } 5-7 \text { mm. } \\
\text { thick (if one seed per fruit) } \\
\text { or } 3-5 \text { mm. thick (more } \\
\text { seeds per fruit). }\end{array}$ & $\begin{array}{l}\text { Rather small, brown, } \\
\text { rather smooth, not very } \\
\text { shiny, much compressed, } \\
9 \frac{1}{2}-11 \text { mm. long and } 3-4 \\
\text { mm. thick. }\end{array}$ & $\begin{array}{l}\text { Rather large, greyish- } \\
\text { brown, not smooth, dull. } \\
\text { much compressed, about } \\
16 \mathrm{~mm} \text {. long and } 3 ! 4 \\
\mathrm{~mm} \text {. thick. }\end{array}$ \\
\hline Scar......... & $\begin{array}{l}3 \mathrm{~mm} \text {. wide, not sur- } \\
\text { rounded by a callouslike } \\
\text { zone. }\end{array}$ & $\begin{array}{l}\frac{1}{2}-1 \frac{1}{2} \mathrm{~mm} \text {. wide, sur- } \\
\text { rounded by a rather wide } \\
\text { callus-like zone which in- } \\
\text { cludes the whole sub-pro- } \\
\text { duced base of the seed. }\end{array}$ & $\begin{array}{l}\frac{1}{2}-1 \mathrm{~mm} \text {. wide, surround- } \\
\text { ded by a callus-like zone. } \\
\text { which includes the whole } \\
\text { produced base of the seed. }\end{array}$ \\
\hline
\end{tabular}

Although $M$. mochisia and $M$. macaulayae are distinct species, it is difficult to distinguish specimens of the latter with only glabrous old leaves from $M$. mochisia. In this case the additional characters used in the key, viz., the length of the pedicels and the pubescence of the calyx, can be used to distinguish them.

4. M. macaulayae (Hutch. et Corb.) H. J. Lam in Blumea 4: 356 (1941).

Mimusops macaulayae Hutch. et Corb. in Kew Bull. 1924: 329,330, fig. A (1924); type: MacAulay 1002 from Northern Rhodesia in K, holo; fragment in PRE. M. spiculosa Hutch. et Corb., op. cit., 330, 331, Fig. B., type: Allen 185 from Victoria Falls in K, holo; BOL! and PRE!, isos. M. umbraculigera Hutch. et Corb. l.c., and Fig. C (p. 330); type: N.N. from Southern Rhodesia in K, holo. $=$ SRGH No. 2639, iso!.? Mimusops fischeri (Engl.) Engl., Mon. Sapot. Afr. 64 (1904).

Manilkara spiculosa (Hutch. et Corb.) H. J. Lam, I.c., and M. umbraculigera (Hutch. et Corb.) H. J. Lam, I.c.

A small to medium-sized deciduous tree up to about $15 \mathrm{~m}$. high. with divaricate. subverticillate or zig-zag wise arranged, often crooked branches. Branches dimorphous: main shoots rather long (internodes usually $5-10 \mathrm{~cm}$. long), lateral short branches usually $+5-15 \mathrm{~mm}$. long, rarely longer; internodes of main shoots terete, rather smooth with faint longitudinal fissures, striations or wrinkles and (if not very young) glabrous and at least $3-6 \mathrm{~mm}$. thick, and only the very young ones bearing a few leaves that are not strictly terminal; short shoots and apices of branches frequently thicker than the adjoining internodes, very rough with the close scars of fallen leaves; youngest shoots at first densely yellowish- or pale rusty-tomentose, 
glabrescent. (New branches are formed under the terminal thickened portions of the branches and this causes the peculiar divaricate or subverticillate appearance, the original terminal portion becoming a short lateral branch). Innovations, young leaves (mainly below), pedicels and outside of calyx-lobes with a pale buff pubescence, the latter often, and on the leaves always, turning white. Leaves in rather dense, more or less fan-wise spreading groups on the short lateral branches and. terminal apices (apparently both terminal and lateral thickened portions of the stems being able to produce young leaves in several seasons in succession); blade narrowly elliptic-obovate to narrowly spathulate-oblong or more or less cuneate-oblong, usually rather narrow, $3-5(-7 \cdot 5) \mathrm{cm}$. long and $1-2(-3) \mathrm{cm}$. wide, with a usually distinctly emarginate or retuse, sometimes rounded apex, narrowing to the base, with minutely reflexed margins, rather firm but not coriaceous ( $M$. mochisia has more coriaceous leaves as a rule), drying an opaque green or brown, slightly paler beneath, densely tomentose or pubescent when young, at least on the lower surface, very rarely becoming quite glabrous, but usually at least retaining vestiges of an adpressed whitish pubescence beneath, especially near the midrib and towards the base; midrib either slightly raised or slightly immersed, flush or minutely keeled and not very wide above, prominent beneath, usually discolorous in dried specimens; secondary nerves slender, often inconspicuous, rather numerous ( \pm 10 to 15 on either side), parallel and straight, ascending at an angle of about $60^{\circ}$, faintly raised above, subimmersed below, usually bifurcate well inside the margin and their ramifications soon merging with the finer reticulate nervation; tertiary nerves not or hardly descernible from the very fine, tessellate, reticulate nervation which is always distinct in older leaves. Petioles flattened and canaliculate 3-7 (-10) $\mathrm{mm}$. long, glabrescent but as a rule never becoming quite glabrous. Flowers often appearing with or just before the young leaves, solitary or in small fascicles in the axils of fallen leaves below the young growths; pedicels and calyx of a greenish-fawn or buff colour. Pedicels often more than $12 \mathrm{~mm}$. long, rather slender and faintly angular, abruptly widening into the calyx. Sepals $3+3$ or sometimes $4+4$; those of the outer and inner rows subequal, ovate-elliptic (3-) $4 \mathrm{~mm}$. long and (2-) $3 \mathrm{~mm}$. wide, but the outer ones with a broad base, the inner ones slightly thinner in texture, with a narrower base and the greatest width just above the middle, all obtuse, tomentose outside, glabrous inside except near the apex. Corolla glabrous, probably yellow or yellowish; the tube less than $1 \mathrm{~mm}$. long, the lobes and lateral appendages subequal, oblonglanceolate, 3-4 long and $\pm 1 \mathrm{~mm}$. wide, rounded or obtuse at the apex. Staminodes sometimes fewer than the number of calyx-lobes, usually much shorter than the filaments but sometimes nearly as long, glabrous, very variable in shape, varying (often in one specimen or even in one flower) from triangular, trilobed, tridentate or subquadrate to oblong, irregularly dentate or serrate to linear-subulate or subulate from a sub-quadrate or semi-orbicular basal portion. Filaments subulate or linear-terete, 1.5-2 mm. long; anthers ovate-oblong or ovate-lanceolate, $1 \cdot 5-2 \cdot 5 \mathrm{~mm}$. long. Ovary 6-(or 8-)-loculated, ovoid-globose, more or less angular, $1 \frac{1}{4}-1 \frac{3}{4} \mathrm{~mm}$. long and $1-1 \frac{1}{4} \mathrm{~mm}$. in diameter, pubescent, more or less gradually tapering into the glabrous, long-subulate, angular to subterete and minutely truncate, $3-4 \mathrm{~mm}$. style. Fruiting pedicels lengthening and up to $25 \mathrm{~mm}$. long, slightly incrassate and ultimately about $1 \mathrm{~mm}$. thick, glabrescent; calyx under fruit persistent. Berry ellipsoid or obovoid-oblong, with a narrow base, about$18 \mathrm{~mm}$. long, 8-10 mm. in diameter, edible, the few seen all one-seeded. Seed obovate oblong, compressed, $\pm 16 \mathrm{~mm}$. long, $\pm 7 \mathrm{~mm}$. wide and $3 \frac{1}{2}-4 \mathrm{~mm}$. thick, narrowed and more or less unequal at the base, laterally produced at the side of the scar; testa a dull greyish brown, more or less rugose, or tuberculate, hard; scar linear, $\pm 8 \mathrm{~mm}$. long and $0 \cdot 5-1 \mathrm{~mm}$. wide, surrounded by a light brown and rather shiny, slightly thickened zone which is about $12 \mathrm{~mm}$. long and about $3 \mathrm{~mm}$. wide and includes the whole produced base of the seed.

ANGOLA.-Caposolo: Faulkner (A) 64 (PRE). 
Bechuanaland.-Chobe: Serondela. O. B. Miller B/1128, B/1203, (PRE). Kachikau on road to Kasane, Erens 380 (PRE, SRGH). Small island in marches near Ghanzi. 22' 30' E, $19^{\circ} 5^{\prime}$ S: Story 4789 (PRE).

Southern Rhodesia.-“"Matabeleland”: Mrs. Pardy s.n. (SRGH No. 5027). Urungwe: Wild 4163 (PRE, SRGH). Sebungwe: Lovemore 250 (SRGH). Hartley: Umswewe River, Hodgson H. $35 / 48$ (SRGH); Gatooma, Golding s.n. (SRGH No. 31015, 31267); Eyles in QVM. Herb. No. 7264, 7507 (SRGH); Hartley: Eyles in QVM. Herb. No. 7507 (SRGH). Wankie: Wankie Camp. Pole Evans 2751 (PRE. SRGH); Victoria Falls, Allen 185 (isotype of Mimusops spiculosa. Hutch et Corb., (PRE, BOL); Galpin 7052 (PRE); Wild 3088, 3106 (SRGH). Bulawayo: Hodgson s.n. (PRE, SRGH). Without precise locality: N.N. in SRGH 2639 (isotype of Mimusops umbraculigera Hutch. et Corb.); specimen sent by Dept. of Munitions, S. Rh., to Bolus Herb (BOL. 25013).

Northern Rhodesia.-Victoria Falls, N. bank, Pole Evans 2751 (8) (PRE, SRGH) Lusaka: Mumbura. MacAulay 1002 (fragment of type of Mimusops macaularae, PRE).

A study of the few flowering specimens I have seen (including a fragment of the type specimen and, in addition, isotypes of Mimusops spiculosa and $M$. umbraculigera) showed that the staminodes are very variable in shape and length and that in a single flower triangular, serrate, bifid, dentate and subulate ones may occur (Fig. 18). In the isotype of $M$. umbraculigera, I found bifid and triangular staminodes apart from the irregularly dentate ones described in the species diagnosis by Hutchinson and Corbishley: in the isotype of $M$. spiculosa bifid ones occur apart from the subulate ones mentioned in the original species diagnosis. In Faulkner (A) 64 such a great variation is found (see Fig. 18), that I am convinced that the three species described by Hutchinson and Corbishley, are conspecific. Apart from the character of the staminodes, the differences they mentioned are very slight and as far as I have seen, not constant (such as the shape of the filament, relative lengths of filaments and anthers, pubescence) so that there is no reason to distinguish more than one species. As regards the possible identity with Mimusops fischeri Engl., see the discussion under Manilkara mochisia.

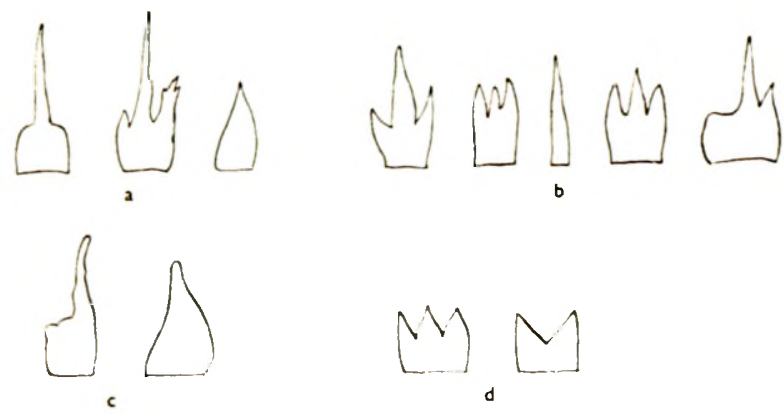

F:C. 18.- Shapes of staminodes in Manilkara macaulayae: (a) 3 staminodes found in one flower of Faulkner (A) 64 from Angola; (b)5 staminodes of another flower of the same specimen; (c) 2 staminodes from isotype of Mimusops umbraculigera (SRGH No. 2639 from Rhodesia); (d) 2 staminodes out of one flower of $O$. B. Miller B/1128 from Bechuanaland. 


\section{MURIEA}

Hartog in J. Bot. 16: 145 (1878) (diagnosis on p. 72 sub. Eichleria Hartog); Dubard in Ann. Mus. Col. Marseille 23: 28 (1915); H. J. Lam in Blumea 4: 348 (1941) and Table I (p. 350). Eichleria Hartog in J. Bot. 16: 72 (1878), non Eichleria Progel in Mart., Fl. Bras. 12, 2: 518 (1877).

Labourdonnaisia Boj. ex parte, Benth. \& Hook, Gen. Pl. 2: 659 (1876); Gerstner in J. S. Afr. Bot. 12: 40 (1946).

Mahea Pierre, Not. bot. Sapot. 8 (1890).

Mimusops L. sect. Muriea Hartog in J. Bot. 17: 358 (1879).

Mimusops L., subgenus Ternaria (A. DC) Engl., sect. Euternaria Engl., subsect. Muriea (Hartog) Engl. in Mon. Sapot. Afr. 55 (1904), and sect. Mahea (Pierre) Engl., op. cit., 65.

Mimusops L., ex parte, C. H. Wright in Dyer, Fl. Cap. 4, 1: 439 (1909), p. 439; Phillips in Genera S. Afr. Flow. Pl., ed. 2: 568 (1951).

Type species: Labourdonnaisia discolor Sond. in Linnaea 23: 73 (1850) = Muriea discolor (Sond.) Hartog.

Trees with exstipulate, parallel-nerved leaves. Flowers trimerous, axillary, solitary or in fascicles. Sepals $3+3$; corolla with short tube and 6 lobes, these lobes either bearing two lateral appendages (in this case 12 fertile stamens, sub-biseriate: 6 epipetalous and 6 alternipetalous) or the lateral appendages reduced, sometimes 0 (in this case usually stamens more or less sterile and transformed into subulate staminodes). Stamens inserted in the throat of the corolla tube. Ovary 6-loculated, hairy; style long-cylindric-subulate; ovules with basal or basilateral attachment. Berry (always?) l-seeded. Seed with basilateral, oblong or elliptic scar; testa rather thin and brittle; endosperm copious; cotyledons thin, foliaceous.

Number of species: At least one in the coastal regions of Southern East Africa, possibly one or two more in tropical East Africa (if not conspecific with the first) and, according to Hartog (1878) and others, another species in the West Indies.

The nomenclature of the type species Muriea discolor (Sond.) Hartog is rather complicated. Sonder described it as a Labourdonnaisia and it was included in this genus by Bentham and Hooker in Gen. Pl. 2: 659. Hartog (1887) pointed out that the petals in Labourdonnaisia are equal and placed in one whorl, their number varying from 12-17, with an equal number of stamens, whereas the species described by Sonder has 6 corolla lobes with each 2 lateral appendages. On account of this difference, among other things, Hartog decided that the plant belongs to a different genus, which he described as Eichleria. This name being illegitimate on account of Eichleria Progel, Hartog changed the name to Muriea. A year later, he regretted this decision and included his genus Muriea as a section in his large genus Mimusops which comprised practically all the Sapotaceae-Mimusopoideae. Engler (1904). whose conception of Mimusops agrees with that of Hartog, included Muriea as a subsection of his section Euternaria (the greater part of which is now generally recognised as belonging to the genus Manilkara Adans.)

Dubard in 1915 resuscitated Muriea, which genus he placed near his section Mahea of Manilkara, on account of the absence of staminodes.

Baehni in Candollea 7: 467 (1938), reduces Muriea to Mimusops, which is altogether incomprehensible to me, because Baehni, op. cit., 465-466 excludes all forms with 3-merous flowers from Mimusops (and includes most of them in Manilkara).

Mahea Pierre remained a more or less problematic genus for a long time. Engler (1904) reduced it to a section Mahea of a large genus Mimusops. Dubard (op. cit., 27) reduced Mahea to a section of Manilkara. Baehni (op. cit., 461) follows Dubard. 
Gerstner in J. S. A. Bot. 12: 49 (1946), finally, resuscitated the name Labourdonnaisia discolor Sond. In a subsequent publication in J. S. Afr. Bot. 14: 173 (1948), Gerstner pointed out that the anthers and the corolla-segments of this plant are reduced when the flowers develop in dry weather, or if the tree is not growing on fertile soil. He distinguished four formae, a forma perfecta and three progressively more depauperate forms. The most depauperate form corresponds with Mahea natalensis Pierre, so that Mahea becomes a synonym of Muriea*. Incidentally, a specimen of Wood 1134 (type number of Mahea natalensis Pierre) in BOL bears fruits and its fruits and seeds are identical with those of Muriea discolor.

The synonymy of the plant described as Mahea natalensis Pierre is also rather complicated. Engler, when he reduced Mahea natalensis to Mimusops, made the combination Mimusops natalensis (Pierre) Engl. (1904). However, Schinz had validly published as specific name Mimusops natalensis Schinz in Bull. Herb. Boiss. 4: 441 (1896) and Engler renamed this species Mimusops schinzii Engl. Under the present rules, M. natalensis (Pierre) Engl. is illegitimate, being antedated by $M$. natalensis Schinz. The first name becomes a synonym of Labourdonnaisia discolor Sond., the second of Mimusops marginata N.E. Br. [= Austromimusops marginata (N.E. Br.) A. Meeuse, quod vide, see p. 350].

My reasons for resuscitating Muriea Hartog, at least for the species Labourdonnaisia discolor Sond., are the following:

1. Labourdonnaisia was described as having 12-18 equal corolla-lobes (and not 6 lobes each with 2 lateral appendages) and 12-17 stamens, sometimes with a few staminodes, whereas Muriea has 6 corolla-lobes, each having, in perfect flowers, 2 lateral appendages, and always 12 stamens (or rarely 12 staminodes).

2. Labourdonnaisia is reported to have a large and basal seed scar, whereas Muriea has a basiventral. rather narrow seed scar. Muriea has its affinities clearly with Manilkara; it is, in fact, a Manilkara with normally $6+6$ stamens instead of 6 stamens -6 alternipetalous staminodes. Its habit is also very much that of a Manilkara (parallel substriate nervation of the leaves, etc.). However, the absence of alternipetalous staminodes distinguishes it clearly from Manilkara.

The synonymy of the only South African species, therefore, becomes as follows:-

M. discolor (Sond.) Hartog in J. Bot. 16: 145 (1878); Dubard in Ann. Mus. Col. Marseille 23: 28 (1915).

Labourdonnaisia discolor Sond. in Linnaea 23: 73 (1850); Gerstner in Jl. S. Afr. Bot. 12:49(1946), and 14: 173 (1948); Syntypes: Gueinzius 128 and Gueinzius 547 from Durban, Natal, in herb. Sonder nunc S. L. sericea Benth. et Hook. f., Gen. Pl. 2: 660, (1876), nomen.

Eichleria discolor (Sond.) Hartog in J. Bot. 16: 72 (1878).

Mimusops discolor (Sond.) Hartog in J. Bot. 17: 358 (1879); Engl., Mon. Afr. Sapot. 55, t. 34, Fig. A (1904); C. H. Wright in Dyer, Fl. Cap. 4, 1: 440 (1906).

Mahea natalensis Pierre, Notes Bot. Sapot. 10 (1890); type: probably Wood 1134 , holo in P?, also in BOL, GRA.

Mimusops natalensis (Pierre) Engl., Mon. Afr. Sapot. 65, t. 25, Fig. B (1904) non Mimusops natalensis Schinz (1896); C. H. Wright, l.c.

A medium-sized tree, 10-20 m. high with a stem diameter up to about $60 \mathrm{~cm}$. with grey, longitudinally fissured bark; on young branches the bark is smoother and of ten full of leaf-scars. Ultimate branches rather stout (at least $1.5 \mathrm{~mm}$. thick), terete.

* This reduction of the lateral appendages in one species could possibly occur in the related genus Manilkara and that is why, to my mind, the species of Gilly"s subgenus Manilkariopsis (Trop. Woods 73: 9) should be re-examined in the light of Gerstner's observations on Muriea. i.e., in relation to prevailing ecological conditions at the time of flowering. 
Innovations shortly puberulous-tomentose, the pubescence cinnamon-coloured; older parts except the lower surface of the leaf very soon glabrous. Leaves more or less distinctly crowded at the tips of the branches, rather uniform in shape, almost invariably obovate-oblong. sometimes oblong, or more or less spathulate- or lanceolate-oblong, narrowed but usually not distinctly cuneate at the base, with a rounded, obtuse, subacute or very shortly acuminate and usually recurved, almost invariably emarginate apex, green above (often drying brown or greyish-brown), densely adpressed-silvery pubescent beneath, except on the midrib, with slightly recurved margins, 3.5-7 $(-10) \mathrm{cm}$. long, $1 \cdot 5-3 \cdot 5(-4 \cdot 5) \mathrm{cm}$. wide; midrib immersed and distinctly channelled above, very prominent beneath, at first finely rusty-pubescent, ultimately glabrous and of a different colour than the silvery lower surface of the leaf (yellowish brown or dark brown when dry); secondary nerves $10-15$ or more on either side, straight, ascending at an angle of $70 e-90 e$, archingly joining near the margin, immersed but rather conspicuous above, immersed and partly hidden by the silvery tomentum below; tertiary nerves parallel to the secondary ones, usually inconspicuous below, but appearing as a fine striation above; fine ultimate nervation reticulate, usually invisible below except in the oldest leaves, but distinct and impressed above and giving the upper surface of the leaf a minutely tessellate, dull appearance. Petioles terete, hardly thickened towards the base, narrowly canaliculate above, glabrous, 6-15 mm. long. Flowers in few-flowered fascicles (often about 3 together). Perfect flowers: pedicels 5-10 mm. long, rustypubescent; flower-buds rounded at the top, broadly obovoid, $\pm 5 \mathrm{~mm}$. long and 3-4 $\mathrm{mm}$. in diameter; sepals almost completely free; the three outer ones rather coriaceous, broadly ovate, narrowed towards the tip, but not acute, $\pm 5 \mathrm{~mm}$. long and $\pm 4 \mathrm{~mm}$. wide, rusty-pubescent outside, subciliate, glabrous inside except near the apex, the inner ones narrower, $5-5.5 \mathrm{~mm}$. long and $13 \mathrm{~mm}$. wide, yellowish, whitish adpressedpubescent outside and near the apex inside; corolla white or yellowish; tube $1 \cdot 5-2 \mathrm{~mm}$. long, cylindric; the lobes long-spathulate with a long-tapering, narrow base and rounded top, the appendages broader, lanceolate-oblong or linear, acuminate, all segments $3-3.5 \mathrm{~mm}$. long; filaments $2-2.5 \mathrm{~mm}$. long, filiform and slender; anthers $1.5-2 \mathrm{~mm}$. long, ovate-cordate, apiculate; ovary depressed-conical, $\pm 1 \mathrm{~mm}$. high and $\pm 1 \mathrm{~mm}$. in diameter, densely sericeous-pilose; style glabrous cylindric, 3-3.5 mm. long, rather gradually tapering into the flat, subcapitate and \pm 6 -lobed stigma. Imperfect flowers on short pedicels (sometimes under $5 \mathrm{~mm}$. long), often considerably smaller (e.g., calyx and corolla lobes only $2 \mathrm{~mm}$. long); corolla lobes with reduced lateral appendages, trifid, tridentate or entire; anthers very small or wanting or sometimes developed, ovary and style as above but sometimes ovary more subglobose and style only $\pm 2 \mathrm{~mm}$. long. Fruit spherical, edible and red when ripe, according to Gerstner (1946), but when dried ellipsoid, 8-12 $\mathrm{mm}$. long and 5-10 $\mathrm{mm}$. wide, crowned by the peristent style. Fruiting pedicels not appreciably lengthened or incrassate; fruiting calyx adpressed to the fruit. Seed elliptic in outline, compressed, $\pm 8 \mathrm{~mm}$. long, $\pm 5 \mathrm{~mm}$. wide, and $+3.5 \mathrm{~mm}$. thick in the middle; scar basilateral, oval or elliptic, $3-4 \mathrm{~mm}$. long, and 1-2 mm. wide in the widest place; testa pale fawn-coloured when dry, thin and brittle.

Distribution.-Natal, from Durban northwards, Zululand, Swaziland, P.E. Africa and extending into East Tropical Africa.

Natal.-Durban: Thorns s.n. (NH No. 40612, PRE); Durban, Albert Park, $V a n$ der Byl s.n. (HN No. 16245 and 16246 in NH, GRA); Gerstner 4703 (PRE), Butcher (= Gerstner 4712) (PRE, SRGH); Gerstner 6820 (NBG, PRE). Pinetown: Umzinyati, Wood 11440 (PRE, NU, J). Ndwedwe: Inanda, Wood 1134 [GRA, BOL, one of the numbers cited by Engler sub. Mimusops natalensis (Pierre) Engl.], 1349 (NH, BOL, SAM). Palmiet, Wood 8378 (NH, NU, PRE). Lower Tugela: Darnal, Schmidt 39, 40 (NH). Hlabisa: near Hlabisa, Gerstner 4117 (NH, PRE) 4527 (PRE); Emgangado, Gerstner 5077 (RE, BOL, NBG); Hluhluwe Game Reserve, Ward 2639 
(NH, PRE), "Zululand "; Gerstner 2539 (BOL). Ubombo: Bangazi Lake, Boocock FD herb. No. 5720 (PRE, SAFD). Swaziland (?): Mangusi Forest (prob. near Hlatikulu) FD. Herb. No. 5314 (PRE, SAFD).

Portuguese East Africa.-Sul do Save: Maputo, Sim 20992 (NU, PRE); Lourenço Marques: Oliveira 74 (LM); Inhaca Island, Mrs. Moss (J. No. 27637, also PRE) between Chongoene and Chidinguel: Pedro 247 (PRE); Chibuto e Vila Gomez da Costa, Pedro \& Pedrogão 1559 (PRE). "Zavala Distr.," Afr. Music Res. Libr. III (PRE); Inhambane, Gomes e Sousa 1657 (PRE, COI), 1949 (COI); Inhambane, Maxixe, Amostra 1 (LM). Manica e Sofala: Macuacua, Simão 1251 (PRE); Gazaland, Earthy 27 (PRE); Masiyeni, Earthy 169 (PRE). Niassa: Porto Amelia, Barbosa 1865 (LM), Barbosa \& Lemos 2031 (PRE); entre Pundankas e Nanga, Barbosa 2190 (PRE).

Southern Rhodesia.-Umtali: Chase 4664, 4559, 5722, Ball 1 (PRE, SRGH).

As this species is most probably found in other parts of tropical East Africa, it is not unlikely that it was described from this area under a different name. It is quite likely that Engler's species Mimusops buchananii in Pflanzenw. O. Afr., C, 307 (1895) and in Mon. Sapot. Afr. 56, t. 19, Fig. B (1904) and Mimusops altissima Engl., op. cit. (1904), 55, are referable to this species. These two have 12 stamens and the descriptions (and Figure of $\boldsymbol{M}$. buchananii) agree very well indeed. This would extend the range of Muriea discolor to Nyasaland and Tanganyika. 